口 KLAUDIJA ŠTERMAN IVANČIČ (UR.)

\title{
IZHODIŠČCA MERJENJA MATEMATIČNE PISMENOSTI V RAZISKAVI PISA 2012 S PRIMERI NALOG
}

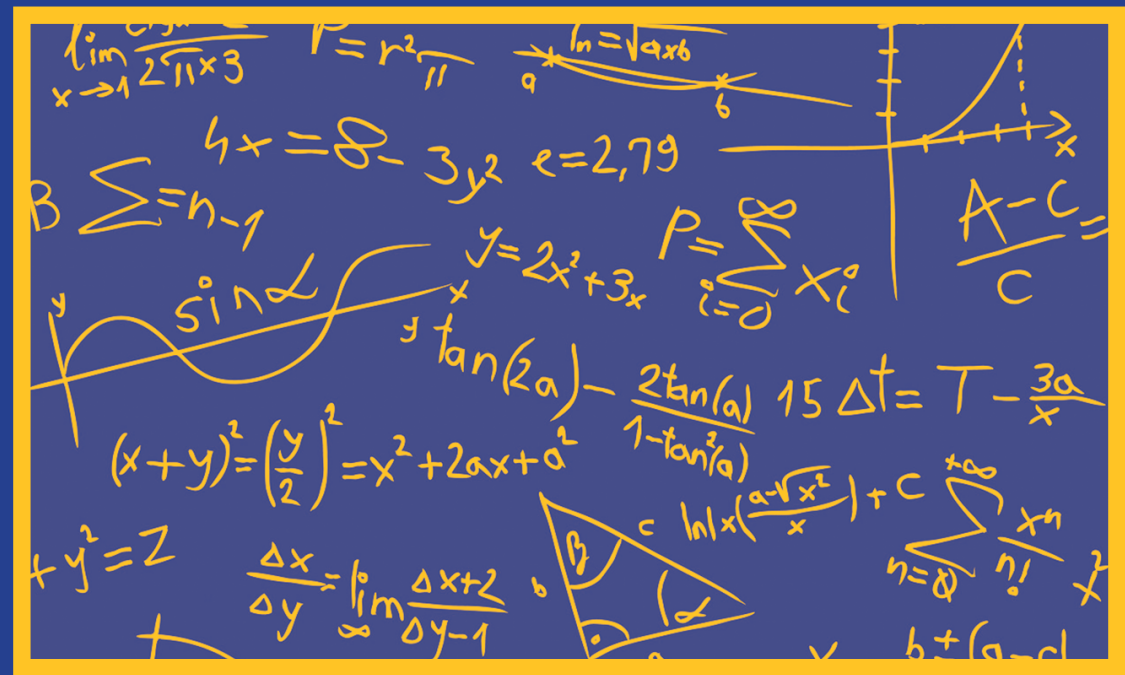

DIGITALNA KNJIŽNICA • DOCUMENTA • 7 

IZHODIŠČA MERJENJA — 


\section{口ob}


- KLAUDIJA ŠTERMAN IVANČIČ (UR.)

\section{IZHODIŠČC MERJENJA MATEMATIČNE PISMENOSTI V RAZISKAVI PISA 2012 $S$ PRIMERI NALOG}


Klaudija Šterman Ivančič (ur.)

Izhodišča merjenja matematične pismenosti v raziskavi PISA 2012 s primeri nalog strokovna monografija

Digitalna knjižnica

Uredniški odbor: Igor Ž. Žagar (Educational Research Institute \& University of Primorska),

Jonatan Vinkler (University of Primorska), Janja Žmavc (Educational Research Institute),

Alenka Gril (Educational Research Institute)

Zbirka: Documenta, 7

Glavni in odgovorni urednik: Igor Ž. Žagar

Urednica zbirke: Alenka Gril

Recenzenta: Andreja Drobnič Vidic, Zlatan Magajna

Prevod izhodišč: Mateja Petan, Klaudija Šterman Ivančič

Prevod nalog iz matematične pismenosti: Miranda Bobnar, Karmen Dobrila, Lorena Dobrila, Karmen Filipič, Daša Perme Jurjavčič, Polona Pečovnik Kopač, Barbara Müller, Mateja Petan, Barbara Pogačnik

Tehnični urednik, oblikovanje, prelom in digitalizacija: Jonatan Vinkler

Lektor: Davorin Dukič

Založnik: Pedagoški inštitut

Gerbičeva 62, SI-1000 Ljubljana

Ljubljana 2013

Za založnika: Mojca Štraus

ISBN 978-961-270-200-7 (pdf)

http://www.pei.si/ISBN/978-961-270-200-7.pdf

ISBN 978-961-270-199-4 (html)

http://www.pei.si/ISBN/978-961-270-199-4/index.htm

DOl: https://www.doi.org/10.32320/978-961-270-200-7

(c) 2013 Pedagoški inštitut/Educational Research Institute

Publikacija je nastala v okviru projekta Ugotavljanje in zagotavljanje kakovosti v izobraževanju in usposabljanju - Evalvacija vzgoje in izobraževanja na podlagi mednarodno priznanih metodologij ki ga sofinancirata Evropski socialni sklad Evropske unije in Ministrstvo za izobraževanje, znanost in šport Republike Slovenije.

Izvirnik je v angleščini objavil OECD pod naslovom: OECD (2013), PISA 2012 Assessment and Analytical Framework: Mathematics, Reading, Science, Problem Solving and Financial Literacy, PISA, OECD Publishing, http://dx.doi.org/10.1787/9789264190511-en @ 2013 OECD, vse pravice pridržane. @ 2013 Pedagoški inštitut, Slovenija, za slovensko izdajo. Za kakovost in usklajenost slovenskega prevoda z izvirnikom odgovarja Pedagoški inštitut. V primeru kakršnega koli odstopanja prevoda od izvirnika se upošteva izvirnik.

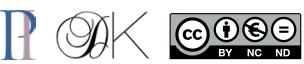

CIP - Kataložni zapis o publikaciii

knjižnica, Ljubljana

37.091.26:51(0.034.2)

IZHODIŠČA merienja matematične pismenostiv raziskavi PISA 2012 s primeri nalog [Elektronskivir] · strokovna monografija / Klaudija Šterman Ivančič (ur) · prevod Mateja Petan - [et al] - El. knijga - Ljubljana : Pedagoški inšstitut, 2013. - (Digitalna knjižnica. Documenta ; 7)

Način dostopa (URL): https://www.pei.si/ISBN/izhodisca-merjenja-matematicne-pismenosti-v-raziskavi-pisa-2012-s-primeri-nalog/

ISBN 978-961-270-199-4 (html)

1 Sterman lvančičc Klaudija

270442752 


\section{Vsebina}

Kazalo tabel in slik 11

Predgovor 13

Predstavitev raziskave PISA $2012 \quad 15$

Organizacijske značilnosti raziskave PISA na mednarodni ravni 15

Raziskava PISA na nacionalni ravni 17

Znanje iz matematike, ki ga z raziskavo PISA 2012 ugotavljamo 19

Zajem podatkov in poročanje o rezultatih v raziskavi PISA $2012 \quad 21$

Lestvica matematične pismenosti 23

Opredelitev matematične pismenosti $\quad 27$

PISA 2012: dijaki kot aktivni reševalci problemov 28

PISA 2012: uporaba raznolikih kontekstov pri reševanju problemov 31

PISA 2012: vidna vloga matematičnih orodij in tehnologije 31

Vidiki matematične pismenosti $\quad 33$

Matematične vsebine $\quad 34$

Spremenljivke in odnosi 36

Liki in telesa $\quad 37$

$\begin{array}{ll}\text { Količine } & 37\end{array}$ 
Verjetnost in delo s podatki 38

Vsebine matematične pismenosti bolj podrobno 39

Matematični procesi $\quad 40$

Matematično formuliranje situacij $\quad 41$

Uporaba matematičnih konceptov, dejstev, postopkov in sklepanj 42

Interpretiranje, uporaba in evalviranje matematičnih rezultatov 43

Osnovne matematične kompetence, na katerih temeljijo matematični procesi 44

Osnovne matematične kompetence in njihovo razmerje do zahtevnosti nalog $\quad 48$

Sporočanje 48

Matematiziranje 49

Predstavljanje 49

Sklepanje in utemeljevanje $\quad 49$

Oblikovanje strategij 50

Uporaba simbolnega, formalnega in tehniškega jezika in operacij 50

Uporaba matematičnih orodij 50

Matematični konteksti 51

Porazdelitev nalog glede na vsebino, proces in kontekst 53

Porazdelitev nalog glede na vsebinske kategorije 53

Porazdelitev nalog glede na matematične procese 54

Porazdelitev nalog glede na kontekstualne kategorije 54

Vprašalniki za dijakinje in dijake $\mathbf{5 5}$

Zanimanje za matematiko in odnos do matematičnih vsebin 56

Naloge iz matematične pismenosti $\quad 59$

USB KLJUČ $\quad 60$

PREDVAJALNIKI Z NAPAKO

NAKUP STANOVANJA

PRODAJALNA SLADOLEDA 


\begin{tabular}{|c|c|}
\hline NAFTNI MADEŽ & 77 \\
\hline PRETOK INFUZIJE & 79 \\
\hline $\mathrm{MP}_{3}$ PREDVAJALNIKI & 82 \\
\hline LESTVICE & 86 \\
\hline PINGVINI & 90 \\
\hline VETRNA ENERGIJA & 95 \\
\hline OMAKA & 106 \\
\hline FERRISOVO KOLO & 107 \\
\hline ZLAGANJE KOCK & 109 \\
\hline VZPON NA GORO FUDŽI & 111 \\
\hline KOLESARKA HELENA & 115 \\
\hline POČITNIŠKO STANOVANJE & 119 \\
\hline IZPOSOJA DVD-JEV & 122 \\
\hline KABELSKA TELEVIZIJA & 125 \\
\hline KATERI AVTO IZBRATI? & 129 \\
\hline GARAŽA & 133 \\
\hline PRODAJANJE ČASOPISOV & 137 \\
\hline VRTLJIVA VRATA & 142 \\
\hline Povzetek & 147 \\
\hline Summary & 149 \\
\hline Literatura & 151 \\
\hline Imensko in stvarno kazalo & 153 \\
\hline
\end{tabular}





\section{Kazalo tabel in slik}

Tabela 1: Časovni potek raziskave PISA 2012 na šolah 21

Tabela 2: Opis ravni matematične pismenosti 24

Tabela 3: Porazdelitev matematičnih nalog glede na vsebinske kategorije 53

Tabela 4: Porazdelitev matematičnih nalog glede na matematične procese $\quad 54$

Tabela 5: Porazdelitev matematičnih nalog glede na kontekstualne kategorije $\quad 54$

Slika 1: Organizacijska struktura delovnih teles v raziskavi PISA $2012 \quad 16$

Slika 2: Lestvica matematičnih dosežkov 23

Slika 3: Model matematične pismenosti v praksi 29

Slika 4: Sedem osnovnih matematičnih kompetenc v okviru treh kategorij procesov $\quad 4^{8}$ 



\section{Predgovor}

Raziskava PISA je zasnovana kot dolgoročen mednarodni projekt, ki se pod okriljem organizacije OECD od leta 2000 izvaja na mednarodni ravni v triletnih ciklih. Slovenija se je v projekt vključila leta 2004, ko so se pričele priprave na glavni zajem podatkov v letu 2006. V raziskavi PISA 2012 je poleg Slovenije sodelovalo 66 držav, izmed tega 33 držav članic OECD in 33 držav partnerk. Glavni cilj raziskave je bil tudi tokrat ugotavljanje kompetenc Is-letnikov iz naravoslovne, matematične in bralne pismenosti, tokrat s poudarkom na matematični pismenosti.

Slovenija je v ciklu raziskave PISA 2012 prvič sodelovala pri ugotavljanju matematične pismenosti kot poudarjenem področju. To pomeni, da so kar dve tretjini nalog v testu PISA predstavljale matematične naloge in so bile bralne ter naravoslovne naloge $\mathrm{v}$ manjšini. Pedagoški inštitut je v letu 2008 (ur. Repež et al., 2008) že izdal izhodišča merjenja matematične pismenosti, ki so se navezovala na naloge iz cikla 2003, kjer je bila poudarjeno področje merjenja prav tako matematika in v katerem Slovenija še ni sodelovala. Če primerjamo izhodišča merjenja iz let 2003 in 20I2, opazimo marsikatero spremembo, predvsem $\mathrm{v}$ pojmovanju matematičnih vsebin in kompetenc, ki so med drugim prilagojene spretnostim Is-letnikov, ki jih od njih zahteva današnje, hitro spreminjajoče se okolje.

Raziskava PISA 2012 se na nacionalni ravni od preteklih ciklov razlikuje tudi po tem, da je Slovenija prvič sodelovala v t. i. računalniškem preverjanju znanja matematike, branja in problemsko zasnovanih nalog. Vsi sodelujoči dijaki v raziskavi so tako najprej sodelovali v raziskavi tipa »papir in svinčnik «, kjer so naloge reševali v delovnih zvezkih, kasneje pa je podvzorec dijakov sodeloval še v reševanju nalog na računalnikih.

Pričujoča izhodišča merjenja matematične pismenosti se navezujejo izključno na naloge, ki so jih dijaki reševali v delovnih zvezkih, saj so izhodišča merjenja matematične pi- 
smenosti za računalniško zasnovane naloge popolnoma drugačna in obravnavajo drugo vrsto kompetenc.

Publikacija, ki je pred vami, je namenjena vsem osnovnošolskim in srednješolskim učiteljem, učencem in dijakom ter vsem strokovnjakom, ki vas predstavljeno področje pri vašem raziskovalnem delu zanima. Predvsem pa upamo, da bodo objavljene naloge v učni praksi pogosto uporabljen vir pri razvijanju uporabe pri pouku usvojenega znanja v konkretnih, življenjskih situacijah.

Urednica 


\section{Predstavitev raziskave PISA 2012}

\section{Organizacijske značilnosti raziskave PISA na mednarodni ravni}

Sodelovanje velikega števila držav v mednarodni primerjalni raziskavi predstavlja zahtevno koordinacijo projekta in natančno določanje postopkov izvedbe, ki jim morajo slediti vse udeležene države. Tako deluje na mednarodni ravni več različnih delovnih teles, od katerih nekatera skrbijo za vsebinska vprašanja, druga pa so bolj osredotočena na samo izvedbo raziskave. Organizacijska struktura raziskave je nazorno prikazana na Sliki I (ur. Štraus, 2008), v nadaljevanju pa jo tudi na kratko opisujemo.

a) Sekretariat OECD

Sekretariat OECD s sedežem v Parizu je odgovoren za vodenje projekta PISA v celoti.

b) Mednarodni svet raziskave PISA - PGB

Mednarodni svet raziskave PISA - PISA Governing Board (PGB) nadzira in oblikuje izhodišča projekta in je sestavljen iz predstavnikov držav članic OECD in držav partnerk. PGB ima vodilno vlogo pri sprejemanju odločitev o konceptualni zasnovi raziskave PISA, določanju okvira zajemanja podatkov na področju merjenja znanja, smernicah nadaljnjega poteka raziskave, določanju glavnih korakov pri izvajanju raziskave, določanju in sprejemanju standardov izvedbe in načinov poročanja v raziskavi, odločanju o zasnovi mednarodnih poročil in interpretacij rezultatov raziskave, izvajanju razpisov za pripravo tematskih poročil o posebnih raziskovalnih področjih v raziskavi PISA ter odločanju o izboru prijaviteljev na razpise za sodelovanje v raziskavi. 


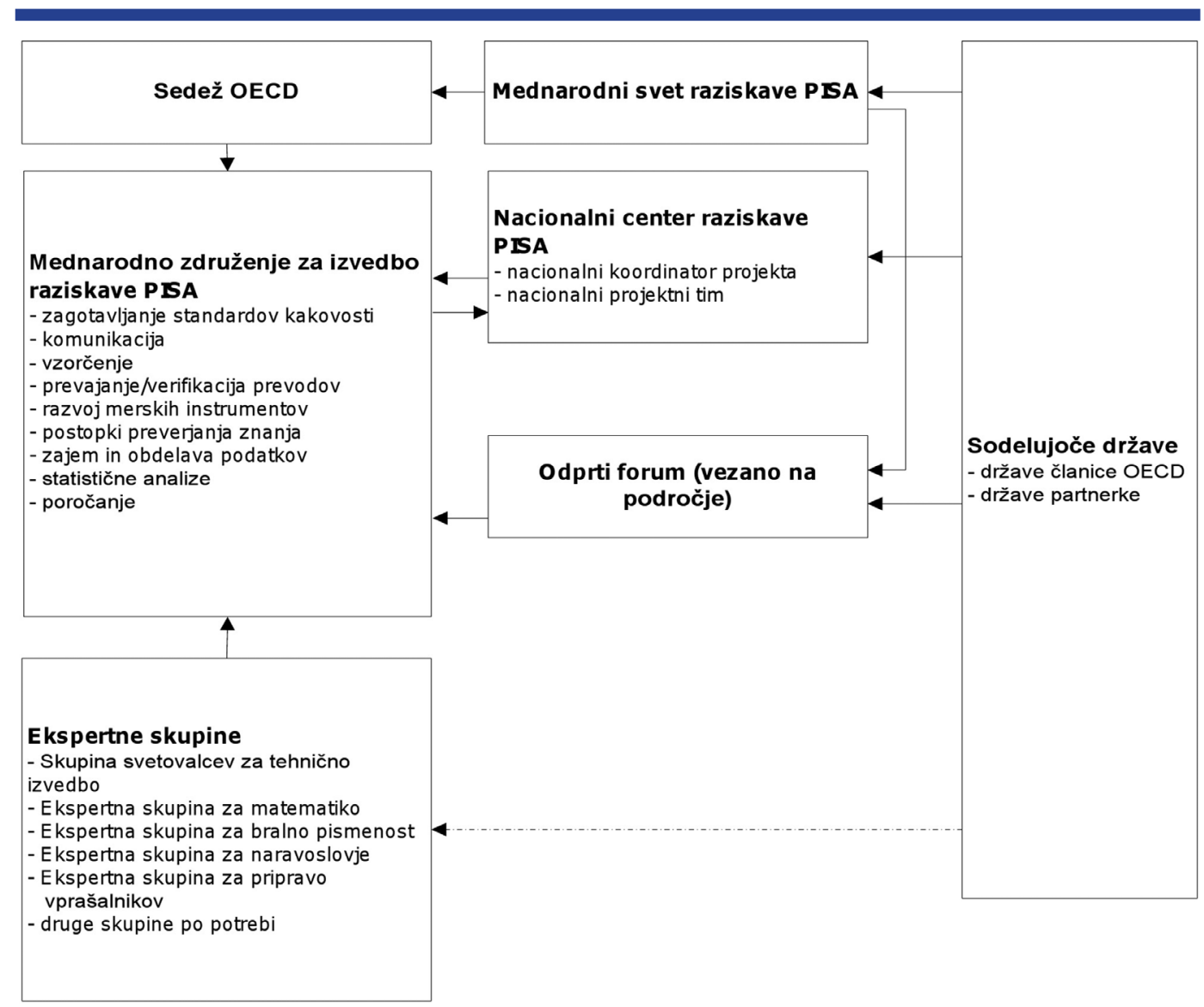

Slika ı: Organizacijska struktura delovnih teles v raziskavi PISA 2012

c) Mednarodno združenje organizacij

Mednarodno združenje organizacij je sestavljeno iz ıo organizacij, od katerih je imela v raziskavi PISA 2012 vodilno vlogo organizacija ACER (Australian Council for Educational Research). Ostale organizacije so naslednje: cApStAn Linguistic Quality Control, DIPF (Deutches Institut für Internationale Pädagogische Forschung), NIER Japan (National Institute for Educational Policy Research), aSPe (Unité d'analyse des systèmes et des pratique d'enseignement), Westat, ETS (Educational Testing Service), ILS (Institutt for Laererutdanning of Skoleforskning), IPN (Leibniz-Institute for Science and Mathemati- 
cs Education), NIER (National Institute for Educational Policy Research) in (CRP) Henri Tudor and Universite de Luxembourg (EMACS).

Naloga mednarodnega združenja organizacij je nadziranje razvoja in oblikovanje merskih inštrumentov (nalog in vprašalnikov) ter postopkov vzorčenja, prevajanje/verifikacija gradiv, oblikovanje postopkov preverjanja znanja na terenu, nadzor zajema in obdelave podatkov, statistične analize ter poročanje rezultatov. Veliko časa namenijo tudi spodbujanju odprte in učinkovite komunikacije med vsemi udeleženci v projektu ter tesnemu sodelovanju s predstavniki nacionalnih centrov. Skrbijo tudi za nenehno strokovno izobraževanje zaposlenih v nacionalnih centrih, zaradi lažjega uvajanja novosti, ki jih prinaša vsak posamezen cikel raziskave.

Posebno vlogo pa imajo v raziskavi PISA tudi različne ekspertne skupine, ki so ustanovljene z namenom neodvisnega svetovanja. Naj omenimo le nekatere:

d) Skupina svetovalcev za tehnično izvedbo raziskave - TAG (Technical Advisory Group)

Ta skupina svetuje pri tehničnih posebnostih, kot je na primer metodologija vzorčenja, poseben poudarek pa namenja zagotavljanju tehnično brezhibnih podatkov, zbranih $\mathrm{v}$ raziskavi.

e) Ekspertne skupine za posamezna področja merjenja

Za pripravo predlogov okvirov merjenja znanja posameznih področij pismenosti in zbiranje in pripravo predlogov nalog v mednarodnih preizkusih znanja delujejo Ekspertna skupina za bralno pismenost (Reading Expert Group, REG), Ekspertna skupina za matematiko (Mathematics Expert Group, MEG) in Ekspertna skupina za naravoslovje (Science Expert Group, $S E G$ ). Za pripravo predlogov vprašanj v mednarodnih vprašalnikih za zajemanje podatkov o spremljajočih dejavnikih, deluje Ekspertna skupina za pripravo vprašalnikov (Questionnaire Expert Group, QEG).

$\mathrm{V}$ posameznem ciklu raziskave PISA so ustanovljeni tudi različni forumi, kjer imajo strokovnjaki iz posameznih sodelujočih držav možnost zagovarjati interese in poglede svoje države pri nastajanju teoretičnih podlag (izhodišč) raziskave in razvoju inštrumentov merjenja.

\section{Raziskava PISA na nacionalni ravni}

Ministrstvo za šolstvo in šport je tudi v tem ciklu raziskave PISA naročnik in financer le-te (skrbnik pogodbe med OECD in Slovenijo), Slovenijo pa zastopa tudi v Mednarodnem svetu raziskave. Odgovornost za izvedbo raziskave v Sloveniji nosi Nacionalni cen- 
ter raziskave PISA iz Pedagoškega inštituta v Ljubljani. Za samo implementacijo raziskave je znotraj omenjenega centra odgovoren t. i. nacionalni koordinator raziskave - NPM (National Project Manager). Naloga nacionalnega centra je, da seznanja organizacije na mednarodni ravni s pogoji in ovirami pri izvedbi raziskave na nacionalni ravni, daje povratne informacije o razvojnih rešitvah in svetuje, na kakšen način bi raziskavo v določeni državi najbolje izvedli. Predvsem pa mora čim natančneje in skladno z mednarodno metodologijo, terminskim načrtom in standardi zagotoviti zanesljive podatke o dosežkih dijakov v posamezni državi.

Pri izvedbi raziskave PISA imajo pomembno vlogo tudi ravnatelji šol, ki samo izvedbo podpirajo in ustvarijo pogoje, da lahko le-ta steče, obenem pa aktivno sodelujejo pri izpolnjevanju »Vprašalnika za šolo «. Vsak izmed ravnateljev določi koordinatorja na šoli, ki z nacionalnim centrom ves čas priprav na izvedbo tesno sodeluje. Njegova vloga je ključna pri zagotavljanju kvalitetne izvedbe raziskave na šoli in predstavlja nekakšen vezni člen med dijaki, ki jih dobro pozna, ter izvajalcem, ki samo testiranje na šoli izvede.

Koordinator opravi vrsto nalog, ki jih moramo za uspešno izvedbo raziskave na šoli skupaj izvesti. Njegove najpomembnejše naloge so naslednje:

- na roditeljskih sestankih obvesti starše, da je šola udeležena v mednarodni raziskavi PISA,

- $\quad$ pripravi seznam dijakov, ki ustrezajo kriterijem ciljne populacije, in ga posreduje nacionalnemu centru,

- $\quad$ obvesti dijake, ki so izbrani za sodelovanje v raziskavi, o pomembnosti raziskave in njihovega sodelovanja ter jih motivira za sodelovanje,

- uskladi datume izvedbe raziskave na šoli z nacionalnim centrom,

- $\quad$ priskrbi ustrezen prostor za izvedbo raziskave na šoli in uskladi druge načrtovane dejavnosti za nemoteno šolsko delo,

- $\quad$ sodeluje z izvajalcem, sodelavcem PI, ki izvedbo na šoli izpelje, in mu pri sami izvedbi po potrebi pomaga,

- $\quad$ v primeru nadzora izvedbe na šoli sprejme nadzornika oz. sodelavca PI in mu posreduje potrebne informacije.

Poleg omenjenih sodelavcev v raziskavi, pa ne smemo pozabiti še pomembne vloge mnogih drugih, kot na primer izvajalcev na šolah, koderjev odgovorov odprtega tipa, koderjev poklicev, vnašalcev podatkov ter nadzornikov izvedb. Vsak izmed njih prispeva svoj delček v mozaiku del, ki jih je potrebno opraviti, da bi zagotovili kvalitetne nacionalne podatke. 
Osnovno in ključno vlogo pa imajo pri celotni izvedbi seveda dijaki ter njihovi starši, ki so v raziskavi pripravljeni sodelovati in brez katerih primerljivih rezultatov za Slovenijo ne bi bilo.

\section{Znanje iz matematike, ki ga z raziskavo PISA 2012 ugotavljamo}

$\mathrm{Z}$ raziskavo PISA ne ugotavljamo kurikularnih znanj, ampak skušamo ugotavljati, kako dobro so mladi ob zaključku obveznega šolanja pripravljeni na izzive v sodobni družbi. Osredotočamo se na ugotavljanje zmožnosti mladih, da uporabijo znanje v resničnem življenju, in ne toliko na ugotavljanje znanj, ki si jih učenci pridobijo pri posameznih učnih predmetih, in znanj, ki jih predpisuje šolski kurikulum. Poglavitni cilj je ugotoviti, kako dobro zmorejo učenci tovrstno znanje, ki so si ga pridobili skozi najrazličnejše načine, uporabiti v različnih življenjskih, problemsko zasnovanih situacijah. Torej tudi v situacijah, s katerimi se bodo dejansko srečevali v poznejšem, vsakdanjem življenju.

Med drugim so razlogi za to, da znanje, ki ga v raziskavi PISA ugotavljamo, ni in tudi ne more biti vezano izključno na šolski kurikulum sodelujoče države, naslednji:

- čeprav je pridobivanje specifičnega znanja pri šolskem učenju pomembno, se sama uporaba ter uporabna vrednost tovrstnega znanja skozi življenje spreminja. Ko se na primer danes soočamo z različnimi problematikami družbe, je v naravoslovju specifično znanje, kot je poznavanje imen rastlin in živali, pogosto manj pomembno kot razumevanje širših pojmov, kot so poraba energije, načini zaščite okolja in človekovo zdravje. Pri branju postanejo pomembne spretnosti, kot sta interpretacija pisnega gradiva ter uporaba prebrane vsebine. Pri matematiki pa se pomembnejša kot to, da zna posameznik odgovoriti na značilna vprašanja iz učbenika, pogosto izkaže zmožnost, da zna sklepati in razumeti odnose in odvisnost pojavov;

- $\quad$ če bi se v mednarodnem okolju osredotočili izključno na kurikularno vsebino posamezne države, bi s tem zanemarili kurikularne elemente drugih držav in tudi elemente, ki so morda skupni vključenim državam;

- nekatere širše in splošnejše spretnosti, kot so komunikacija, prilagodljivost, fleksibilnost in reševanje problemov ter uporaba informacijskih tehnologij, so nujne za razvoj učencev. Te spretnosti se razvijajo prek kurikulov pri več predmetih in medkurikularno. Zajem podatkov o teh spretnostih zato zahteva široko, medkurikularno pozornost (OECD, 2006). 
Matematična pismenost se v raziskavi PISA 2012 nanaša na učenčevo zmožnost prepoznavanja in razumevanja vloge, ki jo ima matematika v svetu, na zmožnost sprejemanja dobro utemeljenih odločitev in uporabo matematike na načine, ki ustrezajo potrebam posameznikovega življenja v vsakdanjih situacijah. To pomeni, da se nanaša na zmožnost učencev, da učinkovito utemeljujejo in posredujejo svoje zamisli, ko oblikujejo, rešujejo in interpretirajo rešitve matematičnih problemov v različnih situacijah. Kot taka matematična pismenost zajema učenčevo obvladovanje:

- Matematičnih vsebin, ki so predstavljene s štirimi vsebinskimi sklopi: spremenljivkami in odnosi (npr. funkcije, enačbe, tabelarične in grafične predstavitve ter prenos teh konceptov $\mathrm{v}$ realne situacije, kot so npr. rast organizmov, glasba, spreminjanje letnih časov, stopnje brezposelnosti, ekonomski pogoji ipd.), liki in telesi (npr. geometrija, merjenje, vizualizacija ter prenos teh konceptov v situacije, kot so predstavljanje objektov, navigacija, prepoznavanje vzorcev ipd.), količinami (razumevanje mer, enot, relativne velikosti, ocenjevanje vrednosti ipd.) ter verjetnostjo in delom s podatki (interpretacija in oblikovanje zaključkov v situacijah, kjer je treba upoštevati verjetnost dogodkov ipd.).

- Matematičnih procesov, ki so predstavljeni s splošnimi matematičnimi kompetencami, kot so formuliranje, uporaba in interpretiranje. V nalogah preizkusov znanja raziskave PISA te spretnosti niso medsebojno izključujoče, saj velja, da je za reševanje katere koli matematične naloge potrebnih več kompetenc. Naloge in vprašanja so zato organizirani po skupinah kompetenc, ki opredeljujejo tip razmišljanja in spretnosti, ki so za rešitev določenega problema potrebne.

- Matematičnib kontekstov, v katerih se uporablja matematika, in sicer glede na njihovo neposredno povezanost z učenci. Opredeljeni so štirje konteksti: družbeni, poklicni, osebni in znanstveni.

Matematične vsebine, procese in koncepte podrobneje predstavljamo v nadaljevanju na strani 20. 


\section{Zajem podatkov in poročanje o rezultatih $v$ raziskavi PISA 2012}

Matematično pismenost smo znotraj raziskave z nalogami tipa »papir in svinčnik« tudi tokrat preverjali s pomočjo delovnih zvezkov, ozadje dijakovih dosežkov pa s spremljajočimi vprašalniki.

Preizkus z nalogami tipa »papir in svinčnik « je na šolah potekal 3 ure in 20 minut, in sicer po sledečem urniku:

Tabela r: Časovni potek raziskave PISA 20 rz na šolah

\begin{tabular}{|l|l|}
\hline Dejavnost & Čas \\
\hline Razdelitev gradiva in branje splošnih navodil & IO-I5 minut (približno) \\
\hline Reševanje delovnega zvezka & I ura (točno) \\
\hline Kratek odmor & 5 minut (največ) \\
\hline Reševanje delovnega zvezka & I ura (točno) \\
\hline Kratek vprašalnik na koncu delovnega zvezka & 5 minut (največ) \\
\hline Odmor & I5 minut \\
\hline Vprašalnik za dijakinje in dijake & 35 minut (približno) \\
\hline Zbiranje gradiva ob koncu izvedbe & $3-5$ minut (približno) \\
\hline Skupaj & 3 ure in 2o minut (približno) \\
\hline
\end{tabular}

Delovni zvezki so vključevali različne tipe nalog oziroma vprašanj. Nekatera so od učencev zahtevala, da izberejo oziroma napišejo kratek odgovor, ki ga lahko neposredno primerjamo z edinim pravilnim odgovorom. Sem sodijo tudi vprašanja izbirnega tipa ali 
vprašanja zaprtega tipa. Ta vprašanja imajo ali pravilen ali nepravilen odgovor in pogosto merijo manj zahtevne spretnosti. Druga vprašanja so od učencev zahtevala, da razvijejo in napišejo nekoliko daljši odgovor, kar omogoča merjenje širšega znanja in spretnosti. Pri teh vprašanjih je razpon sprejemljivih odgovorov širši, vrednotenje oziroma kodiranje pa je bolj zapleteno in lahko vsebuje tudi kode za delno pravilne odgovore (ur. Maša Repež, 2008).

Dijakom je bilo omogočeno, da so pri reševanju nalog tipa »papir in svinčnik« uporabljali računala, tako kot sicer pri pouku v šoli. To predstavlja najbolj avtentično ugotavljanje dijakovih dosežkov in najbolj informativno primerjavo dosežkov izobraževalnih sistemov. Leta 2012 so bile pri ugotavljanju matematične pismenosti v raziskavi PISA nekatere naloge prvič zasnovane samo za reševanje v delovnih zvezkih in so dijaki s pomočjo računal zahtevane izračune najverjetneje opravili hitreje in laže.

Enako kot v preteklih ciklih tudi v raziskavi PISA 2012 posamezen dijak ni reševal vseh nalog. Naloge s področja matematike, branja in naravoslovja so bile razdeljene v $\mathrm{I} 3$ sklopov ( 7 matematičnih, 3 naravoslovne in 3 bralne), vsak delovni zvezek pa je zajemal 4 sklope. Za vsak skop se je predvidelo 30 minut reševanja. V vsakem delovnem zvezku je bil vsaj en sklop matematičnih nalog.

Naloge v raziskavi PISA 2012 so sestavljene iz uvodnega besedila (vezano besedilo, tabela, graf ipd.), ki mu sledi določeno število vprašanj, povezanih z uvodnim besedilom. Ta pristop dopušča bolj poglobljena vprašanja, kot če bi se vsako vprašanje navezovalo na novo vsebino. Taka postavitev nalog učencem omogoča, da se poglobijo v gradivo, s katerim nato lahko merimo različne vidike znanja in spretnosti (ur. Maša Repež, 2008).

Naloge, ki so bile izbrane in vključene v raziskavo PISA, zajemajo široko paleto zahtevnosti, katere namen je približati se raznovrstnim sposobnostim in zmožnostim dijakov, ki sodelujejo v raziskavi. Pri tem so vse glavne kategorije ugotavljanja matematične pismenosti (vsebinski sklopi, procesni sklopi in kontekstualne kategorije) predstavljene v obliki nalog različnih zahtevnostnih stopenj. Naloge, ki so bile izbrane in vključene v raziskovalni inštrumentarij, temeljijo na ujemanju z izhodiščnimi kategorijami in njihovimi merskimi značilnostmi.

Poleg tega je bila raven branja, ki je zahtevana, da bi dijaki lahko uspešno reševali naloge, dobro premišljena $\mathrm{v}$ času razvijanja in izbiranja nalog. Naloge so bile razvite tako, da bi bilo besedilo čim bolj preprosto in neposredno. Prav tako so strokovnjaki pazili, da so se $\mathrm{v}$ nalogah izognili tistim kontekstom, ki bi lahko povzročili pristranskost na kulturnem področju, zato so izbor preverili z nacionalnimi izvajalci raziskave. Tudi prevajanje 
nalog v številne jezike je bilo izvedeno pazljivo, upoštevaje povratno prevajanje in druge protokole.

Dosežke dijakov na posameznih nalogah v raziskavi PISA uvrščamo na t. i. lestvico matematične pismenosti (glej sliko 2), s povprečjem 494 točk in standardnim odklonom 92 za vsa tri merjena področja. To pomeni, da dve tretjini učencev v državah OECD dosegata rezultat med 402 in 586 točkami.

\section{Lestvica matematične pismenosti}

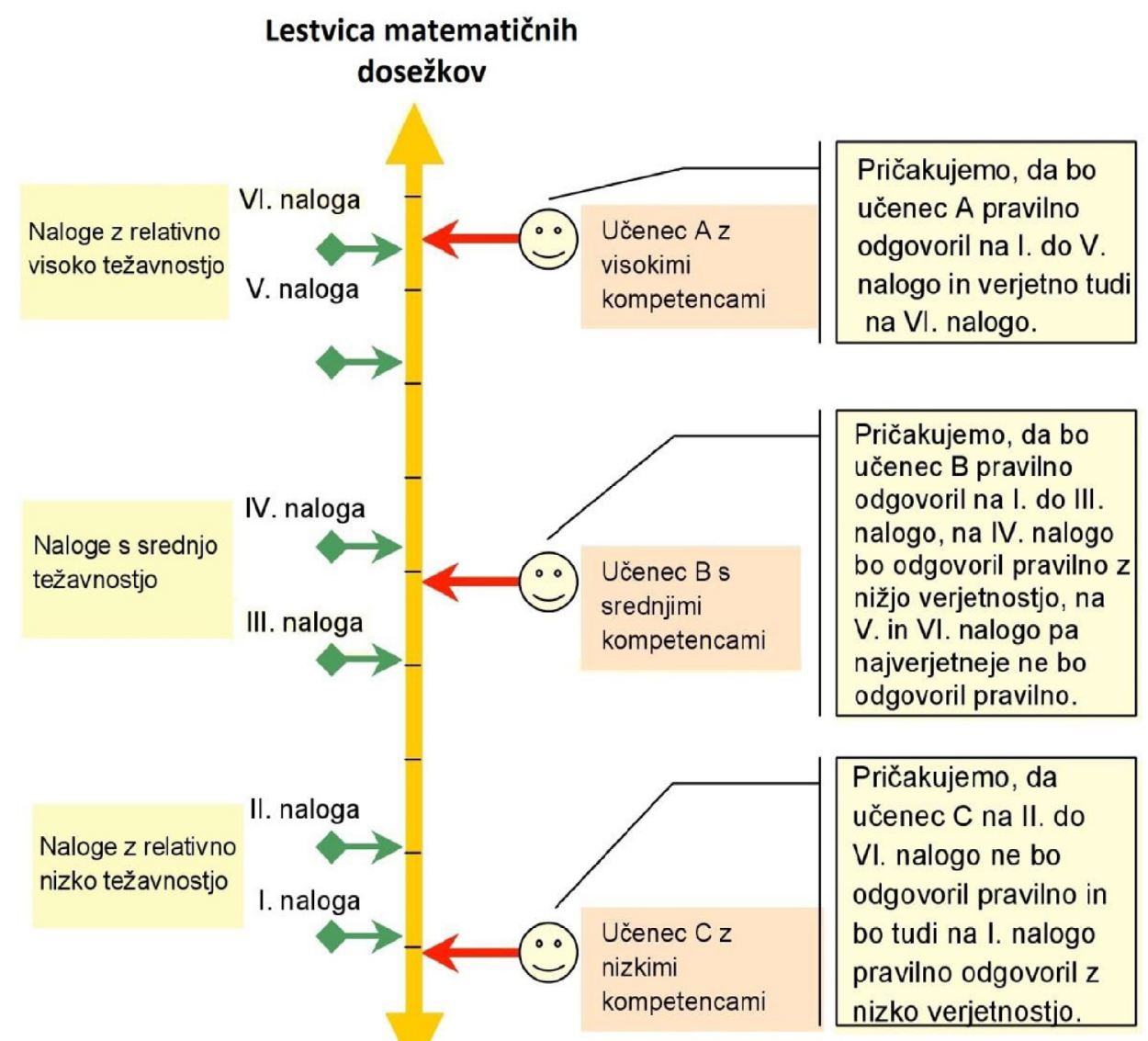

Slika 2: Lestvica matematičnih dosežkov 
Zasnova testa PISA (s tem izrazom tudi v nadaljevanju označujemo različne delovne zvezeke z nalogami, ki so jih reševali dijaki) omogoča konstrukcijo enotne lestvice matematičnih dosežkov, kjer sta upoštevana tako zahtevnost naloge kot dijakove spretnosti in znanje. Vsako vprašanje znotraj testa se uvršča na točno določeno točko na lestvici, ki označuje njegovo zahtevnost, obenem pa je $s$ točno določenim mestom na lestvici povezan tudi uspeh dijaka, ki ga pri tem vprašanju predvidevamo glede na uspešnost dijaka pri ostalih vprašanjih.

Zahtevnost naloge se tako določa na podlagi deleža dijakov, ki so nalogo pravilno rešili, dijakova uspešnost pri določenem vprašanju pa se določi na podlagi deleža vprašanj, ki jih je dijak pravilno odgovoril. Enotna lestvica (glej spodaj; prirejeno po Turner, 2009) tako prikazuje odnos med zahtevnostjo vprašanj in uspešnostjo reševalca le-teh. Ker lestvica zajema zahtevnost vsakega vprašanja, je na podlagi tega možno določiti tudi nivo matematičnega znanja, ki ga vprašanje zahteva, in znanje, ki ga dijak ima.

$\mathrm{Na}$ podlagi uspešnosti dijaka na testu lahko tako predvidevamo, katera vprašanja bi rešil uspešno. Dijak bi najverjetneje pravilno odgovoril na vprašanja, ki se nahajajo na ali pod ravnjo pismenosti, na katero se uvršča na lestvici. Nasprotno pa je manjša verjetnost, da bi pravilno odgovoril na vprašanja, ki se nahajajo nad to ravnjo. Višja kot je raven matematične pismenosti dijaka na lestvici v primerjavi s točko, na kateri se nahaja vprašanje, večja je verjetnost, da bi nanj pravilno odgovoril in obratno.

Tabela 2: Opis ravni matematične pismenosti

\begin{tabular}{|l|l|}
\hline 6 & Dijaki, ki se uvrščajo na 6. raven matematične pismenosti, \\
- znajo konceptualizirati, posploševati in uporabljati podatke na podlagi lastnih raziskovanj in \\
modeliranja zapletenih problemskih situacij. \\
• Povezujejo različnepodatkovne vire in prikaze in jih spretnopretvarjajo iz enega v drugega. Na tem \\
nivoju so dijaki sposobni naprednega matematičnega mišljenja in sklepanja. Ti dijaki lahko upora- \\
bijo lastne uvide in razumevanje, hkrati pa obvladajo simbolne in formalne matematične operacije \\
in odnose, da bi razvili nove pristope in strategije pri reševanju novih situacij. \\
• Dijaki na tej ravni znajo formulirati in natančno posredovati svoja dejanja in refleksije glede svo- \\
jih odkritij, interpretacij, argumentov in oceniti, ali so ustrezni glede na tiste, ki so zastavljeni v pr- \\
votni situaciji. \\
Dijaki, ki se uvrščajo na s. raven matematične pismenosti, \\
- znajo razvijati modele in delati z njimi v kompleksnih situacijah, prepoznavajo omejitve in po- \\
drobneje opredelijo domneve. \\
- Znajo izbirati, primerjati in evalvirati ustrezne strategije reševanja problema, s katerimi se lahko \\
lotijo kompleksnih problemov, ki so povezani s temi modeli. Dijaki na tem nivoju lahko delujejo \\
strateško in pri tem uporabljajo siroko, dobro razvito mišljenje in spretnosti sklepanja, prilagajajopo- \\
vezane prikaze, simbolne in formalne opise in razumejo situacije. \\
• Znajo reflektirati lastna dejanja in formulirati in posredovati svoje interpretacije in sklepanje.
\end{tabular}


Dijaki, ki se uvrščajo na 4. raven matematične pismenosti,

- znajo razrešiti jasno zastavljene modele kompleksnih in konkretnih situacij, ki lahko obsegajo omejitve ali tvorjenje predpostavk.

- Znajo izbrati in povezovati različne prikaze, tudi simbolne in jih neposredno povezujejo z vidiki situacij iz resničnega sveta. Na tem nivoju znajo dijaki uporabljati dobro razvite spretnosti in sklepati, hkrati pa imajo vsaj delno tudi uvid v te kontekste.

- Znajo oblikovati in posredovati razlago in argumente, ki temeljijo na njihovih interpretacijah, argumentih in dejanjih.

Dijaki, ki se uvrščajo na 3. raven matematične pismenosti,

- znajo izpeljati jasno opisane postopke, med njimi tudi tiste, ki zahtevajo zaporedno sprejemanje odločitev. Znajo izbrati in uporabiti strategije preprostega reševanja problemov. Dijaki na tem nivoju znajo interpretirati in uporabljati prikaze, ki temeljijo na različnih podatkovnih virib in sklepajo neposredno na podlagi njih.

- Znajo na kratko posredovati in poročati o svojih interpretacijah, rezultatih in sklepanju.

Dijaki, ki se uvrščajo na 2. raven matematične pismenosti,

- znajo interpretirati in prepoznavati situacije $\mathrm{v}$ kontekstih, ki zahtevajo neposredno sklepanje.

- Znajo izločiti pomembne podatke iz enega vira in uporabljati predstavitvene modele. Dijaki na tem nivoju znajo uporabljati osnovne algoritme, formule, postopke in dogovore.

- Sposobni so neposrednega sklepanja in dobesedne interpretacije rezultatov.

Dijaki, ki se uvrščajo na I. raven matematične pismenosti,

- znajo odgovarjati na vprašanja iz znanih kontekstov, pri katerih so navedeni vsi pomembni podatki in

- izpeljati rutinske postopke glede na neposredna navodila veksplicitno zastavljenih situacijah.

- Znajo izvršiti dejanja, ki so očitna in takoj sledijo danemu uvodnemu besedilu.

Naj na tem mestu 6 ravni matematične pismenosti podrobneje opišemo. Besedilo, ki se na določeni ravni pojavlja v ležečem tisku, je bistveno za razlikovanje od preostalih ravni.

Podobne lestvice je mednarodni center pripravil tudi za štiri prej omenjene vsebinske sklope, ki v tem primeru predstavljajo t. i. podlestvice matematične pismenosti (spremenljivke in odnosi, liki in telesa, količine in verjetnost ter delo s podatki). Poleg tega pa so po opravljenem pilotskem preizkusu razvili tudi dodatne podlestvice zahtevnostnih stopenj, ki temeljijo na treh matematičnih procesih - matematičnemu formuliranju situacij, uporabi matematičnib konceptov, dejstev, postopkov in sklepanj in interpretiranju, uporabi in evalviranju matematičnih rezultatov.

Več o podlestvicah matematične pismenosti lahko preberete v prihajajočem mednarodnem poročilu raziskave PISA 2012 (Vol. I) (OECD, 20I3). 



\section{Opredelitev matematične pismenosti}

Razumevanje matematike je osrednjega pomena v usposobljenosti mladega človeka za življenje v sodobni družbi. Vedno zahtevnejši problemi in situacije, s katerimi se srečuje v vsakdanjem življenju, tudi v poklicnih kontekstih, zahtevajo določeno raven razumevanja matematike, matematično sklepanje in uporabo matematičnih orodij. Matematika je ključno orodje za mlade ljudi pri spopadanju z vprašanji in izzivi na osebnem, poklicnem, družbenem in znanstvenem področju življenja. Zato je pomembno razumeti, v kolikšni meri so mladi ljudje, ki zaključujejo šolanje, ustrezno pripravljeni uporabljati matematiko, ki jim omogoča, da se soočajo s pomembnimi vprašanji in smiselno rešujejo probleme. Ugotavljanje matematične pismenosti pri is letih starosti je zgodnji pokazatelj, kako se bodo posamezniki pozneje v življenju odzivali na različne vrste situacij, ki terjajo matematično obravnavo.

Mednarodno ugotavljanje matematične pismenosti pri is-letnih dijakih temelji na smiselnem vprašanju: »Kaj morajo državljani vedeti in biti sposobni narediti v situacijah, ki vključujejo matematiko? « Natančneje, kaj matematična kompetenca omogoča is-letniku, ki je končal šolanje in se namerava usposobiti za poklic ali pa se pripravlja na študij na univerzi? Matematično pismenost v tem dokumentu opredeljujemo kot niz posameznikovih zmožnosti, da matematično formulirajo, uporabljajo matematiko in interpretirajo matematične izračune v raznolikih kontekstih. Želimo opisati zmožnosti posameznikov, da razmišljajo matematično in uporabljajo matematične koncepte, postopke, dejstva in orodja, s katerimi opisujejo, razlagajo in predvidevajo pojave. Takšna zasnova matematične pismenosti podpira dvoje: razvoj dijakovega poglobljenega razumevanja strogo matematičnih konceptov in prednosti, ki jih prinaša raziskovanje abstraktnega sveta matematike. Struktura matematične pismenosti, ki je opredeljena v raziskavi PISA 20 2, poudarja, 
da je potrebno pri dijakih spodbujati zmožnost uporabe matematike v življenjskem kontekstu, kar lahko dosežemo le tako, da pri pouku matematike pridobijo bogate izkušnje. Poleg tega lahko trdimo, da se pri vseh dijakih poveča motivacija za učenje matematike, ko se zavedo, da je njihovo znanje pomembno izven šole in pri drugih učnih predmetih.

Matematična pismenost je vseživljenjski proces. Toda pri raziskovanju matematične pismenosti I 5 -letnikov moramo upoštevati pomembne značilnosti; to pomeni, da moramo opredeliti vsebino, jezik in kontekste, ki ustrezajo njihovi starosti. V izhodiščih razlikujemo med širšimi vsebinskimi kategorijami, ki so pomembne za matematično pismenost ljudi na splošno, in specifičnimi vsebinskimi poudarki, ki so primerni za I5-letne dijake. $M a-$ tematična pismenost ni lastnost, ki jo posameznik bodisi ima bodisi nima, temveč je ena od lastnosti na kontinuumu, kjer so nekateri posamezniki bolj matematično pismeni kot drugi.

Definicija matematične pismenosti v raziskavi PISA 2012 je naslednja: Matematična pismenost je posameznikova zmožnost formuliranja pojavov $v$ matematičnem jeziku, uporabe in interpretiranja matematičnih rešitev $v$ raznolikih kontekstih. Obsega matematično razmisljanje in uporabo matematicnih konceptov, postopkov, dejstev in orodij, s katerimi opisujemo, razlagamo in predvidevamo pojave. Posamezniku pomaga prepoznati vlogo matematike v svetu in sprejemati dobro utemeljene presoje in odločitve, kakršne potrebujejo ustvarjalni, dejavni in razmišljujoči državljani.

V nadaljevanju sledi razlaga nekaterih pojmov, s katerimi bomo izpostavili in razčlenili tiste vidike opredelitve, ki so še posebej pomembni.

\section{PISA 20I2: dijaki kot aktivni reševalci problemov}

Besedišče v opredelitvi matematične pismenosti poudarja aktivno udeleženost v matematiki in obsega matematično razmišljanje ter uporabo matematičnih konceptov, postopkov, dejstev in orodij pri opisovanju, razlaganju in predvidevanju pojavov. Zlasti glagoli

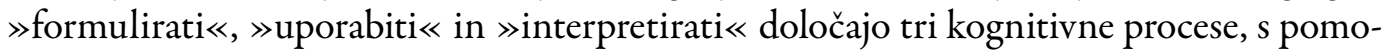
čjo katerih so dijaki udeleženi kot aktivni reševalci problemov. Matematičnoformuliranje pomeni prepoznavanje priložnosti in primernosti uporabe matematike - torej prepoznavanje, ali matematika omogoča razumevanje, obravnavo in rešitev danega problema ali izziva. To pomeni, da smo sposobni sprejeti predstavljeno situacijo in jo pretvoriti v obliko, ki jo lahko obravnavamo z matematičnega vidika, z matematičnimi strukturami in prikazi, pri tem pa prepoznavamo spremenljivke in poenostavljamo domneve, $s$ katerimi si pomagamo pri spoprijemanju z izzivom oziroma pri rešitvi problema. Uporaba matematike obsega uporabo matematičnega sklepanja in matematičnih konceptov, postopkov, dejstev 
in orodij, da bi izpeljali matematično rešitev. To vključuje računanje, uporabo algebraičnih izrazov in enačb ali drugih matematičnih modelov, matematično analiziranje podatkov na podlagi diagramov in grafov, razvijanje matematičnih opisov in razlag ter uporabo matematičnih orodij pri reševanju problemov. Interpretiranje matematičnih rešitev obsega razmišljanje o matematičnih rešitvah ali ugotovitvah, ki jih tolmačimo v kontekstu danega problema ali izziva. To vključuje vrednotenje matematičnih rešitev ali sklepanj na podlagi konteksta, v katerega je umeščen problem, in opredelitev, ali so rezultati v dani situaciji ustrezni in smiselni.

$S$ tem, ko posamezniki uporabljajo matematiko in matematična orodja za reševanje problemov v kontekstu, napredujejo skozi različne stopnje matematične pismenosti. Slika 3 prikazuje pregled poglavitnih struktur izhodišč in njihovo medsebojno povezavo.

IZZIVI V ŽIVLJENJSKEM KONTEKSTU

Matematične vsebine: Količine, Verjetnost in delo s podatki, Spremenljivke in odnosi, Liki in telesa

Matematični kontekst: osebni, družbeni, poklicni, znanstveni

MATEMATIČNO RAZMIŠLJANJE IN DEJANJA

Matematični koncepti, znanja in spretnosti

Temeljne matematične kompetence: sporočanje, predstavljanje, oblikovanje strategij za reševanje problemov, matematiziranje, sklepanje in utemeljevanje, uporabljanje simbolnega, formalnega in tehniškega jezika in operacij, uporaba matematičnih orodij

Procesi: formuliranje, uporaba, interpretiranje/evalviranje

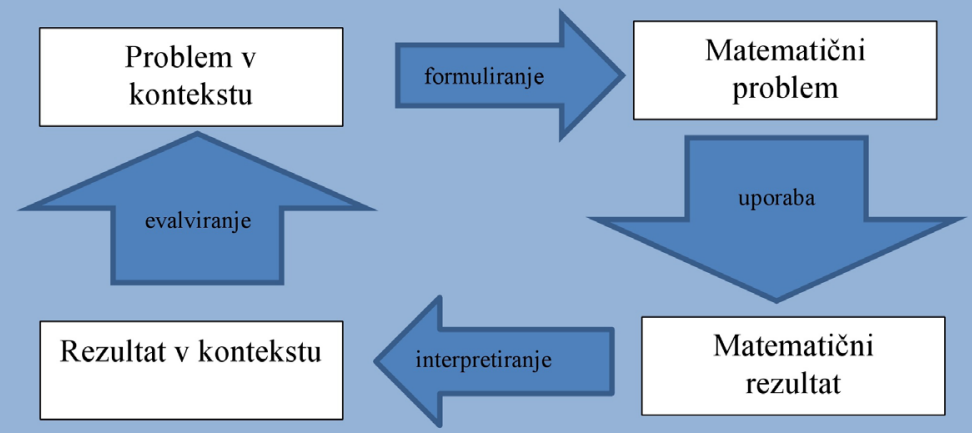

Slika 3: Model matematične pismenosti v praksi 
- Zunanji kvadratek na Sliki 3 kaže, da je matematična pismenost umeščena v kontekst izziva ali problema, ki se pojavi v resničnem svetu. V naših izhodiščih so ti izzivi opredeljeni na dva načina: $\mathrm{z}$ vrsto konteksta in $\mathrm{z}$ matematično vsebino. Kontekstualne kategorije (Vrste kontekstov), ki jih bomo podrobneje opisali pozneje, opredeljujejo tista področja življenja, kjer se problemi zastavljajo. Kontekst je lahko osebni in vključuje probleme ali izzive, s katerimi se srečuje posameznik, njegova družina ali vrstniška skupina. Nadalje je problem lahko umeščen v družbeni kontekst (in osredinjen na posameznikovo skupnost - bodisi krajevno bosisi nacionalno bodisi globalno), poklicni kontekst (osredinjen na svet dela in poklica) ali znanstveni kontekst (povezan $s$ prilagajanjem matematike svetu narave, znanosti in tehnologije). Problemi pa so opredeljeni tudi glede na matematične vsebine. $\mathrm{V}$ okviru raziskave PISA $20 \mathrm{I} 2$ poznamo štiri kategorije matematičnih vsebin (Količina, Verjetnost in delo s podatki, Spremenljivke in odnosi ter Liki in telesa), ki so prav tako prikazane v zunanjem kvadratku 3. slike.

- Posamezniki morajo pri reševanju takšnih, v kontekst umeščenih problemov, matematično razmišljanje in dejanja prilagoditi izzivu, to pa v izhodiščih opredeljujemo na tri načine. Prvič, na 3. sliki upoštevamo dejstvo, da mora posameznik pri delu črpati iz raznolikih matematičnih konceptov, znanj in spretnosti. Matematično znanje izhaja iz posameznikovega prikazovanja in posredovanja matematike, snovanja strategij, sklepanja in podkrepitve trditev $\mathrm{z}$ argumenti. Ta matematična dejanja so v izhodiščih opredeljena glede na sedem osnovnih matematičnih kompetenc, ki so navedene v 3. sliki, in pozneje podrobneje opisane. Medtem ko se posameznik ukvarja s problemom - ki lahko vključuje formuliranje, uporabo matematičnih konceptov in postopkov ter interpretiranje matematičnih rešitev -, se osnovne matematične kompetence uspešno in sočasno aktivirajo, pri tem pa izhajajo iz ustrezne matematične vsebine, $s$ katero ustvarimo rešitev.

Vizualni prikaz cikla matematičnega modeliranja v notranjem kvadratku na 3. sliki prikazuje poenostavljeno različico stopenj, ki jih premaguje dijak, ko dokazuje nivo svoje matematične pismenosti. Prikazuje idealen niz stopenj, ki se začnejo $s \gg$ problemom v kontekstu«. Dijak poskuša opredeliti pomembne matematične pojme v problemski situaciji, ki jo matematično formulira glede na koncepte in prepoznane odnose ter poenostavi svoje domneve. Tako »problem v kontekstu « pretvori v »matematični problem «, ki ga lahko matematično obdela. Puščica, ki je na 3. sliki usmerjena navzdol, prikazuje pot, ki jo med delom ubere dijak, ko uporabi matematične koncepte, postopke, dejstva in orodja, da 
bi prišel do »matematičnih rezultatov《. Ta stopnja običajno vključuje matematično sklepanje, obdelavo podatkov, pretvorbo in računanje. Sledi interpretiranje $\gg$ matematičnih rezultatov« glede na prvotno zastavljen problem (»rezultati v kontekstu «). To pomeni, da dijak interpretira, uporablja in evalvira matematične ugotovitve in njihovo smiselnost $\mathrm{v}$ kontekstu problema, ki temelji na resničnem problemu. Procesi formuliranja pojavov v matematičnem jeziku, uporabe in interpretiranja matematičnih rešitev so ključni sestavni del cikla matematičnega modeliranja, prav tako pa so ključni sestavni del opredelitve matematične pismenosti. Ti trije procesi izhajajo iz osnovnih matematičnih kompetenc, ki so potrebne za izkazovanje dijakovega matematičnega znanja pri kateri koli vsebinski matematični temi.

Opisani cikel je ključen del zasnove raziskave PISA, ki dijaka opredeli kot dejavnega reševalca problema, kljub temu da pogosto ni udeležen v vsaki posamezni stopnji cikla (Blum et al., 2007). Pogosto se namreč zgodi, da pomembne dele cikla matematičnega modeliranja opravijo drugi, končni uporabnik pa izvede samo nekatere korake, ne pa vseh. Denimo, v nekaterih primerih so matematični prikazi, kot so grafi ali enačbe, navedeni, in jih dijak lahko takoj uporabi, da bi odgovoril na nekatera vprašanja ali sklepal. Zato številne naloge v raziskavi PISA vključujejo samo določene stopnje cikla. V resnici je namreč dijak včasih lahko razpet med procesoma, zato se vrača k prejšnjim odločitvam in domnevam. Vsak posamezen proces lahko predstavlja precejšnje izzive, ki zahtevajo večkratno pot po celotnem ciklu.

\section{PISA 20I2: uporaba raznolikih kontekstov pri reševanju problemov}

$\gg$ Raznolikost kontekstov« v opredelitvi matematične pismenosti smo omenili namerno in načrtno, da bi povezali specifične kontekste, ki jih bomo v izhodiščih podrobneje opisali in ponazorili s primeri. Specifični konteksti sami zase niso tako pomembni, toda štiri izbrane kategorije (osebni, poklicni, družbeni in znanstveni kontekst) odražajo široko paleto situacij, v katerih se posamezniki srečujejo z matematičnimi izzivi in priložnostmi. Opredelitev kaže tudi to, da matematična pismenost pomaga posamezniku prepoznavati vlogo, ki jo igra matematika $\mathrm{v}$ svetu, in sprejemati dobro utemeljene presoje in odločitve, kakršne pričakujemo od ustvarjalnih, dejavnih in razmišljujočih državljanov.

\section{PISA 20I2: vidna vloga matematičnih orodij in tehnologije}

Opredelitev matematične pismenosti izrecno vključuje uporabo matematičnih orodij. Ta orodja so stvarna in digitalna oprema, računalniška programska oprema in pripomoč- 
ki za računanje. Matematična orodja na računalniku so v 2 I. stoletju vsakdanja oprema na delovnih mestih in sčasoma postajajo čedalje bolj prevladujoča. Narava problemov, povezanih z delom, in logično sklepanje sta se z novimi priložnostmi še razširila - pri tem pa se krepijo tudi pričakovanja na področju matematične pismenosti.

Uporaba računal je bila dovoljena pri vseh dosedanjih ugotavljanjih matematične pismenosti v raziskavi PISA, kjer je bilo to v skladu s politiko sodelujoče države. V preteklosti so bile matematične naloge kolikor mogoče tehnološko nevtralne (računalo ni olajšalo njihovega reševanja), pri nekaterih nalogah tipa »papir in svinčnik« iz leta 2012 pa so si dijaki z računalom lahko učinkovito pomagali. Naloge v raziskavi PISA 2012 odražajo probleme, ki se pojavljajo v osebnem, poklicnem, družbenem in znanstvenem kontekstu, in ker računala uporabljamo v vseh omenjenih okoljih, so bila na voljo kot pomoč tudi pri nekaterih nalogah. 


\section{Vidiki matematične pismenosti}

$\mathrm{V}$ raziskavi ugotavljamo, v kolikšni meri znajo Is-letniki spretno uporabiti matematiko, ko se srečajo z različnimi situacijami in problemi - večina jih je umeščenih v resnični kontekst.

Matematično pismenost $\mathrm{v}$ raziskavi PISA 2012 določajo naslednji, medsebojno povezani, temeljni vidiki:

- matematične vsebine in njihova uporaba, ki jih preverjamo v nalogah,

- matematični procesi, ki opisujejo, kaj naredijo dijaki, da bi kontekst problema povezali z matematiko in tako rešili problem, in katere kompetence zahtevajo tovrstni procesi, ter

- konteksti, v katere so umeščene naloge.

V nadaljevanju bomo te vidike podrobneje razložili. S poudarkom na teh vidikih smo zagotovili, da naloge, ki so bile zasnovane za potrebe raziskave, odražajo celo vrsto vsebin, procesov in kontekstov, hkrati pa v celoti in učinkovito zajemajo tisto, kar smo opredelili kot matematično pismenost. To poglavje izhodišč temelji na vprašanjih, ki so osnova opredelitve matematične pismenosti:

- Katero znanje matematičnih vsebin lahko pričakujemo pri posameznikih zlasti pri is-letnih dijakih?

- Katere kognitivne procese aktivirajo posamezniki, ko rešujejo matematične probleme, ki so umeščeni v določen kontekst, in katere kompetence naj bi pokazali, ko se njihova matematična pismenost razvija?

- V katerih kontekstih lahko opazujemo in ugotavljamo matematično pismenost? 


\section{Matematične vsebine}

Razumevanje matematičnih vsebin - in zmožnost uporabe tega znanja pri reševanju smiselnih, v kontekst umeščenih problemov - je pomembno za državljane sodobnega sveta. Da bi lahko reševali probleme in interpretirali situacije v osebnih, poklicnih, družbenih in znanstvenih kontekstih, moramo uporabiti določeno matematično znanje in razumevanje.

Matematične strukture se skozi čas razvijajo kot sredstvo, $s$ katerim pojmujemo in interpretiramo naravne in družbene pojave. V šolah je učni kurikulum za matematiko ponavadi opredeljen z vsebinskimi sklopi, kot so npr. aritmetika, algebra in geometrija, ter podrobnejšimi seznami tematskih vsebin, ki temeljijo na zgodovinsko uveljavljenih področjih matematike. Toda izven pouka matematike nekega izziva ali situacije, ki se pojavi, pogosto ne spremlja niz pravil in predpisov, ki bi nakazovali, kako naj problem rešujemo. Značilno je, da takšno reševanje zahteva ustvarjalno misel, ki omogoča vpogled v možnosti, kako bi matematiko uporabili v dani situaciji, ki bi jo matematično formulirali. Situacijo lahko pogosto rešujemo na različne načine z različnimi matematičnimi koncepti, postopki, dejstvi ali orodji.

Cilj raziskave PISA je ugotoviti matematično pismenost, zato organizacijska struktura znanja matematičnih vsebin temelji na matematičnih pojavih, ki poudarjajo širše vrste problemov in ki so spodbudili razvoj specifičnih matematičnih konceptov in postopkov. Denimo, številne pogoste situacije temeljijo na matematičnih pojavih, kot sta slučajnost in spreminjanje, zato te situacije lahko analiziramo z razvitimi matematičnimi strategijami in orodji. Takšna organizacija vsebin ni nova, kar z zgledi predstavljata dve znani publikaciji: On the Shoulders of Giants: New Approaches to Numeracy (Steen, 1990) in Mathematics: The Science of Patterns (Devlin, 1994).

Ker so nacionalni učni kurikulumi za matematiko zasnovani tako, da dijaka opremijo z znanjem in spretnostmi, ki omogočajo obravnavanje matematičnih pojavov, kot jih uporabljamo $\mathrm{v}$ raziskavi, je zbirka vsebin tesno povezana $\mathrm{z}$ vsebinami, ki so del nacionalnega kurikuluma za matematiko.

Da bi področje matematike prilagodili ugotavljanju matematične pismenosti, moramo izbrati strukturo, ki izhaja iz zgodovinskega razvoja matematike in je dovolj raznolika in poglobljena, da razkriva bistvo matematike, hkrati pa na sprejemljiv način predstavlja ali vključuje predpisane matematične standarde. $\mathrm{Z}$ zgodovinskega vidika je matematika $\mathrm{z}$ iznajdbami analitične geometrije in infinitezimalnega računa postala integrirani študij števil, likov, spremenljivk in odnosov; analiza pojavov, kakršna sta slučajnost in nedo- 
ločenost, pa je postala ključna pri reševanju problemov v 19. in 20. stoletju. Tako smo niz vsebinskih kategorij, ki odražajo celo vrsto osnovnih matematičnih pojavov, izbrali za izhodišča raziskave PISA 20I2, saj ustrezajo kategorijam, ki smo jih uporabili že v prejšnjih ciklih raziskave PISA.

Spodnji seznam vsebinskih sklopov smo uporabili v raziskavi PISA 20ı 2, da bi izpolnili zgodovinsko pogojene zahteve razvoja in pokrili področje matematike in osnovnih pojavov, ki spodbujajo njen razvoj in odražajo poglavitne standarde učnih kurikulov. Ti štirje vsebinski sklopi opredeljujejo celo vrsto matematičnih vsebin, ki so osrednjega pomena na področju matematike in ponazarjajo širša vsebinska področja, ki so nas vodila pri razvijanju pilotskih nalog v raziskavi PISA 2012:

- $\quad$ Spremenljivke in odnosi

- Liki in telesa

- Količine

- Verjetnost in delo s podatki

S temi štirimi kategorijami matematičnih vsebin lahko področje matematike uredimo tako, da razpršimo naloge po celotnem področju in se pri tem osredinimo na pomembne matematične pojave. Medtem ko je razvrščanje v vsebinske sklope pomembno pri snovanju in izboru nalog ter pri poročanju o izsledkih raziskave, moramo opozoriti, da se nekatere specifične vsebinske teme lahko uporabijo v več kot enem vsebinskem sklopu. Denimo, naloga, ki smo jo v raziskavi poimenovali Pice (glej Izhodišca merjenja matematićne pismenosti 2006, str. I28), od dijaka zahteva, da opredeli, katera izmed dveh okroglih pic, ki imata različna premera in različni ceni, vendar enako debelino, je cenovno ugodnejša. Tovrstna naloga sega na več področij matematike, med njimi merjenje, količine (glede na vrednost denarja, delno sklepanje in računanje) ter spremenljivke in odnose (v smislu odnosov med spremenljivkami in odvisnosti nastopajočih količin od velikosti pice). To nalogo smo nazadnje uvrstili v kategorijo nalog, ki spadajo v vsebinski sklop Spremenljivke in odnosi, saj se ključ do rešitve problema skriva v tem, da morajo dijaki povezati različno ploščino pic, na voljo pa imajo samo podatek o različnih premerih in pripadajočih cenah. Drugačna naloga bi seveda vključevala površino kroga in bi jo lahko uvrstili med naloge vsebinske kategorije Liki in telesa. Povezave med tistimi vsebinskimi vidiki, ki so razpršeni po vseh štirih vsebinskih sklopih, omogočajo koherenco matematike kot discipline in so očitne v nekaterih nalogah, ki so bile izbrane v raziskavi PISA 2012. 
Učni standardi, ki smo jih pregledali, da bi vsebinske teme izpostavili, kažejo, kaj se poučuje pri pouku matematike v teh državah, hkrati pa so kazalci tega, kar v teh državah pojmujejo kot pomembno znanje in spretnosti, ki bodo dijake te starosti pripravile, da bodo postali ustvarjalni, dejavni in razmišljujoči državljani.

Opisi znanja matematičnih vsebin, ki opredeljujejo vsakega od štirih vsebinskih sklopov - Spremenljivke in odnosi, Liki in telesa, Količine in Verjetnost in delo spodatki - so na voljo spodaj.

\section{Spremenljivke in odnosi}

V naravnih in umetno načrtovanih svetovih zasledimo številne občasne in stalne odnose med objekti. Zasledimo tudi okoliščine, kjer so objekti medsebojno povezani in vplivajo en na drugega. Spremembe se lahko dogajajo skozi čas ali pa zaradi vpliva drugih objektov. Lahko so diskretne ali pa zvezne. Večja pismenost na področju sprememb in odnosov pomeni boljše razumevanje osnovnih vrst odnosov, njihovo prepoznavanje in povezovanje $\mathrm{z}$ ustreznimi modeli, ki spremembe opisujejo in napovedujejo. $Z$ matematičnega vidika to pomeni, da dijak modelira spremembe in odnose $z$ ustreznimi funkcijami in enačbami, jih grafično in simbolno predstavlja, raznovrstne predstavitve ustvarja, interpretira in pretvarja.

Spremenljivke in odnose je mogoče opaziti v tako raznolikih okoljih, kot so organizmi, ki se spreminjajo, ko rastejo, glasba, menjavanje letnih časov, vremenske spremembe, stopnje zaposljivosti in gospodarski pogoji. Vidiki uveljavljenih matematičnih vsebin, kot so funkcije in algebra, ki uporabljajo algebraične izraze, enačbe in neenačbe, tabelarične in grafične prikaze, imajo osrednjo vlogo pri opisovanju, modeliranju in interpretiranju pojava spreminjanja. Naloga, ki v raziskavi PISA 2012 ponazarja vsebinski sklop Spremenljivke in odnosi, na primer od dijaka zahteva, da uporabi dano formulo za dolžino koraka - formula je izražena v algebraični obliki -, medtem ko iz konteksta pravilno razbere število korakov in dolžino poti.

Naslednji primer matematičnih vsebin, ki zajemajo področje spremenljivk in odnosov, je statistika. Predstavitve podatkov in odnosov, kakršne pogosto srečamo pri statistiki, prav tako opisujejo spremembe in odnose, razumevanje tovrstnih odnosov in predstavitev pa zahteva dobro poznavanje števil in enot.

Tudi znotraj področja geometrije opazimo koncept spremenljivk in odnosov. Nekatera zanimiva razmerja izhajajo iz geometričnih merjenj, denimo v tem, kako so spremembe v premeru neke skupine likov povezane s spremembami ploščine, ali pa v razmerju med dolžinami stranic trikotnika. 


\section{Liki in telesa}

Liki in telesa obsegajo širok niz pojavov, ki jih lahko srečamo kjer koli v vidno zaznavnem svetu: vzorce, značilnosti predmetov, položaje in orientacije, upodobitve predmetov, členjenje in razčlenjevanje vizualnih informacij, navigacijo in dinamično interakcijo z resničnimi liki ter prikazi likov. Geometrija je bistvena osnova Likov in teles, čeprav vsebinski sklop presega uveljavljeno geometrijo po vsebini, pomenu in metodi, saj pri tem izhaja iz elementov, ki so del drugih matematičnih področij, denimo prostorski prikazi, merjenje in algebra. Telesa se na primer lahko spremenijo, točka se lahko premika po krivulji, kar zahteva razumevanje pojma funkcije. Formule za merske količine so na tem področju ključnega pomena. V ta vsebinski sklop spada delo s telesi in interpretacija teles v okoljih, v katerih je potrebno uporabiti orodja, ki obsegajo vse od programske opreme za dinamično geometrijo do programske opreme za sistem globalnega določanja lege (GPS).

$\mathrm{V}$ raziskavi PISA domnevamo, da je razumevanje osrednjih konceptov in spretnosti pomembno za matematično pismenost, ki je povezana z Liki in telesi. Matematična pismenost $\mathrm{v}$ vsebinskem sklopu Liki in telesa upošteva celo vrsto dejavnosti, kot so razumevanje perspektive (denimo pri slikah), risanje in branje zemljevidov, preoblikovanje teles ob pomoči tehnologije ali brez nje, interpretiranje pogledov na tridimenzionalne prizore z različnih perspektiv in sestavljanje prikazov teles. Pomemben vidik vsebinskega sklopa Liki in telesa so tudi značilnosti oblik. Naloga, s pomočjo katere bi ugotavljali znanja na tem področju, bi na primer od dijaka zahtevala, da s pomočjo navedenih odgovorov v okviru vprašanja zaprtega tipa izmed štirih različnih zasnov vrtnih gredic določi tisto, ki jo lahko obda z 32 metri lesa. Tovrstna naloga bi zahtevala uporabo geometrijskega znanja in sklepanja. Dijak bi imel na voljo dovolj podatkov, da bi lahko naravnost izračunal natančne mere vseh treh oblik, toda pri eni obliki bi bili navedeni napačni podatki, kar pomeni, da bi moral uporabiti spretnosti geometrijskega sklepanja.

\section{Kolicine}

Pojem Količine je morda najbolj prevladujoč in bistven matematični vidik soočanja z našim svetom in delovanja v njem. Obsega izražanje količinske lastnosti predmetov, razmerij, situacij in teles v svetu in pri tem upošteva različne prikaze izražene količine, hkrati pa omogoča presojanje o interpretacijah in argumentih, ki temeljijo na količini. Izražanje količine v svetu pomeni, da razumemo merjenje, štetje, velikosti, kazalce, relativne velikosti, numerične trende in vzorce. Vidiki sklepanja o količini - kot so razumevanje števil, mnogoterih prikazov števil, tekoče računanje, miselno računanje, vrednotenje in ugotav- 
ljanje smiselnosti rezultatov - so bistvo matematične pismenosti, ki je povezana s sklopom Količine.

Izražanje količine je poglavitna metoda, s katero opisujemo in merimo obširen sklop značilnosti različnih vidikov sveta. Omogoča modeliranje situacij, raziskovanje spremenljivk in odnosov, opisovanje in obravnavanje likov in teles, urejanje in interpretiranje podatkov in merjenje ter ugotavljanje verjetnosti. Tako matematična pismenost $\mathrm{v}$ vsebinskem sklopu Količine zahteva poznavanje števil in številskih operacij v raznolikih kontekstih. Naloga Rock koncert (glej Izhodišca merjenja matematične pismenosti 20o6, str. I I7), uporabljena v raziskavi PISA 2003, je primer vsebinskega sklopa Količine. V tej nalogi mora dijak glede na velikost pravokotnega koncertnega prostora oceniti skupno število ljudi, ki se udeležujejo koncerta. Ta naloga vsebuje tudi nekatere elemente, ki so povezani z vsebinskim sklopom Liki in telesa, vendar je prvotno namenjena ugotavljanju površine, ki bi jo potreboval udeleženec koncerta, in glede na celotno razpoložljivo površino računanju, koliko ljudi se bo koncerta lahko udeležilo. Glede na to, da je to naloga z vprašanji izbirnega tipa, lahko dijaki izračun opravijo po vzvratni poti, tako da na podlagi površine koncertnega prostora in vseh možnih odgovorov izračunajo velikost ustreznega prostora za vsakega posameznega udeleženca ter opredelijo, kateri rezultat je najbolj smiseln. Ker so možni odgovori navedeni v tisočicah (npr. 2000, 5000), ta naloga zahteva tudi dijakove spretnosti presojanja.

\section{Verjetnost in delo spodatki}

$\mathrm{V}$ znanosti, tehnologiji in vsakdanjem življenju se srečujemo z verjetnostjo. Verjetnost je torej pojav, ki sega v samo bistvo matematičnega analiziranja številnih problemskih situacij, zato so tudi nastali verjetnostna teorija števil, statistika in tehnike prikazovanja podatkov in opisov. Vsebinski sklop Verjetnost in delo s podatki obsega prepoznavanje, kje so spremembe $\mathrm{v}$ procesih ob hkratnem upoštevanju izražanja količine, soočanje $\mathrm{z}$ verjetnostjo, naključji in napakami pri merjenju. Prav tako obsega oblikovanje, interpretiranje in vrednotenje zaključkov v tistih situacijah, v katerih verjetnost igra osrednjo vlogo. Predstavitev in interpretacija podatkov sta ključna koncepta tega vsebinskega sklopa (Moore, 1997).

Verjetnost je del znanstvenih predvidevanj, rezultatov anket, vremenskih napovedi in ekonomskih modelov. Ustaljena področja učnih kurikulov verjetnosti in statistike nudijo formalna sredstva za opisovanje, modeliranje in interpretiranje določenih vrst verjetnostnih pojavov in sklepanj. Poleg tega poznavanje števil in vidikov algebre, kot so grafi in simbolni prikazi, prispeva $\mathrm{k}$ lažjemu obravnavanju problemov tega vsebinskega sklopa. 
Tudi interpretacija in predstavitev podatkov sta pomemben vidik vsebinskega sklopa Verjetnosti in dela spodatki. Naloga, ki bi obravnavala področje Verjetnost in delo spodatki, bi od dijaka na primer zahtevala, da mora oceniti podatke, dane v tabeli, in pojasniti, zakaj palični diagram ni primeren za prikaz določenih podatkov.

\section{Vsebine matematične pismenosti bolj podrobno}

Štirje vsebinski sklopi, Spremenljivke in odnosi, Liki in telesa, Količine in Verjetnost in delo s podatki, so osnova, s katero smo opredelili razpon vsebin, vendar te niso strogo omejene. Denimo, sklepanje se lahko izrazi prek zelo različnih kontekstov, kot so pretvarjanje merskih količin, analiziranje linearnih odnosov, računanje verjetnosti in ocenjevanje dolžine stranic pri podobnih likih. Da bi učinkovito razumeli in reševali probleme, umeščene $\mathrm{v}$ omenjene vsebinske sklope, moramo izhajati iz različnih matematičnih konceptov, postopkov, dejstev in orodij ter jih uporabiti na ustrezno poglobljeni zahtevnostni ravni.

Da bi na mednarodni ravni pripravili gradivo, ki bi odražalo znanje matematike, ki naj bi ga Is-letniki imeli priložnost usvojiti, je bila opravljena študija matematičnih standardov znanja v enajstih državah, z namenom opredeliti dvoje: kaj se dijaki učijo pri pouku matematike po svetu in kaj države ocenjujejo kot pomembno za njihovo pripravo ob vstopu v svet dela ali sprejemu na visokošolsko izobraževalno ustanovo. Glede na skupne značilnosti, ki so bile prepoznane $v$ teh analizah, skupaj s presojo strokovnjakov s področja matematike, so bile v okviru prej omenjenih štirih vsebinskih področij v raziskavi PISA 2012 vključene naslednje, podrobnejše vsebine:

- Funkcije: Koncept funkcij, ki poudarja linearne funkcije, vendar ni omejen samo nanje in njihove značilnosti. Njihove predstavitve so pogosto verbalne, simbolne, tabelarične in grafične.

- Algebraični izrazi: Verbalne interpretacije in uporaba algebraičnih izrazov, ki vključuje števila, simbole, računske operacije in preproste korene.

- Enačbe in neenaćbe: Linearne in druge enačbe ter neenačbe, preproste enačbe druge stopnje in analitične ali neanalitične metode reševanja.

- Koordinatni sistemi: Prikazi in opisi podatkov, položajev in odnosov.

- Razmerja znotraj geometrijskih teles in razmerja med njimi $v$ dveh ali treh dimenzijah: Statična razmerja, kot so algebraične povezave med elementi številk (npr. Pitagorov izrek, ki opisuje odnos med dolžinami stranic pravokotnega trikotnika, relativni položaj, podobnost in skladnost) ter dinamična razmerja, ki vključujejo preoblikovanje in gibanje teles, prav tako pa skladnost med dvo- ali trodimenzionalnimi telesi. 
- Merjenje: Izražanje količinske lastnosti teles in predmetov in količinska razmerja med njimi, kot so merjenja kotov, razdalje, dolžine, robovi, obseg, površina in prostornina.

- Števila in enote: Koncepti, prikazi števil in številskih sistemov, med njimi lastnosti celih in racionalnih števil, pomembni vidiki iracionalnih števil, prav tako pa količine in enote, povezane s pojavi, kot so čas, denar, teža, temperatura, razdalja, površina in prostornina, in iz njih izpeljane količine z numeričnimi opisi.

- Aritmetične operacije: Narava in lastnosti teh operacij in z njimi povezanih zapisov.

- Odstotki, razmerja in deleži: Numerični opisi relativne velikosti in uporaba sorazmerij in sorazmernega sklepanja pri reševanju problemov.

- Načela preštevanja: preproste kombinacije in permutacije.

- Ocenjevanje: Približna ocena količin in vrednosti numeričnih izrazov, značilne števke in zaokrožanje.

- Zbiranje podatkov, prikaz in interpretacija: značilnosti, izvor in zbiranje različnih vrst podatkov in različni načini njihovega prikazovanja in interpretiranja.

- Spremenljivost in opisovanje podatkov: Pojmi, kot so spremenljivost, porazdelitev in mere sredine podatkovnih nizov ter načini opisovanja in interpretiranja $z$ izrazi, ki opisujejo količino.

- Vzorci in vzorčenje: Koncepti vzorčenja in vzorčenje podatkov iz populacije ter sklepanje, ki temelji na lastnostih vzorcev.

- Slučajnost in verjetnost: Pojem slučajnih dogodkov, predstavitev variacije, slučajnost in frekvenca dogodkov, osnovni vidiki pojma verjetnosti.

\section{Matematični procesi}

Matematični procesi (najpogosteje imamo v mislih kognitivne procese), ki jih zajema definicija matematične pismenosti v raziskavi PISA 20I2, se nanašajo na posameznikovo zmožnost formuliranja pojavov $v$ matematičnem jeziku, uporabe in interpretiranja matematičnih rešitev. S temi besedami lahko na kratko opišemo, kaj počnejo posamezniki, ko kontekst problema povežejo z matematiko in nato rešijo problem. Raziskava PISA 2012 je na področju znanja matematike prvič poročala o rezultatih glede na uspešnost pri omenjenih matematičnih procesih. Kategorije matematičnih procesov so bile naslednje:

- Matematično formuliranje situacij

- Uporaba matematičnih konceptov, dejstev, postopkov in sklepanja 
- Interpretiranje, uporaba in evalviranje matematičnih rezultatov_

Za snovalce politik in tiste, ki so bolj vpleteni v vsakdanje izobraževanje dijakov, je pomembno vedeti, kako učinkovito se dijaki lahko vključujejo v te procese. Izsledki raziskave PISA na področju formuliranja matematičnih situacij kažejo, kako učinkoviti so dijaki pri prepoznavanju in opredeljevanju priložnosti, $\mathrm{v}$ katerih lahko uporabijo matematiko $\mathrm{v}$ problemskih situacijah in nato poiščejo ustrezno matematično strukturo, $s$ katero problem v kontekstu formulirajo.

Rezultati na področju uporabljanja kažejo, kako dobro so dijaki sposobni računati in obdelovati podatke ter pri tem uporabiti znane koncepte in dejstva, da bi prišli do matematične rešitve matematično formuliranega problema, rezultati na področju procesa interpretiranja pa nam povedo, kako učinkovito znajo dijaki razmišljati o matematičnih rešitvah in zaključkih, jih interpretirati v kontekstu problema iz resničnega sveta in določiti, ali so rezultati in zaključki sprejemljivi.

Zmožnost dijakov, da matematiko prilagodijo problemom in situacijam, je odvisna od njihovih spretnosti $v$ vseh treh omenjenih procesih, razumevanje njihove učinkovitosti $\mathrm{v}$ vsaki posamezni kategoriji pa lahko pomaga pri razpravah na ravni politike in odločitvah, ki so povezane z izvajanjem pouka.

\section{Matematicno formuliranje situacij}

Kot že omenjeno, se izraz formulirati v okviru opredelitve matematične pismenosti nanaša na zmožnost posameznikov, da prepoznajo in opredelijo možnosti uporabe matematike in nato predvidijo matematične strukture za reševanje problema, ki je umeščen v kontekst. V procesu matematičnega formuliranja situacij posamezniki določijo, kje lahko uporabijo matematiko, da bi umestili, analizirali, in rešili problem. Problem iz resničnega sveta prenesejo na področje matematike in ga ponazorijo z matematično strukturo, prikazom in vsemi posebnostmi, ki ga spremljajo. O problemu razmišljajo, osmišljajo omejitve in tvorijo domneve. Natančneje pa proces matematičnega formuliranja situacij vključuje naslednje dejavnosti:

- opredeljevanje matematičnih vidikov problema, ki je umeščen v kontekst resničnega sveta in prepoznavanje pomembnih spremenljivk,

- prepoznavanje matematične strukture v problemih ali situacijah,

- poenostavljanje situacije ali problema z namenom prilagoditve matematični analizi, 
- opredeljevanje omejitev in predpostavk, na katerih sloni matematični model, ki se lahko razbere iz konteksta,

- matematični prikaz situacije z uporabo ustreznih spremenljivk, simbolov, diagramov in standardnih modelov,

- predstavljanje problema na drugačen način, tako da se ga lahko obravnava v skladu z matematičnim konceptom, pri čemer se formulira ustrezne predpostavke,

- razumevanje in pojasnjevanje odnosov med besediščem, ki je omejeno in značilno za določen kontekst problema, in simbolnim ter formalnim izrazjem, ki ga potrebujemo, da besedišče lahko matematično predstavimo,

- pretvorba problema v matematični jezik ali prikaz, torej v standardni matematični model,

- prepoznavanje vidikov problema, ki ustreza znanim problemom ali matematičnim konceptom, dejstvom ali postopkom,

- uporaba tehnologije (kot so preglednice ali seznam zmožnosti na grafičnem računalu) pri prikazovanju matematičnih odnosov, ki nastopajo v problemu, umeščenem v kontekst.

Zgoraj omenjena naloga Pice zahteva predvsem matematično formuliranje situacije. Čeprav od dijakov pričakujemo tudi to, da bodo izvajali računske operacije pri reševanju problema in si smiselno razložili rezultate izračunov pri ugotavljanju, katera pica je cenovno ugodnejša, je resnični kognitivni izziv te naloge v tem, da morajo dijaki formulirati matematični model, ki povzema koncept vrednosti denarja. Dijak, ki rešuje problem, mora uvideti, da imata pici sicer enako debelino, vendar različna premera, zato je analiza usmerjena na področje ploščine kroga. Razmerje med količino pice in vsoto denarja je potrebno združiti v koncept vrednosti denarja, ki je modeliran kot cena na enoto površine.

Prav tako že omenjena naloga Rock koncert je drug primer naloge, ki od dijakov zahteva, da matematično formulirajo situacijo, saj naj bi si pojasnili podatke, ki so umeščeni $\mathrm{v}$ kontekst (npr. velikost in oblika koncertnega prostora, dejstvo, da je rock koncert polno obiskan, in dejstvo, da oboževalci stojijo) in te podatke prevedejo v uporabno matematično obliko, da bi lahko ocenili število obiskovalcev koncerta.

\section{Uporaba matematicnih konceptov, dejstev, postopkov in sklepanj}

Izraz uporaba $\mathrm{v}$ opredelitvi matematične pismenosti se nanaša na posameznikove zmožnosti uporabe matematičnih konceptov, dejstev, postopkov in sklepanja pri reševanju matematično formuliranih problemov, da bi oblikovali matematične zaključke. $\mathrm{V}$ procesu 
uporabe matematičnih konceptov, dejstev, postopkov in sklepanja pri reševanju problemov morajo posamezniki izvesti matematične postopke, ki so potrebni za izpeljavo rezultatov, in poiskati matematično rešitev (npr. z računanjem, reševanjem enačb, logičnimi izpeljavami na podlagi matematičnih domnev, računanjem s simboli, povzemanjem matematičnih podatkov iz tabel in grafov, prikazom in preoblikovanjem teles $\mathrm{v}$ prostoru in analiziranjem podatkov). Ukvarjajo se z modelom problemske situacije, vzpostavljajo pravilnosti, prepoznavajo povezave med matematičnimi entitetami in oblikujejo matematične argumente. Natančneje pa proces uporabe matematičnih konceptov, dejstev, postopkov in sklepanja obsega dejavnosti, kot so:

- $\quad$ izpeljevanje in izvajanje strategij, s katerimi iščemo matematične rešitve,

- uporaba matematičnih orodij,

- uporaba matematičnih dejstev, pravil, algoritmov in struktur pri iskanju rešitev,

- uporaba števil, grafičnih in statističnih podatkov, algebraičnih izrazov in enačb ter geometrijskih prikazov,

- oblikovanje matematičnih diagramov, grafov in struktur ter izpeljevanje matematičnih podatkov iz njih,

- uporaba različnih prikazov v procesu iskanja rešitev in prehajanje med njimi,

- posploševanje na podlagi rezultatov, ki so dobljeni z uporabo matematičnih postopkov pri iskanju rešitev,

- $\quad$ razmišljanje o matematičnih argumentih in razlaganje ter utemeljevanje matematičnih rezultatov.

\section{Interpretiranje, uporaba in evalviranje matematicnih rezultatov}

Izraz interpretirati $\mathrm{v}$ opredelitvi matematične pismenosti je osredinjen na zmožnost posameznika, da razmišlja o matematičnih rešitvah, rezultatih ali zaključkih in jih interpretira v kontekstu problemov iz resničnega sveta. Izraz obsega pretvorbo matematičnih rešitev v kontekst problema ali povratno sklepanje in ugotavljanje, ali so rezultati sprejemljivi in smiselni v kontekstu problema. Ta kategorija matematičnih procesov obsega na sliki 3 obe puščici: tako puščico »interpretiranje « kot puščico »evalviranje«, ki sta prikazani v prej opredeljenem modelu matematične pismenosti v praksi (glej sliko 3). V tem procesu od posameznikov zahtevamo, da oblikujejo in posredujejo razlage in argumente v kontekstu problema, pri tem pa razmislijo o procesu modeliranja in njegovih rezultatih. 
Natančneje pa ta proces interpretiranja, uporabljanja in evalviranja matematičnih rezultatov vključuje dejavnosti, kot so:

- interpretiranje matematičnega rezultata nazaj v kontekst resničnega sveta,

- evalviranje sprejemljivosti matematične rešitve $\mathrm{v}$ kontekstu problema iz resničnega sveta,

- razumevanje, kako v resničnem svetu pride do izida in kako potekajo izračuni $\mathrm{v}$ uporabljenem postopku ali modelu, da bi lahko presojali o tem, kako lahko rezultate prilagodimo ali uporabimo,

- razlaga, zakaj matematični rezultat ali zaključek je oziroma ni sprejemljiv v kontekstu problema,

- razumevanje obsega in omejitev matematičnih konceptov in matematičnih rešitev,

- $\quad$ ocenjevanje in prepoznavanje omejitev modela, ki je bil uporabljen za reševanje problema.

\section{Osnovne matematične kompetence, na katerih temeljijo matematični procesi}

Desetletje izkušenj pri razvijanju nalog za potrebe raziskave PISA in analiziranje načinov, kako se dijaki odzivajo na naloge, je pokazalo, da obstajajo osnovne matematične kompetence, ki so temelj vsakega od omenjenih procesov - na tem pa temelji tudi matematična pismenost $\mathrm{v}$ praksi. Mogens Niss je skupaj z danskimi sodelavci (Niss, 2003, in Niss in Jensen, 2002) opredelil osem kompetenc, ki jih natančneje opisuje že v izhodiščih raziskave PISA 2003 in so koristne pri matematičnem razmišljanju. V izhodiščih raziskave PISA 2012 so strokovnjaki uporabili spremenjeno formulacijo tega niza kompetenc, ki so jih strnili v sedem, in temeljijo na raziskavi, opravljeni s strani MEG (PISA Mathematics expert group), o učinkih prejšnjih nalog na kompetence (Turner, 20I I). Opredelitev takšnega niza splošnih matematičnih kompetenc je nujen, da bi pri učenju matematike dopolnili vlogo specifičnega znanja matematičnih vsebin. Pomembno osnovo (podlago) za opredelitev predstavlja osem matematičnih praks Osrednjih nacionalnih učnih standardov (Common Core State Standards) iz ZDA, štirje ključni procesi (predstavljanje, analiziranje, interpretiranje in evalviranje ter sporočanje) nacionalnega učnega kurikuluma za matematiko v Veliki Britaniji in procesni standardi, ki so jih opredelili v nacionalnem svetu učiteljev matematike (NCTM, 2000) in nosijo naslov Načela in standardi za matematiko v šoli (Principles and Standards for School Mathematics). Opredeljene kompetence po- 
sameznik lahko usvoji, da bi razumel in se dejavno vključeval v svet na matematičen način ali da bi reševal probleme. $S$ tem, ko posameznik razvija matematično pismenost, je sposoben uporabljati čedalje višjo stopnjo osnovnih matematičnih zmožnosti (Watson in Callingham, 2003). Tako se poveča aktivacija osnovnih matematičnih sposobnosti, ki je povezana tudi s zahtevnostno stopnjo nalog. To védenje strokovnjaki na mednarodni ravni raziskave uporabljajo kot osnovo pri opisovanju različnih zahtevnostnih stopenj matematične pismenosti, o katerih bomo govorili v nadaljevanju izhodišč.

7 osnovnih matematičnih kompetenc, ki jih v okviru kategorije procesov uporabljamo $\mathrm{v}$ izhodiščih matematične pismenosti v raziskavi PISA 20I2, so:

- Sporočanje: Posameznik opazi nekatere izzive in je spodbujen pri prepoznavanju in razumevanju problemske situacije. Branje, razčlenjevanje in interpretiranje trditev, vprašanj, nalog ali predmetov daje posamezniku zmožnost, da oblikuje miselni model situacije, kar pa je pomemben korak pri razumevanju, razjasnjevanju in formuliranju problema. Med procesom reševanja mora vmesne rezultate povzeti ali predstaviti. Pozneje, ko je rešitev že odkril, pa jo mora dijak predstaviti in morda razložiti in zagovarjati pred drugimi.

- Matematiziranje: Matematična pismenost lahko obsega pretvorbo problema, ki smo ga opredelili v resničnem svetu, v strogo matematično obliko (ki lahko obsega strukturiranje, konceptualiziranje, domnevanje in/ali formuliranje modela), ali pa interpretiranje in evalviranje matematičnega rezultata ali matematičnega modela glede na prvotno zastavljen problem. Izraz matematiziranje uporabljamo, da bi opisali osnovne matematične dejavnosti.

- Predstavljanje: K matematični pismenosti pogosto vključujemo tudi prikaze matematičnih teles in situacij, kar lahko vključuje izbiranje prikazov, njihovo interpretacijo, pretvarjanje in uporabo različnih prikazov, da bi ujeli situacijo, se ukvarjali s problemom ali predstavili svoje delo. Omenjeni prikazi vključujejo grafe, tabele, diagrame, slike, enačbe, formule, besedilne opise in oprijemljivo gradivo.

- Sklepanje in utemeljevanje: Sklepanje in utemeljevanje imenujemo matematično kompetenco, ki je na preizkušnji v različnih stopnjah in dejavnostih, povezanih z matematično pismenostjo. Ta kompetenca obsega smiselne procese, s katerimi raziskujemo in povezujemo korake pri reševanju problema, zato da lahko sklepamo in preverjamo tisto, kar govori v njihov prid, ali utemeljimo trditve in rešitve problemov. 
- Oblikovanje strategij za rě̌evanje problemov: Matematična pismenost pogosto zahteva oblikovanje strategij za matematično reševanje problemov. Ta kompetenca obsega nabor natančnih procesov nadzorovanja, ki vodijo posameznika pri učinkovitem prepoznavanju, formuliranju in reševanju problemov. Za to spretnost je značilno, da z njo dijak izbere ali oblikuje načrt ali strategijo in matematiko uporabi za reševanje problemov, ki izhajajo iz naloge ali konteksta, hkrati pa usmerja tudi samo izvajanje. To matematično kompetenco lahko uporabimo na kateri koli stopnji v procesu reševanja problema.

- Uporaba simbolnega, formalnega in tehniškega jezika in operacij: Matematična pismenost zahteva uporabo simbolnega, formalnega in tehniškega jezika in operacij. Ta kompetenca obsega razumevanje, interpretiranje in uporabo simbolnih izrazov $\mathrm{v}$ matematičnem kontekstu (med njimi tudi računskih izrazov in operacij), ki jih usmerjajo matematične konvencije in pravila. Obsega tudi razumevanje in uporabo formalnih struktur, ki temeljijo na definicijah, pravilih in formalnih sistemih, ter na uporabi algoritmov v povezavi z omenjenimi entitetami. Uporabljeni simboli, pravila in sistemi se spreminjajo glede na to, kateri del znanja matematičnih vsebin potrebujemo pri določeni nalogi, da lahko formuliramo, rešujemo ali interpretiramo matematiko.

- Uporaba matematičnih orodij: Zadnja matematična kompetenca, na kateri temelji matematična pismenost $\mathrm{v}$ praksi, je uporaba matematičnih orodij. Matematična orodja obsegajo stvarna orodja, kot so meritveni inštrumenti, prav tako pa računala in računalniška orodja, ki postajajo čedalje bolj dostopna. Ta zmožnost obsega poznavanje in védenje o tem, kako uporabljati različna orodja, ki so nam $\mathrm{v}$ pomoč pri reševanju matematičnih nalog, in kako opredeliti njihove omejitve. Matematična orodja igrajo pomembno vlogo tudi pri sporočanju.

Omenjene zmožnosti in sposobnosti so očitne v vsakem od treh matematičnih procesov, ki smo jih uporabili pri poročanju o raziskavi. Kako se le-te kažejo znotraj treh procesov, je opisano v Sliki 4. 


\begin{tabular}{|c|c|c|c|}
\hline & $\begin{array}{l}\text { Matematično FORMULI- } \\
\text { RANJE situacij }\end{array}$ & $\begin{array}{l}\text { UPORABA matematičnih } \\
\text { konceptov, dejstev, postop- } \\
\text { kov in sklepanj }\end{array}$ & $\begin{array}{l}\text { INTERPRETIRANJE, } \\
\text { uporaba in evalviranje mate- } \\
\text { matičnih rezultatov }\end{array}$ \\
\hline $\begin{array}{l}\text { POSREDOVANJE PO- } \\
\text { DATKOV IN REZULTA- } \\
\text { TOV }\end{array}$ & $\begin{array}{l}\text { Bere, razčlenjuje in osmišlja } \\
\text { trditve, vprašanja, opravila, } \\
\text { predmete, podobe ali anima- } \\
\text { cije (pri tipu nalog računal- } \\
\text { nik), da si izoblikuje miselni } \\
\text { model situacije. }\end{array}$ & $\begin{array}{l}\text { Izoblikuje rešitev, pokaže } \\
\text { potek, ki je pripeljal do reši- } \\
\text { tve in/ali povzema in pred- } \\
\text { stavi vmesne matematične } \\
\text { rezultate. }\end{array}$ & $\begin{array}{l}\text { Oblikuje in posreduje razla- } \\
\text { ge in argumente v kontekstu } \\
\text { problema. }\end{array}$ \\
\hline MATEMATIZIRANJE & $\begin{array}{l}\text { Opredeli matematične spre- } \\
\text { menljivke in strukturo pro- } \\
\text { blema iz resničnega sveta in } \\
\text { oblikuje predpostavke. }\end{array}$ & $\begin{array}{l}\text { Matematično konceptuali- } \\
\text { zira (zapiše oz. oblikuje) pro- } \\
\text { blem ali interpretira rešitev } \\
\text { v okviru konteksta, v katere- } \\
\text { ga je problem umeščen (to } \\
\text { je morda potrebno pri tistih } \\
\text { problemih, pri katerih je po- } \\
\text { udarjena uporaba). }\end{array}$ & $\begin{array}{l}\text { Razume obseg in omejitve } \\
\text { matematične rešitve, ki so } \\
\text { posledica uporabljenega ma- } \\
\text { tematičnega modela. }\end{array}$ \\
\hline PRIKAZOVANJE & $\begin{array}{l}\text { Prikaže podatke iz resnič- } \\
\text { nega sveta na matematičen } \\
\text { način. }\end{array}$ & $\begin{array}{l}\text { Osmišlja, povezuje in upora- } \\
\text { blja raznolike prikaze, ko re- } \\
\text { šuje problem. }\end{array}$ & $\begin{array}{l}\text { Interpretira matematične re- } \\
\text { zultate v različnih oblikah } \\
\text { glede na situacijo ali upora- } \\
\text { bo; primerja ali (ocenjuje) } \\
\text { evalvira dva ali več prikazov, } \\
\text { ki so povezani s situacijo. }\end{array}$ \\
\hline $\begin{array}{l}\text { SKLEPANJE IN ARGU- } \\
\text { MENTIRANJE }\end{array}$ & $\begin{array}{l}\text { Pojasni, zagovarja ali upravi- } \\
\text { či opredeljen ali oblikovan } \\
\text { prikaz situacije iz resnične- } \\
\text { ga sveta. }\end{array}$ & $\begin{array}{l}\text { Pojasni, zagovarja ali upravi- } \\
\text { či procese in postopke, ki jih } \\
\text { je uporabil, da bi opredelil } \\
\text { matematični rezultat ali re- } \\
\text { šitev. Povezuje informacije, } \\
\text { oblikuje posplošitve ali argu- } \\
\text { mente, ki so sestavljeni iz več } \\
\text { korakov. }\end{array}$ & $\begin{array}{l}\text { Razmišlja o matematičnih } \\
\text { rešitvah in oblikuje razlage in } \\
\text { argumente, ki podpirajo, iz- } \\
\text { podbijajo ali (označujejo?) } \\
\text { matematične rešitve proble- } \\
\text { mov v kontekstu. }\end{array}$ \\
\hline $\begin{array}{l}\text { OBLIKOVANJE STRA- } \\
\text { TEGIJZA REŠEVANJE } \\
\text { PROBLEMOV }\end{array}$ & $\begin{array}{l}\text { Izbere ali oblikuje načrt ali } \\
\text { strategijo za matematič- } \\
\text { no preoblikovanje proble- } \\
\text { ma, umeščenega v določen } \\
\text { kontekst. }\end{array}$ & $\begin{array}{l}\text { Aktivira učinkovite in vzdr- } \\
\text { žne mehanizme nadzora sko- } \\
\text { zi vse stopnje postopka, ki ga } \\
\text { sestavlja več korakov, kar ga } \\
\text { pripelje do matematične reši- } \\
\text { tve, zaključka ali posplošitve. }\end{array}$ & $\begin{array}{l}\text { Oblikuje in izvaja strategijo, } \\
\text { s katero interpretira, evalvira } \\
\text { in potrjuje matematično reši- } \\
\text { tev problema, ki je umeščen } \\
\text { v kontekst. }\end{array}$ \\
\hline
\end{tabular}




\begin{tabular}{|l|l|l|l|}
\hline $\begin{array}{l}\text { UPORABA SIMBOLNE- } \\
\text { GA, FORMALNEGA IN } \\
\text { TEHNIŠKEGA JEZIKA } \\
\text { IN OPERACIJ }\end{array}$ & $\begin{array}{l}\text { Uporablja ustrezne spre- } \\
\text { menljivke, simbole, diagra- } \\
\text { me in standardne modele, da } \\
\text { bi predstavil problem iz re- } \\
\text { sničnega sveta ob pomoči } \\
\text { simbolnega/formalnega be- } \\
\text { sedišča. }\end{array}$ & $\begin{array}{l}\text { Razume in uporablja formal- } \\
\text { ne strukture, ki temeljijo na } \\
\text { definicijah, pravilih in for- } \\
\text { malnih sistemih, prav tako } \\
\text { pa uporablja algoritme. }\end{array}$ & $\begin{array}{l}\text { Razume razmerje med kon- } \\
\text { tekstom problema in prika- } \\
\text { zom matematične rešitve. } \\
\text { Razumevanje uporabi, da si } \\
\text { pomaga interpretirati rešitev } \\
\text { v kontekstu in preizkuša iz- } \\
\text { peljavo in morebitne omeji- } \\
\text { tve rešitve. }\end{array}$ \\
\hline $\begin{array}{l}\text { UPORABA MATEMA- } \\
\text { TIČNIH ORODIJ }\end{array}$ & $\begin{array}{l}\text { Uporablja matematična } \\
\text { orodja, s katerimi prepozna- } \\
\text { va matematične strukture } \\
\text { ali prikaže matematična raz- } \\
\text { merja in odnose. }\end{array}$ & $\begin{array}{l}\text { Pozna in ustrezno upora- } \\
\text { blja različna orodja, s kate- } \\
\text { rimi si pomaga pri izvajanju } \\
\text { procesov in postopkov pri } \\
\text { opredeljevanju matematič- } \\
\text { nih rešitev. }\end{array}$ & $\begin{array}{l}\text { Uporablja matematična } \\
\text { orodja, skaterimi preverja } \\
\text { sprejemljivost matematične } \\
\text { rešitve in njene omejitve gle- } \\
\text { de na kontekst problema. }\end{array}$ \\
\hline
\end{tabular}

Slika 4: Sedem osnovnih matematičnih kompetenc v okviru treh kategorij procesov

\section{Osnovne matematicne kompetence in njihovo razmerje do zahtevnosti nalog}

Kompetence, ki so znotraj navedenih procesov potrebne za uspešno rešitev določenega matematičnega problema, smo v grobem že opredelili v okviru poglavja Dijaki kot aktivni reševalci problemov, tukaj pa jih opisujemo bolj podrobno. Najtežje naloge zahtevajo kompleksno aktivacijo različnih kompetenc. Predvidevanje zahtevnosti določene naloge zahteva upoštevanje obojega: sposobnosti in zmožnosti ter zahtevano kompleksnost aktivacije. V nadaljevanju opisujemo same kompetence ter značilnosti, zaradi katerih je aktivacija določene kompetence pri reševanju določenega problema bolj ali manj kompleksna.

\section{Sporočanje}

Nivo in obseg posredovanja v nalogi določajo različni dejavniki, zmožnost posameznika, da te zahteve izpolni, pa kaže obseg te kompetence. Glede zaznavnih vidikov sporočanja ti dejavniki vključujejo dolžino in kompleksnost besedila ali druge enote, ki jo je treba prebrati in interpretirati, seznanjenost $\mathrm{z}$ idejami ali podatki, ki so omenjeni v besedilu, obseg, po katerem mora biti podatek izluščen iz množice drugih podatkov, vrstni red podatkov in vprašanje, ali se ujema $\mathrm{z}$ vrstnim redom miselnih procesov, ki so nujni za interpretiranje in uporabo podatkov ter obseg, v katerem so različni elementi (kot so besedilo, grafični elementi, grafi, tabele, diagrami), ki jih je treba interpretirati v razmerju drug do drugega. Najnižji nivo izraznih vidikov sporočanja je zastopan v nalogah, ki zahtevajo samo vnos numeričnega odgovora. V primeru, kadar je zahtevana širša rešitev, denimo verbalno ali napisano pojasnilo ali zagovor rezultata, se zahteva po posredovanju poveča. 


\section{Matematiziranje}

Nekatere naloge ne zahtevajo matematizacije - to pomeni, da je problem že opredeljen v matematični obliki ali pa odnos med modelom in situacijo, ki jo predstavlja, ni potreben za rešitev problema. Zahteva po matematizaciji se lahko pojavi pri najmanj kompleksni obliki, ko mora dijak interpretirati in neposredno izpeljati rešitev iz danega modela ali neposredno pretvoriti situacijo v matematično (npr. oblikovati koncept situacije na smiseln način, opredeliti in izbrati pomembne spremenljivke, zbrati pomembne meritve in/ali diagrame). Zahtevnost procesa matematizacije se povečuje $z$ dodatnimi zahtevami po prilagajanju ali uporabi danega modela z željo, da bi dijak zajel spremenjene okoliščine ali interpretiral odnose, o katerih sklepa; izbere znani model v omejenih in jasno začrtanih mejah; ali ustvari model, v katerem so zahtevane spremenljivke, odnosi in omejitve eksplicitni in jasni. Na višjem nivoju, pa je zahteva po matematizaciji povezana s potrebo po tem, da bi dijak ustvaril ali interpretiral model v situaciji, kjer je treba številne domneve, spremenljivke, odnose in omejitve prepoznati in opredeliti ter preveriti, ali model ustreza zahtevam naloge, ali evalvirati in primerjati modele.

\section{Predstavljanje}

Ta matematična zmožnost se aktivira na najnižji ravni, ko je treba neposredno obdelati dani prikaz, denimo preiti od besedila $\mathrm{k}$ številkam ali prebrati vrednost neposredno $\mathrm{z}$ grafa ali tabele. Kognitivno zahtevnejše naloge s prikazi pa zahtevajo izbor in interpretacijo določenega podatka na višjem nivoju zahtevnosti, kot npr. zahteva po pretvorbi med dvema prikazoma ali uporaba dveh ali več prikazov skupaj s situacijo, kar vključuje tudi spreminjanje prikaza. Kognitivna zahteva višje zahtevnostne stopnje je opredeljena s potrebo po razumevanju in uporabi nestandardnih prikazov, ki zahtevajo precejšnje razčlenjevanje in interpretiranje; na primer oblikovanje prikaza, ki ujame ključne vidike kompleksne situacije oziroma primerja ali ovrednoti različne prikaze.

\section{Sklepanje in utemeljevanje}

Pri nalogah nižje zahtevnostne stopnje je za aktivacijo te zmožnosti zahtevano sklepanje, ki lahko vključuje preprosto upoštevanje danih navodil. Na nekoliko višji zahtevnostni stopnji zahtevajo naloge nekaj refleksije, ki omogoča povezovanje različnih informacij, da bi lahko sklepali (npr. povezovanje ločenih komponent, ki so del problema ali uporaba neposrednega sklepanja pri enem vidiku problema). Na višjem nivoju zahtevajo naloge analizo informacij, da bi sledili ali ustvarili utemeljitev v več korakih, da bi povezali več spremenljivk ali sklepali na podlagi povezanih podatkovnih virov. 
Oblikovanje strategij

$\mathrm{V}$ nalogah relativno nizke zahtevnostne stopnje za to zmožnost pogosto zadostujejo neposredna dejanja, pri katerih je potrebna strategija očitna ali celo zapisana. Na višjem nivoju zahtevnosti se je treba odločati o primerni strategiji, s katero uporabimo pomembne dane informacije, da bi prišli do zaključka. Kognitivne zahteve se povečajo s potrebo po oblikovanju in pripravi strategije, $s$ katero dane podatke pretvorimo, da pridemo do zaključka. Še bolj zahtevne naloge zahtevajo izdelavo izpopolnjene strategije, s katero poiščemo izčrpno rešitev, posplošen zaključek, lahko pa ovrednotimo ali primerjamo različne možne strategije.

\section{Uporaba simbolnega, formalnega in tehniškega jezika in operacij}

Zahteva po aktivaciji te sposobnosti se od naloge do naloge zelo razlikuje. Pri najpreprostejših nalogah ni potrebno aktivirati nobenih matematičnih pravil ali simbolnih izrazov, ki presegajo osnovne aritmetične izračune, saj reševanje nalog poteka $z$ majhnimi in preprostimi sledljivimi številkami. Delo z zahtevnejšimi nalogami lahko vključuje zaporedje aritmetičnih izračunov ali pa neposredno uporabo preprostih funkcijskih odnosov, ki so bodisi eksplicitni bodisi implicitni (npr. znani linearni odnosi); uporabo formalnih matematičnih simbolov (npr. substitucija ali aritmetični izračuni, ki vključujejo ulomke in decimalna števila); aktivacijo in neposredno uporabo matematične definicije ali simbolnega koncepta (npr. z algebraičnim premetavanjem formule), aktivacijo in uporabo matematičnih pravil, definicij, konvencij, postopkov ali formul z uporabo mnogoterih odnosov ali simbolnih konceptov. Še višji nivo zahtevnosti opredeljuje uporaba formalnih matematičnih postopkov $\mathrm{v}$ več zaporednih korakih, sproščeno delo $\mathrm{s}$ funkcionalnimi algebraičnimi odnosi in uporaba matematične tehnike in znanja, ki prinese rezultate.

\section{Uporaba matematičnih orodij}

Naloge in dejavnosti, ki vključujejo relativno nižjo zahtevnostno stopnjo te zmožnosti, lahko zahtevajo neposredno uporabo znanih orodij, kot so merilni inštrumenti, in sicer v tistih situacijah, v katerih ta orodja uporabljamo. Višji nivo zahtevnosti se pojavi takrat, ko uporabljamo orodje, ki zahteva zaporedje postopkov ali povezovanje različnih podatkov z uporabo orodja, posebno takrat, ko orodje slabo poznamo ali ko nam je situacija, v kateri uporabljamo orodje, manj znana. Še višja zahtevnostna stopnja je vidna ta$\mathrm{krat}$, ko naj bi orodje uporabili, da bi obdelali in povezali mnogotere podatkovne elemente, ko je uporaba orodja potrebna $\mathrm{v}$ situaciji, ki se razlikuje od sicer znane uporabe, ko je 
orodje kompleksno in ko je potrebno razmisliti, da bi razumeli in evalvirali prednosti in pomanjkljivosti orodja.

\section{Matematični konteksti}

Pomemben vidik matematične pismenosti je tudi ta, da z matematiko rešujemo problem v določenem kontekstu. Kontekst je določen vidik posameznikovega sveta, v katerega so umeščeni problemi. Izbira ustreznih matematičnih strategij in prikazov je pogosto odvisna od konteksta, v katerem se pojavi problem. Za raziskavo PISA je pomembno, da uporabimo široko paleto različnih kontekstov. To nam omogoča, da se povežemo s kar najširšim možnim razponom individualnih interesov in s celo vrsto situacij, v katerih se znajdejo posamezniki v 2 I. stoletju.

V okviru raziskave PISA 2012 poznamo štiri kategorije kontekstov, v katere tudi glede na to dimenzijo razvrščamo naloge:

- Osebni - Problemi, uvrščeni v kategorijo osebnega konteksta, so osredinjeni na dejavnosti posameznika, njegove družine ali vrstniške skupine. Konteksti, ki veljajo za osebne, vključujejo (vendar niso omejeni na) pripravljanje hrane, nakupovanje, igre, osebno zdravje, osebni prevoz, šport, potovanje, osebno razporeditev časa in osebne finance. Na primer, že omenjena naloga Pice je postavljena v osebni kontekst, saj v nalogi zasledimo vprašanje, katera pica je za kupca cenovno ugodnejša.

- Poklicni - Problemi, uvrščeni v kategorijo poklicnega konteksta, so osredinjeni na svet dela. Naloge, ki odražajo poklicni kontekst, lahko vključujejo (vendar niso omejene na) merjenje, cene in naročanje materialov za gradnjo, izdajanje računov, nadzor kakovosti, sestavljanje urnika/inventarja, oblikovanja/arhitekture in z delom povezano sprejemanje odločitev. Poklicni konteksti so lahko povezani s katero koli izobrazbeno stopnjo delovne sile, od nekvalificiranega dela do najvišjih stopenj zaposlitve, čeprav morajo biti naloge v raziskavi PISA dostopne i 5 -letnim dijakom. Nalogo Pice, v kateri smo predstavili situacijo z vidika prodajalca pic, ne kupca, bi uvrstili v kategorijo nalog s poklicnim kontekstom.

- Družbeni - Problemi, uvrščeni v kategorijo problemov v družbenem kontekstu, so osredinjeni na posameznikovo skupnost (bodisi krajevno, nacionalno ali globalno). Vključujejo (vendar niso omejeni na) volilne sisteme, javni prevoz, vlado, javno politiko, demografijo, oglaševanje, nacionalne statistične podatke in gospodarstvo. Čeprav so posamezniki tudi osebno vključeni v omenjene dejavnosti, 
je kategorija družbenega konteksta osredinjena na probleme z vidika skupnosti. Že omenjena naloga Rock koncert je zgled naloge, ki je umeščena v družbeni kontekst, saj je postavljena v okvir organizacije rock koncerta, čeprav lahko hkrati črpa osebno izkušnjo posameznika, ki se znajde $\mathrm{v}$ množici.

- Znanstveni - Problemi, uvrščeni v kategorijo znanstvenega konteksta, so povezani $z$ uporabo matematike $v$ svetu narave ter vprašanji in temami, ki so povezane z znanostjo in tehnologijo. Ta kontekst lahko vključuje (vendar ni omejen na) področja, kot so vreme ali podnebje, ekologija, medicina, znanost o vesolju, genetika, meritve in svet matematike. V znanstveni kontekst spadajo tudi naloge, pri katerih so vsi elementi del sveta matematike.

Naloge v raziskavi PISA so urejene tako, da je najprej navedeno skupno uvodno besedilo, temu pa sledijo različna vprašanja. Pogosto se zgodi, da vsa vprašanja spadajo v isti kontekst. Obstajajo pa tudi izjeme; denimo, da je besedilo naloge pri enem vprašanju obravnavano z osebnega vidika, v drugem pa z družbenega.

$\mathrm{Z}$ uporabo kontekstualnih kategorij raziskava PISA zagotavlja, da ugotavljanje matematične pismenosti odraža široko paleto uporabe matematike, od vsakdanje osebne rabe do znanstvenih izzivov globalnih problemov. Pomembno je tudi to, da vsak kontekstualni sklop obsega naloge različnih zahtevnostnih stopenj.

Pri opredeljevanju kontekstov, ki so pomembni, je bilo ključnega pomena zavedanje, da je namen ugotavljanja matematične pismenosti tudi spremljanje znanja matematičnih vsebin, procesov in sposobnosti ter zmožnosti, ki so jih dijaki usvojili do I 5 . leta starosti. Konteksti nalog so bili torej izbrani glede na to, kakšen pomen imajo v dijakovih zanimanjih in življenju ter glede na zahteve, s katerimi se bo srečal, ko bo vstopal v družbo kot ustvarjalen, dejaven in razmišljujoč državljan. O tem, katere teme so pomembne, presojajo nacionalni koordinatorji projekta iz držav, sodelujočih v raziskavi PISA. 


\section{Porazdelitev nalog glede na vsebino, proces in kontekst}

Glede na opredelitev matematične pismenosti so torej naloge umeščene $\mathrm{v}$ določen kontekst in obsegajo uporabo pomembnih matematičnih konceptov, znanja, razumevanja in spretnosti (znanje matematičnih vsebin) na nivoju, ki ustreza I5-letnim dijakom, kakor smo opisali zgoraj. Do sedaj smo predstavili strukturo raziskave in vsebino, pomembno pa je, da instrumentarij vsebuje ustrezno zastopanost nalog, ki odražajo izhodišča matematične pismenosti.

\section{Porazdelitev nalog glede na vsebinske kategorije}

Matematične naloge $\mathrm{v}$ raziskavi PISA so bile izbrane tako, da odražajo znanje matematičnih vsebin, ki smo jih opisali zgoraj. Naloge, ki so bile izbrane, so razdeljene v štiri vsebinske sklope, kakor kaže spodnja tabela. Naloge so porazdeljene glede na vsebinski sklop enakomerno, saj so vsi štirje vsebinski sklopi enako pomembni za ustvarjalne, dejavne in razmišljujoče državljane.

Tabela 3: Porazdelitev matematičnih nalog glede na vsebinske kategorije

\begin{tabular}{|l|c|}
\hline \multicolumn{1}{|c|}{ Vsebinskisklop } & Odstoteknalog (\%) \\
\hline Spremenljivke in odnosi & približno 25 \\
\hline Liki in telesa & približno 25 \\
\hline Količine & približno 25 \\
\hline Verjetnost in delos podatki & približno 25 \\
\hline Skupaj & Ioo \\
\hline
\end{tabular}


Pomembno je omeniti, da imajo naloge v vsakem vsebinskem sklopu več zahtevnostnih stopenj.

\section{Porazdelitev nalog glede na matematične procese}

Poleg vsebine so bile naloge pri ugotavljanju znanja matematike v raziskavi PISA 2012 uvrščene v eno od treh kategorij matematičnih procesov. Cilj je bil doseči ravnovesje med dvema procesoma: med tistim, ki omogoča povezovanje med resničnim svetom in svetom matematike, in tistim, ki od dijaka zahteva zmožnost reševanja matematično formuliranega problema v kontekstu realnega problema.

Tabela 4: Porazdelitev matematičnih nalog glede na matematične procese

\begin{tabular}{|l|c|}
\hline \multicolumn{1}{|c|}{ Kategorija matematičnih procesov } & Odstoteknalog (\%) \\
\hline Matematično formuliranje situacij & približno 25 \\
\hline Uporaba matematičnih konceptov, dejstev, postopkov in sklepanje & približno 50 \\
\hline Interpretiranje, (uporaba) in evalviranje matematičnih rezultatov & približno 25 \\
\hline Skupaj & Ioo \\
\hline
\end{tabular}

Tudi v teh kategorijah se naloge nahajajo na različnih stopnjah zahtevnosti.

\section{Porazdelitev nalog glede na kontekstualne kategorije}

V raziskavi PISA 2012 je vsaka naloga umeščena v enega od štirih kontekstualnih sklopov. V štiri vsebinske sklope so naloge porazdeljene, kot je prikazano v spodnji tabeli. Zaradi takšne uravnotežene porazdelitve ni noben kontekstualni sklop prevladujoč, zato lahko dijaki rešujejo naloge, ki obravnavajo različne interese in situacije, s katerimi se bodo srečali v življenju.

Tabela s: Porazdelitev matematičnih nalog glede na kontekstualne kategorije

\begin{tabular}{|l|c|}
\hline \multicolumn{1}{|c|}{ Kontekstualne kategorije } & Odstoteknalog (\%) \\
\hline Osebni & približno 25 \\
\hline Poklicni & približno 25 \\
\hline Družbeni & približno 25 \\
\hline Znanstveni & približno 25 \\
\hline Skupaj & I0o \\
\hline
\end{tabular}

Tudi v teh kategorijah se naloge nahajajo na različnih stopnjah zahtevnosti. 


\section{Vprašalniki za dijakinje in dijake}

$Z$ rezultati raziskave PISA želimo dobiti pomembne podatke za snovalce izobraževalne politike v sodelujočih državah tako glede učnih dosežkov kot tudi posrednih (drugih) dejavnikov, ki na le-te učinkujejo. V ta namen v okviru raziskave PISA uporabljamo dodatne vprašalnike za dijakinje in dijake (izpolnjevanje traja približno 35 minut) in tudi vprašalnike za šole (izpolnjevanje traja približno 40 minut), ki jih izpolnjujejo ravnatelji.

Omenjeni vprašalniki so ključnega pomena za analizo dosežkov učencev in so povezani z več spremljajočimi podatki na ravni učencev in ravni šol, ki se nanašajo na:

- družinsko ozadje učencev, vključno z gospodarskim, socialnim in kulturnim kapitalom;

- učenje matematike in dijakove matematične izkušnje;

- dijakove izkušnje z reševanjem problemov;

- kakovost človeških virov na šoli in materialne vire, način organiziranja in financiranja šole (javna ali zasebna šola), procese sprejemanja odločitev in prakse zaposlovanja;

- vsebino učnih praks, vključno $s$ tipi in strukturami izobraževalnih sistemov, velikostjo razreda in oblikami sodelovanja staršev;

- strategije samostojnega učenja, motivacijo in postavljanje ciljev, kognitivne mehanizme, kontrolne strategije, naklonjenost različnim tipom učnih situacij, sloge učenja in socialne spretnosti, potrebne za sodelovanje ter učenje;

- oblike učenja in poučevanja pri matematiki;

- splošno uporabo in razpoložljivost informacijsko-komunikacijske tehnologije; 
- odnos dijaka do računalnikov;

- $\quad$ izobraževanje v prihodnosti ter morebitno pomoč pri jezikovnem izobraževanju.

\section{Zanimanje za matematiko in odnos do matematičnih vsebin}

Posameznikova naravnanost, prepričanja in čustva igrajo pomembno vlogo pri zanimanju za in odzivanju na matematiko na splošno ter pri uporabi matematike v življenju. Dijaki, ki so samozavestnejši pri matematiki, bodo matematiko uporabljali pogosteje kot drugi in v različnih kontekstih, s katerimi se srečujejo. Dijaki, ki so pozitivno naravnani do matematike, se je bolje učijo kot dijaki, ki jih matematika spravlja v stisko. Eden od ciljev poučevanja matematike je torej razvijanje pozitivne naravnanosti, prepričanj in čustev dijakov, s čimer bodo lažje in uspešneje uporabljali matematiko, kakršno poznajo, in se je naučili več, kar jim bo koristilo v osebnem in družbenem pogledu. Temu smo pri ugotavljanju matematične pismenosti v raziskavi PISA 2012 namenili več pozornosti, saj trdimo, da je razvijanje pozitivne naravnanosti, čustev in prepričanj do matematike dragocen dosežek šolanja, ki omogoča, da dijaki postanejo dovzetni za uporabo matematike v življenju. Prav razvoj pozitivne naravnanosti, čustev in prepričanj pa lahko prispeva $\mathrm{k}$ razlikam (oz. je lahko njihov vzrok) pri dosežkih matematične pismenosti. Vprašalnik v raziskavi PISA torej vključuje tudi vprašanja, ki so povezana s temi naravnanostmi.

Zanimanje za matematiko je sestavljeno iz delov, ki so povezani s sedanjo in prihodnjo dejavnostjo. Pomembna vprašanja so osredinjena na dijakovo zanimanje za matematiko v šoli, ali ta učni predmet pojmuje kot koristen v resničnem življenju, prav tako pa na njegove namene, da bi študiral matematiko in si izbral poklicno pot, v kateri bi se z matematiko ukvarjal. S tem področjem se v mednarodni skupnosti veliko ukvarjajo, saj v številnih sodelujočih državah opažajo padec odstotkov dijakov, ki si izberejo z matematiko povezan študij, hkrati pa čedalje bolj narašča potreba po diplomantih s teh področij.

Pripravljenost dijakov, da se ukvarjajo z matematiko, je povezana $\mathrm{z}$ njihovo naravnanostjo, čustvi in samoprepričanji, zaradi katerih napredujejo ali pa ne napredujejo v matematični pismenosti. Dijaki, ki uživajo v reševanju matematičnih nalog in se jih lotevajo samozavestno, bodo matematiko radi uporabljali pri razmišljanju o situacijah, s katerimi se srečujejo v različnih vidikih življenja, tako v šoli kot izven šole. Del raziskave PISA, ki je povezan s tem področjem, vključuje tudi preverjanje naravnanosti in čustev, kot so uživanje, samozavest in odsotnost strahu pred matematiko, ter prepričanosti vase in učne samoučinkovitosti. Nedavna analiza I5-letnikov v Avstraliji, ki so se slabo odrezali v predraziskavi PISA 20 2, je pokazala, da tisti, ki »prepoznavajo vrednost matematike za prihodnji 
uspeh, ta uspeh tudi dosežejo, to pa vključuje tudi zadovoljstvo na več vidikih osebnega življenja, prav tako pa v njihovi prihodnosti in na poklicni poti« (Thomson in Hillman, 20IO: 3I). Študija tudi kaže, da osredinjenje na praktično uporabnost matematike v vsakdanjem življenju lahko izboljša dosežke za tiste dijake, ki so v raziskavi PISA na testu matematične pismenosti dosegli nizke rezultate. 



\section{Naloge iz matematične pismenosti}

V nadaljevanju predstavljamo naloge iz testa PISA za preverjanje matematične pismenosti, ki so bile uporabljene v predraziskavi in raziskavi PISA 2012.

Pri vsaki nalogi najprej navajamo uvodno besedilo naloge, nato vprašanja, ki sledijo, temu pa sledi še kodirna shema pravilnih in nepravilnih odgovorov za določeno vprašanje. Pri vsaki nalogi navajamo tudi vsebino, proces in kontekst, $\mathrm{v}$ katerega se naloga uvršča. 
USB KLJUČ

USB ključ je majhna prenosna računalniška naprava za shranjevanje podatkov.

Ivan ima USB ključ za shranjevanje glasbe in fotografij. Njegov USB ključ ima I GB (Iooo $\mathrm{MB})$ prostora. Spodnji graf prikazuje trenutno zasedenost njegovega USB ključa.

\section{Zasedenost USB kjjuča}

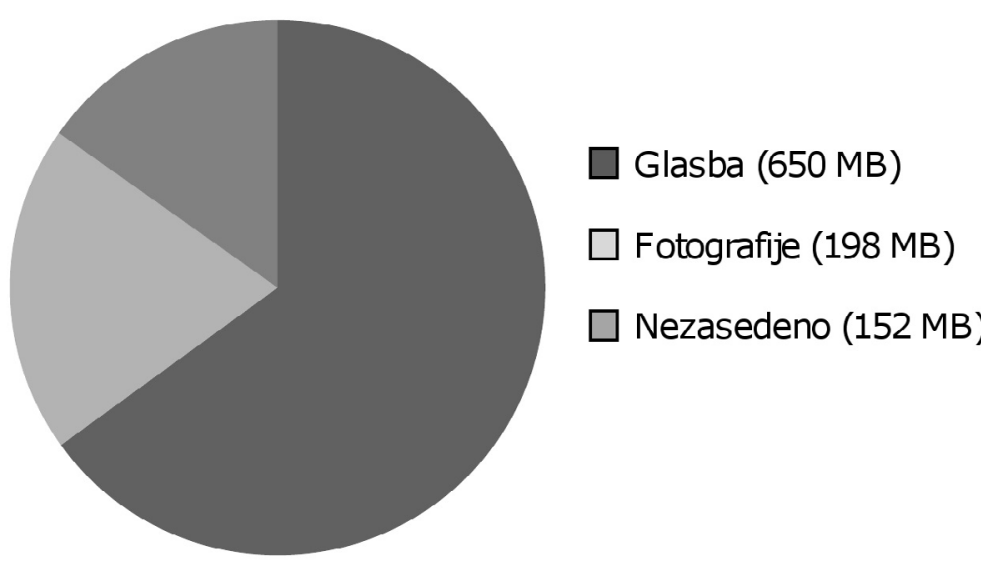




\section{I. vprašanje: USB KLJUČ}

Ivan bi rad prenesel album fotografij v velikosti $350 \mathrm{MB}$ na svoj USB ključ, vendar ima na njem premalo nezasedenega prostora. Noče izbrisati fotografij, od glasbenih albumov pa bi izbrisal največ dva.

$\mathrm{Na}$ Ivanovem USB ključu so shranjeni glasbeni albumi naslednjih velikosti:

\begin{tabular}{|c|c|}
\hline Album & Velikost \\
\hline Album 1 & $100 \mathrm{MB}$ \\
\hline Album 2 & $75 \mathrm{MB}$ \\
\hline Album 3 & $80 \mathrm{MB}$ \\
\hline Album 4 & $55 \mathrm{MB}$ \\
\hline Album 5 & $60 \mathrm{MB}$ \\
\hline Album 6 & $80 \mathrm{MB}$ \\
\hline Album 7 & $75 \mathrm{MB}$ \\
\hline Album 8 & $125 \mathrm{MB}$ \\
\hline
\end{tabular}

Bo imel Ivan na svojem USB ključu dovolj prostora, da doda album s fotografijami, če bo izbrisal največ dva glasbena albuma? Obkroži "Da" ali "Ne" in z izračunom podpri svoj odgovor.

Odgovor: $\mathrm{Da} / \mathrm{Ne}$ 
USB KLJUČ: TOČKOVANJE 1

\section{NAMEN VPRAŠANJA:}

Opis: Primerjati in izračunati vrednosti, da bi zadostili danim merilom Matematično področje: Količine

Kontekst: Osebni

Proces: Interpretiranje

Pravilen odgovor

Koda 1: Eksplicitno ali implicitno odgovori z DA IN navede katerokoli kombinacijo dveh albumov, ki skupaj zasedata $198 \mathrm{MB}$ prostora ali več.

- Izbrisati mora $198 \mathrm{MB}$ (350-152), tako da lahko izbriše katerakoli dva glasbena albuma, ki skupaj zasedata več kot $198 \mathrm{MB}$, na primer albuma 1 in 8 .

- Ja, lahko izbriše albuma 7 in 8 , saj bo tako dobil razpoložljiv prostor 152 $+75+125=352 \mathrm{MB}$.

Nepravilen odgovor

Koda 0: Drugi odgovori.

Koda 9: Ni odgovora. 
2. vprašanje: USB KLJUČ

V naslednjih tednih Ivan izbriše nekaj fotografij in glasbe, doda pa nove datoteke s fotografijami in z glasbo. V spodnji tabeli je prikazana nova zasedenost njegovega ključa:

\begin{tabular}{|l|c|}
\hline Glasba & $550 \mathrm{MB}$ \\
\hline Fotografije & $338 \mathrm{MB}$ \\
\hline Nezasedeno & $112 \mathrm{MB}$ \\
\hline
\end{tabular}

Brat mu da nov USB ključ s kapaciteto 2 GB (2000 MB), ki je popolnoma prazen. Ivan prenese vsebino starega USB ključa na novega.

Kateri od naslednjih grafov predstavlja zasedenost novega USB ključa? Obkroži A, B, C ali D.

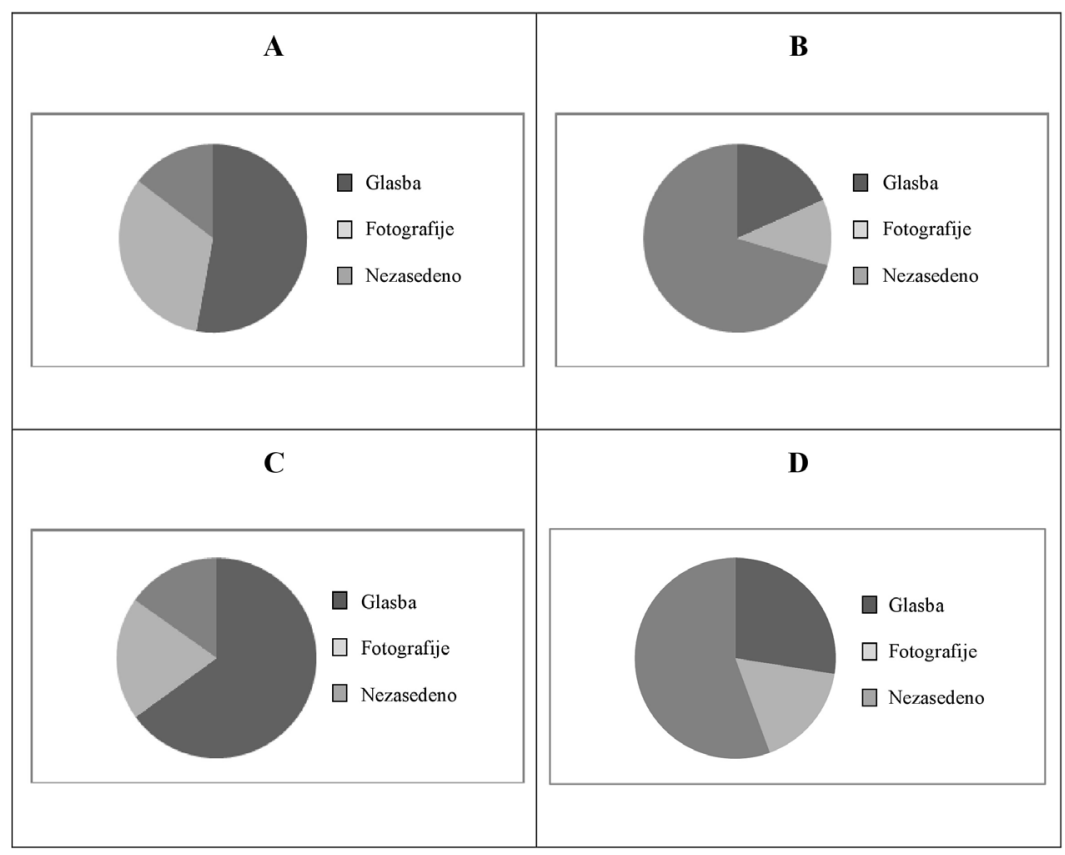


USB KLJUČ: TOČKOVANJE 2

\section{NAMEN VPRAŠANJA:}

Opis: Razumeti povezanost med jezikom, v katerem je problem zastavljen, ter simbolnim in formalnim jezikom, ki je potreben za matematično predstavitev problema

Matematično področje: Verjetnost in delo s podatki

Kontekst: Osebni

Proces: Interpretiranje

Pravilen odgovor

Koda 1: D

Nepravilen odgovor

Koda 0: Drugi odgovori.

Koda 9: Ni odgovora. 


\section{PREDVAJALNIKI Z NAPAKO}

Podjetje Elektrik izdeluje dve vrsti elektronskih naprav: video in zvočne predvajalnike. Ob koncu proizvodnega dne predvajalnike testirajo ter tiste $\mathrm{z}$ napako odstranijo in pošljejo $\mathrm{v}$ popravilo.

V spodnji tabeli je prikazano povprečno število dnevno izdelanih predvajalnikov obeh vrst in povprečen odstotek dnevno izdelanih predvajalnikov z napako.

\begin{tabular}{|l|c|c|}
\hline Vrsta predvajalnika & $\begin{array}{c}\text { Povprečno število dnevno } \\
\text { izdelanih predvajalnikov }\end{array}$ & $\begin{array}{c}\text { Povprečen odstotek } \\
\text { dnevno izdelanih } \\
\text { predvajalnikov z napako }\end{array}$ \\
\hline Video predvajalniki & 2000 & $5 \%$ \\
\hline Zvočni predvajalniki & 6000 & $3 \%$ \\
\hline
\end{tabular}

1. vprašanje: PREDVAJALNIKI Z NAPAKO

Spodaj so tri trditve o dnevni proizvodnji v podjetju Elektrik. So te trditve pravilne?

Pri vsaki trditvi obkroži "Da" ali "Ne".

\begin{tabular}{|l|c|}
\hline Trditev & $\begin{array}{c}\text { Ali je ta trditev } \\
\text { pravilna? }\end{array}$ \\
\hline $\begin{array}{l}\text { Tretjina dnevno izdelanih predvajalnikov je video } \\
\text { predvajalnikov. }\end{array}$ & $\mathrm{Da} / \mathrm{Ne}$ \\
\hline $\begin{array}{l}\text { V vsaki seriji } 100 \text { izdelanih video predvajalnikov je } \\
\text { natanko } 5 \text { takih z napako. }\end{array}$ & $\mathrm{Da} / \mathrm{Ne}$ \\
\hline $\begin{array}{l}\text { Če med dnevno izdelanimi zvočnimi predvajalniki } \\
\text { naključno izberejo enega za testiranje, je verjetnost, da ga } \\
\text { bo treba popraviti, enaka } 0,03 .\end{array}$ & $\mathrm{Da} / \mathrm{Ne}$ \\
\hline
\end{tabular}


PREDVAJALNIKI Z NAPAKO: TOČKOVANJE 1

\section{NAMEN VPRAŠANJA:}

Opis: Interpretirati statistično informacijo, ki vključuje verjetnost Matematično področje: Verjetnost in delo s podatki

Kontekst: Poklicni

Proces: Formuliranje

Pravilen odgovor

Koda 1: Trije pravilni odgovori: $\mathrm{Ne}, \mathrm{Ne}, \mathrm{Da}, \mathrm{v}$ tem vrstnem redu.

Nepravilen odgovor

Koda 0: Drugi odgovori.

Koda 9: Ni odgovora. 
2. vprašanje: PREDVAJALNIKI Z NAPAKO

Eden od preizkuševalcev predvajalnikov trdi naslednje:

"V povprečju pošljemo dnevno v popravilo več video predvajalnikov kot pošljemo dnevno v popravilo zvočnih predvajalnikov."

Zapiši, ali je preizkuševalčeva trditev pravilna ali ne. Svoj odgovor podpri z matematično utemeljitvijo. 
PREDVAJALNIKI Z NAPAKO: TOČKOVANJE 2

\section{NAMEN VPRAŠANJA:}

Opis: Interpretirati statistično informacijo, ki vključuje verjetnost Matematično področje: Verjetnost in delo s podatki

Kontekst: Poklicni

Proces: Interpretiranje

Pravilen odgovor

Koda 1: Ustrezno pojasnilo, zakaj preizkuševalec nima prav.

- Preizkuševalec nima prav; 5 \% od 2000 je 100, toda $3 \%$ od 6000 je 180. Torej v povprečju v popravilo pošljejo 180 zvočnih predvajalnikov, kar je večje od povprečja 100 video predvajalnikov, ki jih pošljejo v popravilo.

- Preizkuševalec nima prav; video predvajalnikov z napako je $5 \%$, kar je malce manj kot dvakrat več od odstotka zvočnih predvajalnikov z napako. Toda izdelajo 6000 zvočnih predvajalnikov, kar je trikrat več od števila zvočnih predvajalnikov, zato je dejansko število zvočnih predvajalnikov, ki jih pošljejo v popravilo, večje.

Nepravilen odgovor

Koda 0: Drugi odgovori.

Koda 9: Ni odgovora. 


\section{3. vprašanje: PREDVAJALNIKI Z NAPAKO}

Tudi podjetje Tronik izdeluje video in zvočne predvajalnike. Ob koncu proizvodnega dne predvajalnike podjetja Tronik testirajo ter tiste z napako odstranijo in pošljejo v popravilo.

Spodnji tabeli primerjata povprečno število dnevno izdelanih predvajalnikov obeh vrst in povprečen odstotek dnevno izdelanih predvajalnikov z napako v obeh podjetjih.

\begin{tabular}{|l|l|l|}
\hline Podjetje & $\begin{array}{l}\text { Povprečno število dnevno } \\
\text { izdelanih video predvajalnikov }\end{array}$ & $\begin{array}{l}\text { Povprečen dnevni odstotek } \\
\text { predvajalnikov z napako }\end{array}$ \\
\hline Elektrik & 2000 & $5 \%$ \\
\hline Tronik & 7000 & $4 \%$ \\
\hline
\end{tabular}

\begin{tabular}{|l|l|l|}
\hline Podjetje & $\begin{array}{l}\text { Povprečno število dnevno } \\
\text { izdelanih zvočnih } \\
\text { predvajalnikov }\end{array}$ & $\begin{array}{l}\text { Povprečen odstotek dnevno } \\
\text { izdelanih predvajalnikov z } \\
\text { napako }\end{array}$ \\
\hline Elektrik & 6000 & $3 \%$ \\
\hline Tronik & 1000 & $2 \%$ \\
\hline
\end{tabular}

Katero od obeh podjetij, Elektrik ali Tronik, ima manjši odstotek skupno izdelanih predvajalnikov z napako? Zapiši svoj izračun, v njem pa uporabi podatke iz zgornjih tabel. 
PREDVAJALNIKI Z NAPAKO: TOČKOVANJE 3

\section{NAMEN VPRAŠANJA:}

Opis: Interpretirati statistično informacijo, ki vključuje verjetnost Matematično področje: Verjetnost in delo s podatki

Kontekst: Poklicni

Proces: Formuliranje

Pravilen odgovor

Koda 1: Ustrezno matematično pojasnilo za izbor podjetja Elektrik.

- Podjetje Elektrik. Ker 5 \% od 2000 je 100, 3 \% od 6000 je 180, torej v podjetju Elektrik v povprečju pošljejo v popravilo 280 dnevno izdelanih predvajalnikov; pri 8000 predvajalnikih pomeni 280 predvajalnikov 3,5 $\%$ predvajalnikov z napako. Podoben izračun za podjetje Tronik pokaže, da imajo 3,75 \% predvajalnikov z napako. [Za pravilen odgovor je treba zapisati izračun odstotkov.]

Nepravilen odgovor

Koda 0: Drugi odgovori.

Koda 9: Ni odgovora. 
NAKUP STANOVANJA

To je tloris stanovanja, ki ga želijo Gregorjevi starši kupiti prek nepremičninske agencije.

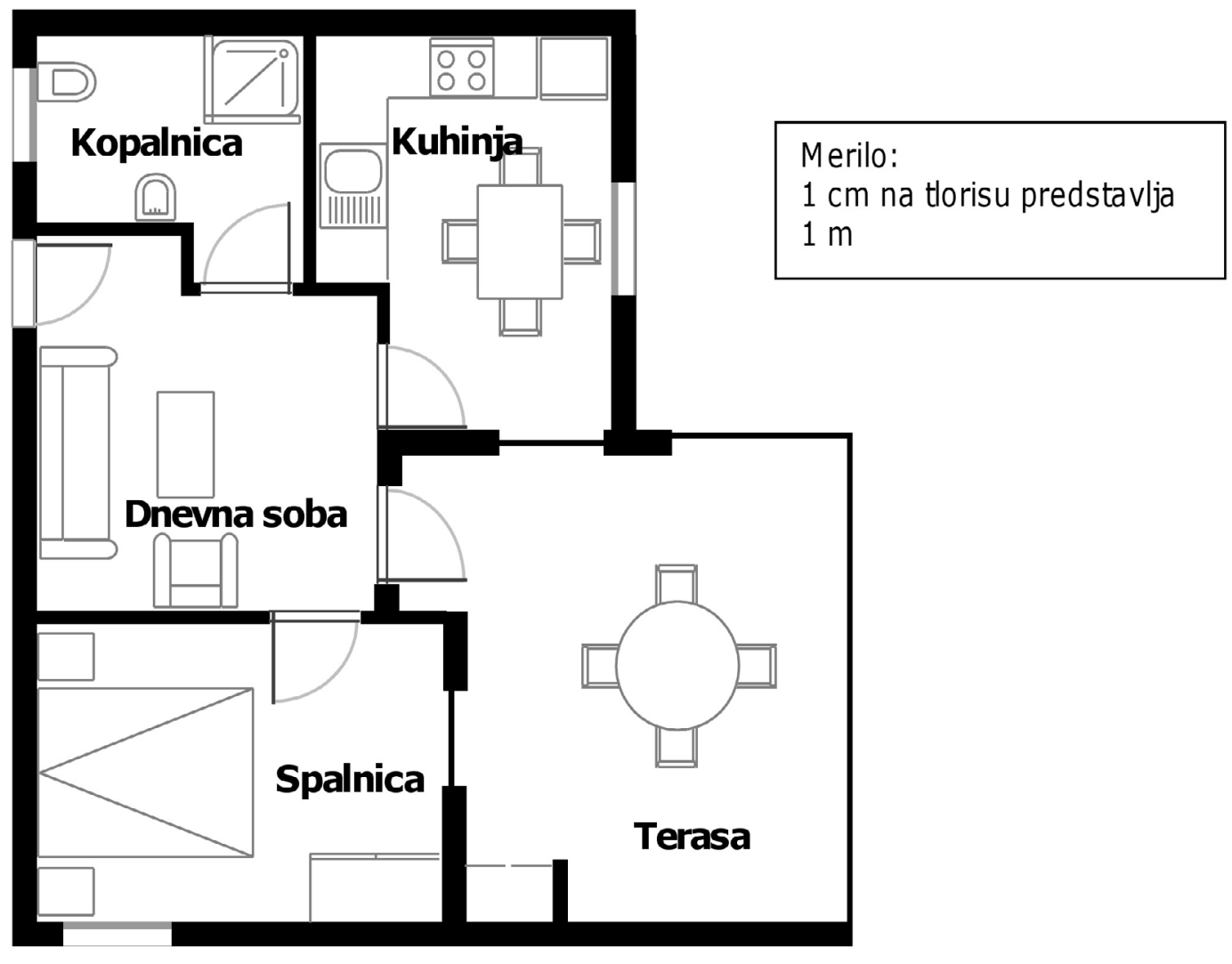

I. vprašanje: NAKUP STANOVANJA

Celotno talno površino (ploščino) stanovanja (vključno s teraso in stenami) lahko oceniš tako, da izmeriš velikost vsakega prostora, izračunaš njegovo površino in sešteješ površine vseh prostorov.

Vendar pa lahko talno površino oceniš na učinkovitejši način, tako da izmeriš samo 4 dolžine. Na zgornjem tlorisu označi štiri dolžine, ki jih potrebuješ, da bi ocenil/-a celotno talno površino stanovanja. 
NAKUP STANOVANJA: TOČKOVANJE 1

\section{NAMEN VPRAŠANJA:}

Opis: Uporabiti prostorsko sklepanje (ali katero drugo metodo) in izbrati tloris, kjer lahko površino ocenimo z najmanjšim številom dolžin

Matematično področje: Liki in telesa

Kontekst: Osebni

Proces: Formuliranje

Pravilen odgovor

Koda 1: Označi štiri dimenzije, ki so potrebne za oceno talne površine stanovanja v
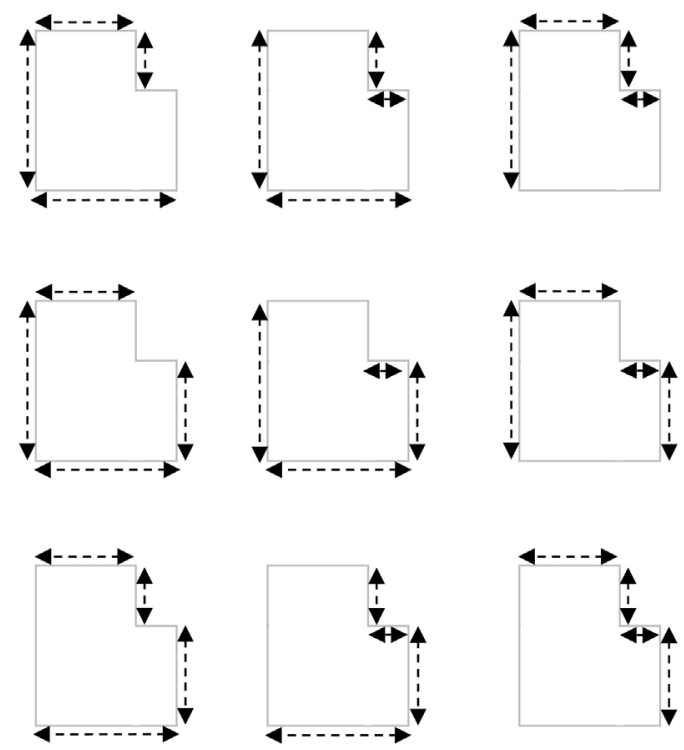

tlorisu. Možnih je 9 načinov, ki so prikazani spodaj.

- $\mathrm{A}=(9,7 \mathrm{~m} \cdot 8,8 \mathrm{~m})-(2 \mathrm{~m} \cdot 4,4 \mathrm{~m}), \mathrm{A}=76,56 \mathrm{~m}^{2}$ [Očitno je za izmero in izračun zabtevane površine uporabil 4 dolžine]

Nepravilen odgovor

Koda 0: Drugi odgovori.

Koda 9: Ni odgovora. 


\section{PRODAJALNA SLADOLEDA}

Maša prenavlja svojo prodajalno sladoleda. Spodaj je tloris prodajalne.

Strežni del je obdan s pultom.

\section{Vhodna vrata}

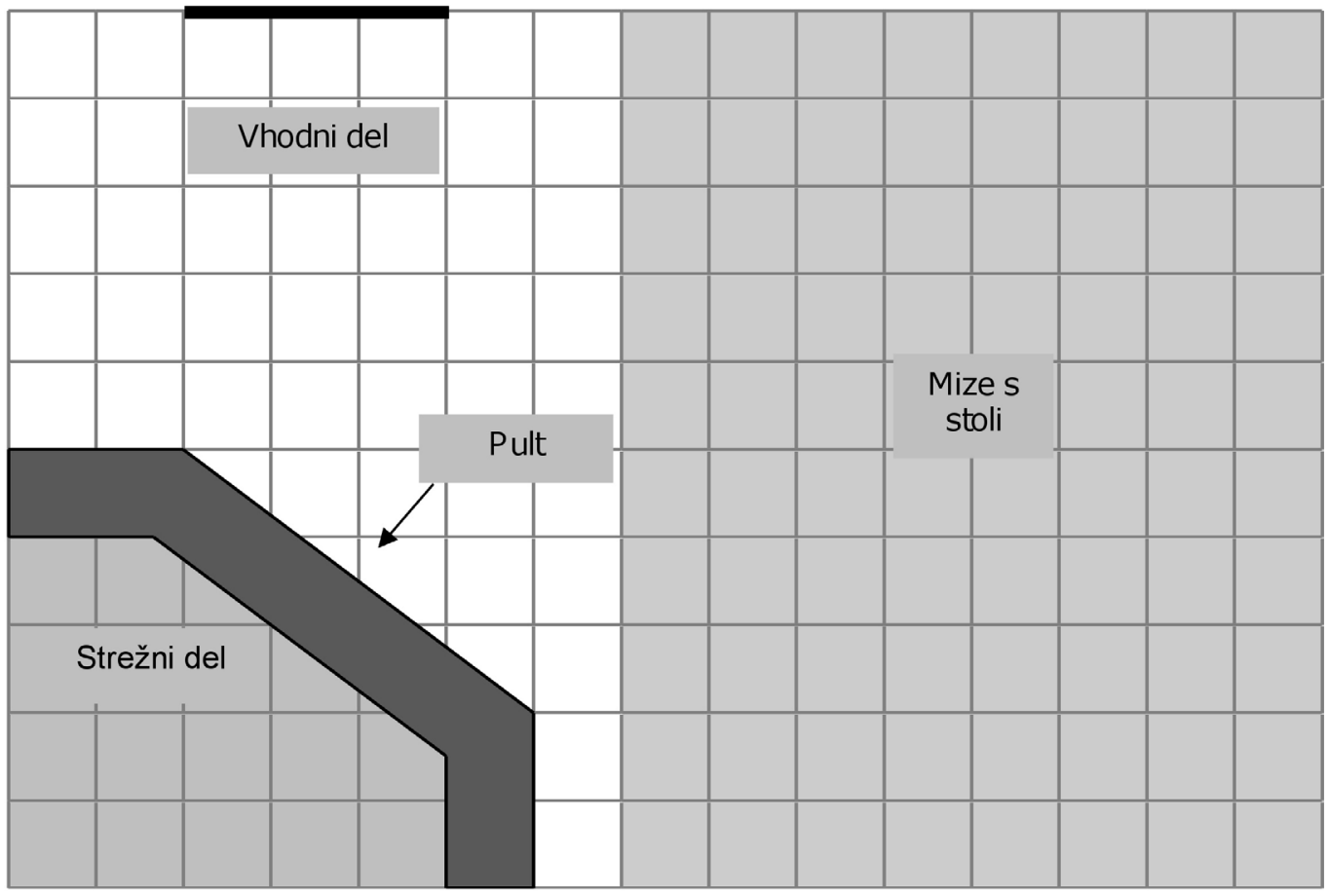

Opomba: Vsak kvadrat mreže predstavlja 0,5 metra $\cdot 0,5$ metra. 
I. vprašanje: PRODAJALNA SLADOLEDA

Maša bi rada dala na zunanji rob pulta novo obrobo. Koliko znaša skupna dolžina obrobe, ki jo potrebuje? Zapiši svoj potek reševanja.

\section{PRODAJALNA SLADOLEDA: TOČKOVANJE 1}

\section{NAMEN VPRAŠANJA:}

Opis: Uporabiti Pitagorov izrek ali natančnih dimenzij za izračun hipotenuze pravokotnega trikotnika in pretvarjanje merskih enot, označenih na tlorisu v merilu Matematično področje: Liki in telesa

Kontekst: Poklicni

Proces: Uporaba

Pravilen odgovor

Koda 2: Od 4,5 do 4,55. [m ali metrov; z enoto ali brez nje]

Delno pravilen odgovor

Koda 1: Odgovori, ki kažejo na delno pravilen postopek (na primer uporaba Pitagorovega izreka ali pravilno branje mreže), vendar vsebujejo napako, na primer napačno uporabo merila ali računsko napako.

- Od 9 do 9,1. [Ne uporabi mreže.]

- $2.5 \mathrm{~m}$ (ali 5 enot). [Uporabi Pitagorov izrek za izraćun hipotenuze, ki meri 5 enot (2,5 metra), ne prišteje pa dveh ravnih stranic.]

Nepravilen odgovor

Koda 0: Drugi odgovori.

Koda 9: Ni odgovora. 
2. vprašanje: PRODAJALNA SLADOLEDA

Maša bo v prodajalni položila tudi nov tlak. Koliko znaša skupna površina (ploščina) prodajalne brez strežnega dela in pulta? Zapiši svoj potek reševanja.

\section{PRODAJALNA SLADOLEDA: TOČKOVANJE 2}

\section{NAMEN VPRAŠANJA:}

Opis: Izračunati ploščine večkotnikov

Matematično področje: Liki in telesa

Kontekst: Poklicni

Proces: Uporaba

Pravilen odgovor

Koda 2: 31,5. [z enoto ali brez nje]

Delno pravilen odgovor

Koda 1: $\quad$ Postopek, ki kaže na pravilno uporabo mreže pri izračunu ploščine, vendar z napačno uporabo merila ali z računsko napako.

- 126. [Iz odgovora je razvidno, da je bila plośčina izračunana pravilno, vendar učenec ni uporabil mreže, da bi dobil pravo vrednost.]

- 7,5 • 5 $(=37,5)-3 \bullet 2,5(=7,5)-1 / 2 \bullet 2 \bullet 1,5(=1,5)=28,5 \mathrm{~m}^{2}$. [Odśteje plošcino trikotnika, namesto da bi jo prištel, ko deli celotno površino na manjše ploščine.]

Nepravilen odgovor

Koda 0: Drugi odgovori.

Koda 9: Ni odgovora. 
3. vprašanje: PRODAJALNA SLADOLEDA

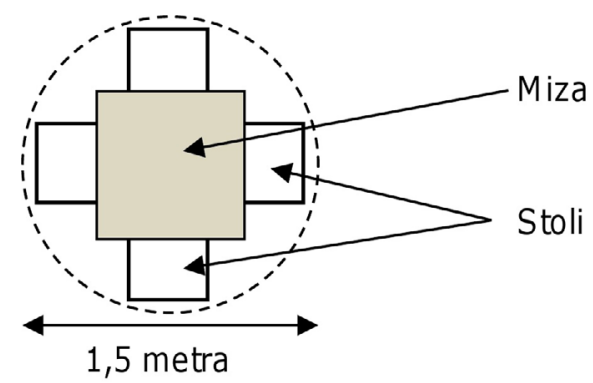

Maša bi rada imela v prodajalni garniture miz s štirimi stoli, kakršna je prikazana na zgornji shemi. Krog predstavlja površino tal, potrebno za vsako garnituro.

Da bodo imeli gostje, ko bodo sedeli pri mizah, dovolj prostora, mora pri postavitvi vsake garniture (ponazorjene s krogom) upoštevati naslednje omejitve:

- Vsaka garnitura mora stati vsaj 0,5 metra od stene.

- Vsaka garnitura mora stati vsaj 0,5 metra od drugih garnitur.

Največ koliko garnitur lahko Maša postavi v osenčeni predel z mizami in s stoli v tlorisu? Število garnitur:

\section{PRODAJALNA SLADOLEDA: TOČKOVANJE 3}

\section{NAMEN VPRAŠANJA:}

Opis: Uporabiti tlorisne mreže in upoštevati določene zahteve za določitev števila krogov, ki jih je mogoče postaviti v večkotnik

Matematično področje: Liki in telesa

Kontekst: Poklicni

Proces: Uporaba

Pravilen odgovor

Koda 1: 4.

Nepravilen odgovor

Koda 0: Drugi odgovori.

Koda 9: Ni odgovora. 
NAFTNI MADEŽ

Tanker je na morju zadel ob čer in v rezervoarju za nafto je nastala luknja. Tanker se je nahajal približno $65 \mathrm{~km}$ od kopnega. Po nekaj dneh se je nafta razlila, kot je prikazano na spodnjem zemljevidu.

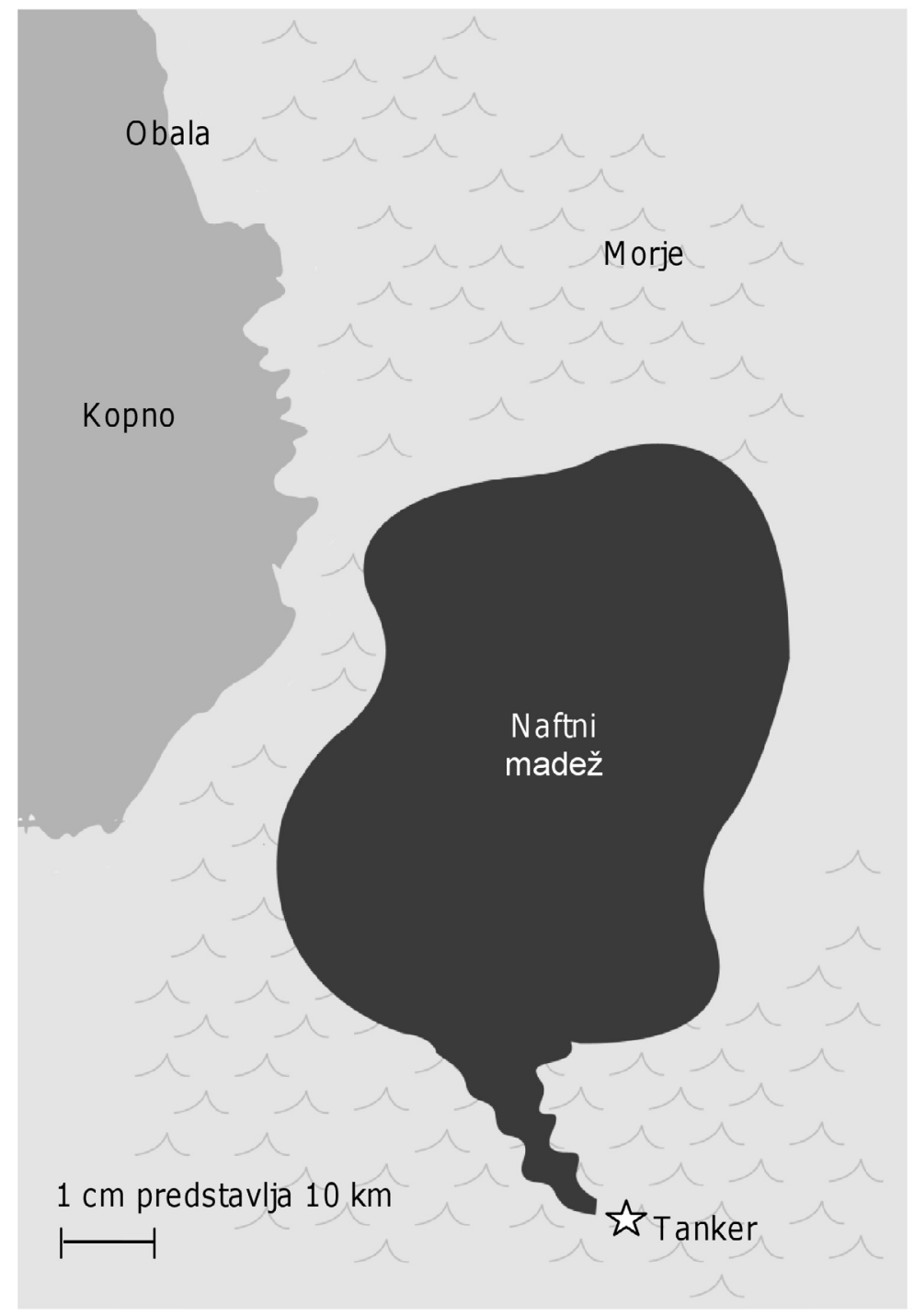


I. vprašanje: NAFTNI MADEŽ

S pomočjo merila na zemljevidu oceni površino (ploščino) naftnega madeža v kvadratnih kilometrih $\left(\mathrm{km}^{2}\right)$.

Odgovor: $\mathrm{km}^{2}$

NAFTNI MADEŽ : TOČKOVANJE 1

NAMEN VPRAŠANJA :

Opis: $S$ pomočjo danega merila oceniti ploščino nepravilne oblike, upodobljeno na zemljevidu

Matematično področje: Liki in telesa

Kontekst: Znanstveni

Proces: Uporaba

Pravilen odgovor

Koda 1: Odgovor v intervalu od 2200 do 3300.

Nepravilen odgovor

Koda 0 : Drugi odgovori.

Koda 9: Ni odgovora. 
PRETOK INFUZIJE

$S$ pomočjo infuzij bolnikom dovajajo tekočine in zdravila.

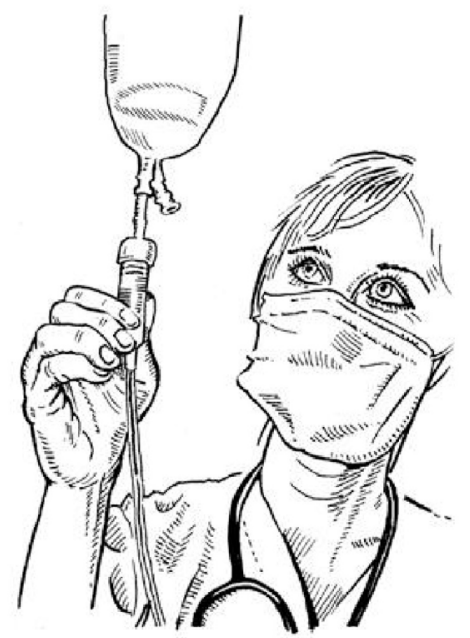

Medicinske sestre morajo pri infuzijah izračunati pretok $P$ v kapljicah na minuto.

Uporabijo formulo $P=\frac{k V}{60 h}$, pri kateri je

$k$ faktor kapljanja, izmerjen v kapljicah na mililiter $(\mathrm{ml})$,

$V$ prostornina infuzije $\mathrm{v} \mathrm{ml}$,

$h$ število ur iztekanja infuzije. 
I. vprašanje: PRETOK INFUZIJE

Medicinska sestra hoče podvojiti čas iztekanja infuzije.

Natančno opiši, kako se $P$ spremeni, če se $h$ podvoji, $k$ in $V$ pa se ne spremenita?

\section{PRETOK INFUZIJE: TOČKOVANJE 1}

\section{NAMEN VPRAŠANJA:}

Opis: Pojasniti učinek podvajanja ene spremenljivke $\mathrm{v}$ formuli na končno vrednost, če vse druge spremenljivke ostanejo enake Matematično področje: Spremenljivke in odnosi Kontekst: Poklicni Proces: Uporaba

Pravilen odgovor

Koda 2: Pojasnilo opiše tako smer kot vrednost učinka.

- Prepolovi se.

- Pol je.

- $P$ bo 50 \% manjša.

- $P$ bo dvakrat manjša.

Delno pravilen odgovor

Koda 1: Samo smer ali vrednost.

- $P$ se zmanjša.

- Spremeni se za $50 \%$.

Nepravilen odgovor

Koda 0: Drugi odgovori.

Koda 9: Ni odgovora. 
3. vprašanje: PRETOK INFUZIJE

Medicinske sestre morajo iz pretoka $P$ izračunati tudi prostornino infuzije $V$.

Bolnik mora 3 ure prejemati infuzijo s pretokom so kapljic na minuto. Pri tej infuziji je faktor kapljanja 25 kapljic na mililiter.

Kolikšna je prostornina infuzije v ml?

Prostornina infuzije: $\mathrm{ml}$

\section{PRETOK INFUZIJE: TOČKOVANJE 3}

\section{NAMEN VPRAŠANJA:}

Opis: Preoblikovati formulo in vstaviti dani vrednosti

Matematično področje: Spremenljivke in odnosi

Kontekst: Poklicni

Proces: Uporaba

\section{Pravilen odgovor}

Koda 1: 360 ali pravilno preoblikovana in vstavljena rešitev

- 360

- $(60 \cdot 3 \cdot 50) \div 25$ [Pravilno preoblikovano in vstavljeno.]

Nepravilen odgovor

Koda 0: Drugi odgovori.

Koda 9: Ni odgovora. 
$\mathrm{MP}_{3}$ PREDVAJALNIKI

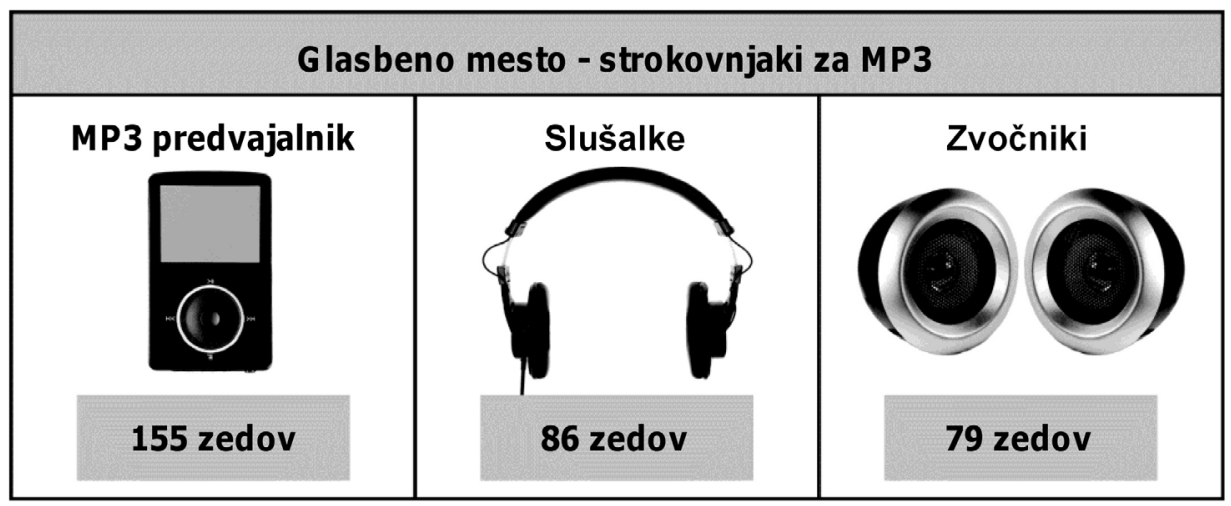

2. vprašanje: MP3 PREDVAJALNIKI

Olga je s pomočjo kalkulatorja seštela cene MP3 predvajalnika, slušalk in zvočnikov.

Dobila je odgovor 248 .

\section{9}

Olgin odgovor je nepravilen. Naredila je eno od naslednjih napak. Katero?
A Eno od cen je seštela dvakrat.
B Eno od treh cen je pozabila prišteti.
C Pri eni od cen je izpustila zadnjo števko.
D Fno od cen ie odštela. namesto da hi in nrištela 
MP3 PREDVAJALNIKI: TOČKOVANJE 2

\section{NAMEN VPRAŠANJA:}

Opis: Prepoznati vzrok za napako pri vnosu števil za seštevanje

Matematično področje: Količine

Kontekst: Osebni

Proces: Uporaba

\section{Pravilen odgovor}

Koda 1: C. Pri eni od cen je izpustila zadnjo številko.

Nepravilen odgovor

Koda 0: Drugi odgovori.

Koda 9: Ni odgovora.

\section{3. vprašanje: $\mathrm{MP}_{3}$ PREDVAJALNIKI}

V Glasbenem mestu je razprodaja. Če kupiš dva ali več izdelkov na razprodaji, ti Glasbeno mesto prizna $20 \%$ popusta na redno prodajno ceno teh izdelkov.

Jaka lahko porabi 200 zedov.

Kaj si lahko kupi na tej razprodaji?

Pri vsaki od naslednjih možnosti obkroži "Da" ali "Ne".

\begin{tabular}{|l|c|}
\hline \multicolumn{1}{|c|}{ Izdelek } & Ali lahko Jaka z 200 zedi kupi te izdelke? \\
\hline MP3 predvajalnik in slušalke. & $\mathrm{Da} / \mathrm{Ne}$ \\
\hline MP3 predvajalnik in zvočnike. & $\mathrm{Da} / \mathrm{Ne}$ \\
\hline $\begin{array}{l}\text { Vse tri izdelke - MP3 predvajalnik, } \\
\text { slušalke in zvočnike. }\end{array}$ & $\mathrm{Da} / \mathrm{Ne}$ \\
\hline
\end{tabular}


MP3 PREDVAJALNIKI: TOČKOVANJE 3

NAMEN VPRAŠANJA:

Opis: Odločiti se, ali bo predvideni denar dovolj za nakup izbranih izdelkov ob upoštevanju popusta

Matematično področje: Količine

Kontekst: Osebni

Proces: Interpretiranje

Pravilen odgovor

Koda 1: Trije pravilni odgovori: Da, Da, Ne, v tem vrstnem redu.

Nepravilen odgovor

Koda 0: Drugi odgovori.

Koda 9: Ni odgovora. 
4. vprašanje: PREDVAJALNIKI MP 3

$\mathrm{V}$ redno prodajno ceno $\mathrm{MP}_{3}$ izdelkov je vključena 37,5 \% trgovska marža. Ceno brez te marže imenujemo veleprodajna cena.

Marža se izračuna kot neki odstotek od veleprodajne cene.

Ali spodnje formule prikazujejo pravilno razmerje med veleprodajno ceno $(v)$ in redno prodajno ceno $(p)$ ?

Pri vsaki od naslednjih formul obkroži "Da" ali "Ne".

\begin{tabular}{|c|c|}
\hline Formula & Ali je formula pravilna? \\
\hline $\mathrm{p}=\mathrm{v}+0,375$ & $\mathrm{Da} / \mathrm{Ne}$ \\
\hline $\mathrm{v}=\mathrm{p}-0,375 \mathrm{p}$ & $\mathrm{Da} / \mathrm{Ne}$ \\
\hline $\mathrm{p}=1,375 \mathrm{v}$ & $\mathrm{Da} / \mathrm{Ne}$ \\
\hline $\mathrm{v}=0,625 \mathrm{p}$ & $\mathrm{Da} / \mathrm{Ne}$ \\
\hline
\end{tabular}

\section{MP3 PREDVAJALNIKI: TOČKOVANJE 4}

\section{NAMEN VPRAŠANJA:}

Opis: Določiti algebraično formulo, ki pravilno opisuje odnos med dvema spremenljivkama, kjer ena vključuje fiksen odstotek trgovske marže

Matematično področje: Spremenljivke in odnosi

Kontekst: Poklicni

Proces: Formuliranje

Pravilen odgovor

Koda 1: Štirje pravilni odgovori: $\mathrm{Ne}, \mathrm{Ne}, \mathrm{Da}, \mathrm{Ne}, \mathrm{v}$ tem vrstnem redu.

Nepravilen odgovor

Koda 0: Drugi odgovori.

Koda 9: Ni odgovora. 


\section{LESTVICE}

Januarja sta izšla nova CD-ja skupin Pravi rokerji in Poskočni kenguruji. Februarja pa sta izšla še nova CD-ja skupin Nikogaršnja ljubica in Metalci. Spodnji graf prikazuje prodajo CD-jev vseh skupin od januarja do junija.

Mesečna prodaja CD-jev

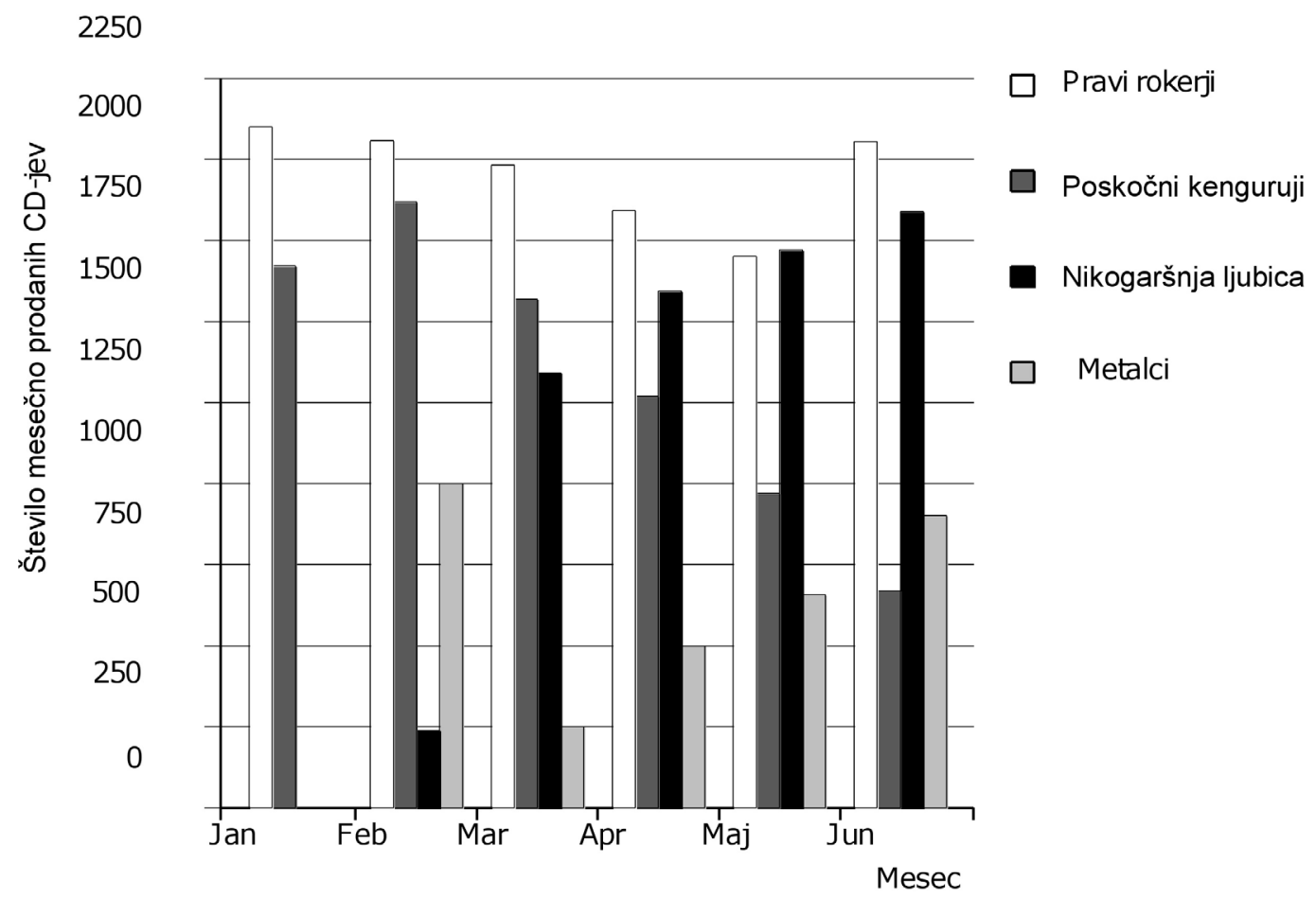


I. vprašanje: LESTVICE

Koliko CD-jev je skupina Metalci prodala aprila?
A 250.
B 500 .
C 1000 .
D 1270.

\section{LESTVICE: TOČKOVANJE 1}

\section{NAMEN VPRAŠANJA:}

Opis: Branje stolpčnega diagrama

Matematično področje: Verjetnost in delo s podatki

Kontekst: Družbeni

Proces: Interpretiranje

Pravilen odgovor

Koda 1: B 500.

Nepravilen odgovor

Koda 0: Drugi odgovori.

Koda 9: Ni odgovora. 
2. vprašanje: LESTVICE

Katerega meseca je skupina Nikogaršnja ljubica prvič prodala več CD-jev kot skupina Poskočnikenguruji?
A Nobenega meseca.
B Marca.
C Aprila.
D Maja.

\section{LESTVICE: TOČKOVANJE 2}

\section{NAMEN VPRAŠANJA:}

Opis: Prebrati stolpčni diagram ter primerjati višino dveh stolpičev

Matematično področje: Verjetnost in delo s podatki

Kontekst: Družbeni

Proces: Interpretiranje

Pravilen odgovor

Koda 1: C. Aprila

Nepravilen odgovor

Koda 0: Drugi odgovori.

Koda 9: Ni odgovora.

\section{5. vprašanje: LESTVICE}

Menedžer Poskočnih kengurujev je v skrbeh, ker se je število njihovih prodanih CD-jev od februarja do junija zmanjšalo.

Kolikšen je ocenjen obseg njihove prodaje za julij, če se bo upadanje prodaje nadaljevalo?
A $70 \mathrm{CD}$-jev.
B $370 \mathrm{CD}$-jev.
C $670 \mathrm{CD}$-jev.
D $1340 \mathrm{CD}$-jev. 
LSTVICE: TOČKOVANJE 5

NAMEN VPRAŠANJA:

Opis: Interpretirati stolpčni diagram in oceniti število prodanih CD-jev v prihodnosti ob predvidevanju, da se bo linearni trend nadaljeval

Matematično področje: Verjetnost in delo s podatki

Kontekst: Družbeni

Proces: Interpretiranje

Pravilen odgovor

Koda 1: B. 370 CD-jev

Nepravilen odgovor

Koda 0: Drugi odgovori.

Koda 9: Ni odgovora. 


\section{PINGVINI}

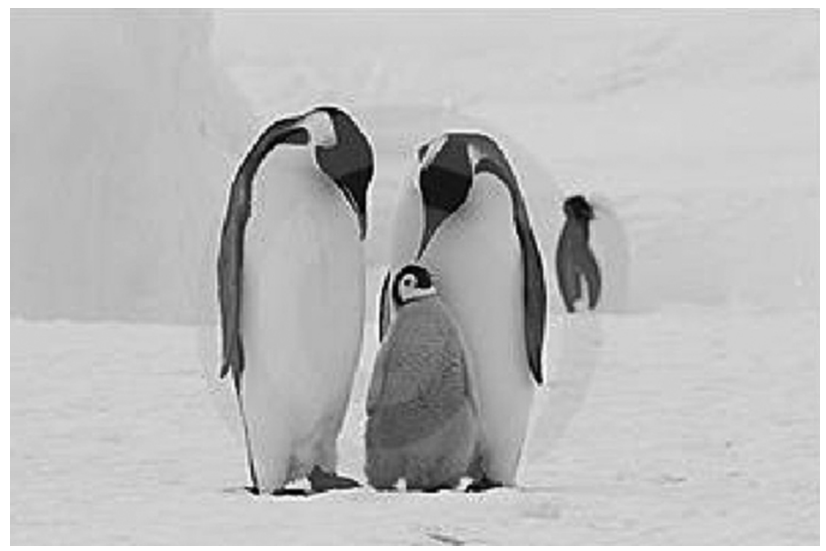

Fotograf živalskega sveta Jean Baptiste je odšel na enoletno odpravo ter posnel številne fotografije pingvinov in njihovih mladičev.

Zanimalo ga je predvsem povečevanje velikosti kolonij različnih pingvinov.

\section{I. vprašanje: PINGVINI}

Pingvinji par po navadi izleže dve jajci na leto. Običajno preživi le mladič, ki se izvali iz večjega od obeh jajc.

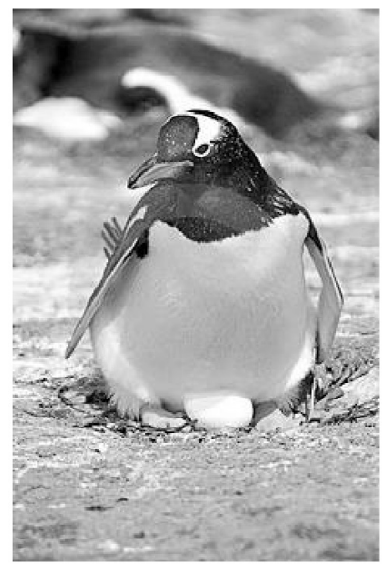


Pri skalnih pingvinih tehta prvo jajce okoli 78 g, drugo pa okoli I Io g.

Za približno koliko odstotkov je drugo jajce težje od prvega?
A $29 \%$.
B $32 \%$.
C $4 \mathrm{I} \%$.
D $7 \mathrm{I} \%$.

\section{PINGVINI: TOČKOVANJE 1}

\section{NAMEN VPRAŠANJA:}

Opis: Računanje z odstotki v okviru realnega konteksta

Matematično področje: Količine

Kontekst: Znanstveni

Proces: Uporaba

\section{Pravilen odgovor}

Koda 1: C. $41 \%$

Nepravilen odgovor

Koda 0: Drugi odgovori.

Koda 9: Ni odgovora.

\section{2. vprašanje: PINGVINI}

Jeana zanima, kako se bo velikost določene kolonije pingvinov spreminjala v naslednjih letih. Da bi lahko to ugotovil, si zapiše naslednje domneve:

- Na začetku leta je v koloniji 10000 pingvinov (5 000 parov).

- Vsak par pingvinov vzgoji vsako pomlad po enega mladiča.

- Do konca leta bo poginilo $20 \%$ vseh pingvinov (odraslih in mladičev).

Koliko pingvinov (odraslih in mladičev) bo ob koncu prvega leta v tej koloniji?

Število pingvinov: 
PINGVINI: TOČKOVANJE 2

NAMEN VPRAŠANJA:

Opis: Razumeti situacijo iz realnega življenja in na podlagi spremembe (povečanje ali zmanjšanje) v odstotkih izračunati konkretno število

Matematično področje: Količine

Kontekst: Znanstveni

Proces: Formuliranje

Pravilen odgovor

Koda 1: 12000

Nepravilen odgovor

Koda 0: Drugi odgovori.

Koda 9: Ni odgovora.

\section{3. vprašanje: PINGVINI}

Jean domneva, da se bo kolonija še naprej povečevala na naslednji način:

- Na začetku vsakega leta je v koloniji enako število samcev in samic, ki tvorijo pare.

- Vsak par pingvinov vsako pomlad vzgoji po enega mladiča.

- Do konca vsakega leta bo poginilo $20 \%$ vseh pingvinov (odraslih in mladičev).

- Eno leto stari pingvini bodo prav tako vzgojili mladiče.

Katera od naslednjih formul na podlagi zgornjih domnev pravilno prikaže skupno število pingvinov $(P)$ po sedmih letih?
A $P=10000 \cdot(1,5 \cdot 0,2)^{7}$
B $P=10000 \cdot(1,5 \cdot 0,8)^{7}$
C $P=10000 \cdot(1,2 \cdot 0,2)^{7}$
D $P=10000 \cdot(1,2 \cdot 0,8)^{7}$ 
PINGVINI: TOČKOVANJE 3

\section{NAMEN VPRAŠANJA:}

Opis: Razumeti dano situacijo in izbrati primeren matematični model

Matematično področje: Spremenljivke in odnosi

Kontekst: Znanstveni

Proces: Formuliranje

\section{Pravilen odgovor}

Koda 1: $\quad$ B. $P=10000 \cdot(1.5 \times 0.8)^{7}$

Nepravilen odgovor

Koda 0: Drugi odgovori.

Koda 9: Ni odgovora.

\section{4. vprašanje: PINGVINI}

Po vrnitvi z odprave je Jean Baptiste na internetu preveril, koliko mladičev v povprečju vzgoji pingvinji par.

Našel je spodnji stolpčni graf za tri vrste pingvinov: oslovske, skalne in magellanove pingvine.

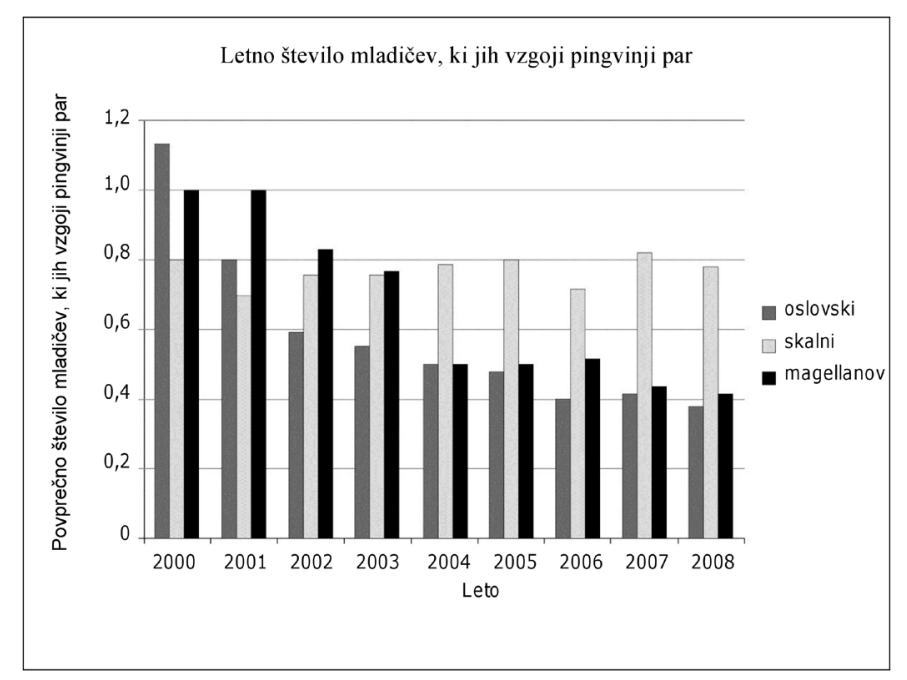


Ali naslednje trditve o teh treh vrstah pingvinov glede na zgornji graf držijo ali ne držijo?

Pri vsaki trditvi obkroži "Drži” ali "Ne drži”.

\begin{tabular}{|l|c|}
\hline \multicolumn{1}{|c|}{ Trditev } & $\begin{array}{c}\text { Ali ta trditev drži ali ne } \\
\text { drži } ?\end{array}$ \\
\hline $\begin{array}{l}\text { Leta } 2000 \text { je bilo povprečno število mladičev, ki jih je } \\
\text { vzgojil pingvinji par, večje od 0,6. }\end{array}$ & Drži / Ne drži \\
\hline $\begin{array}{l}\text { Leta 2006 je v povprečju manj kot } 80 \% \text { pingvinjih } \\
\text { parov vzgojilo mladiča. }\end{array}$ & Drži / Ne drži \\
\hline $\begin{array}{l}\text { Približno do leta 2015 bodo te tri vrste pingvinov } \\
\text { izumrle. }\end{array}$ & Drži / Ne drži \\
\hline $\begin{array}{l}\text { Povprečno število mladičev, ki jih vzgoji par } \\
\text { magellanovih pingvinov, se je med letoma } 2001 \text { in } \\
\text { 2004 zmanjšalo. }\end{array}$ & Drži / Ne drži \\
\hline
\end{tabular}

\section{PINGVINI: TOČKOVANJE 4}

\section{NAMEN VPRAŠANJA:}

Opis: Analizirati različne trditve ob upoštevanju stolpčnega diagrama

Matematično področje: Verjetnost in delo s podatki

Kontekst: Znanstveni

Proces: Interpretiranje

\section{Pravilen odgovor}

Koda 1: Štirje pravilni odgovori: Drži, Drži, Ne drži, Drži, v tem vrstnem redu.

Nepravilen odgovor

Koda 0: Drugi odgovori.

Koda 9: Ni odgovora. 


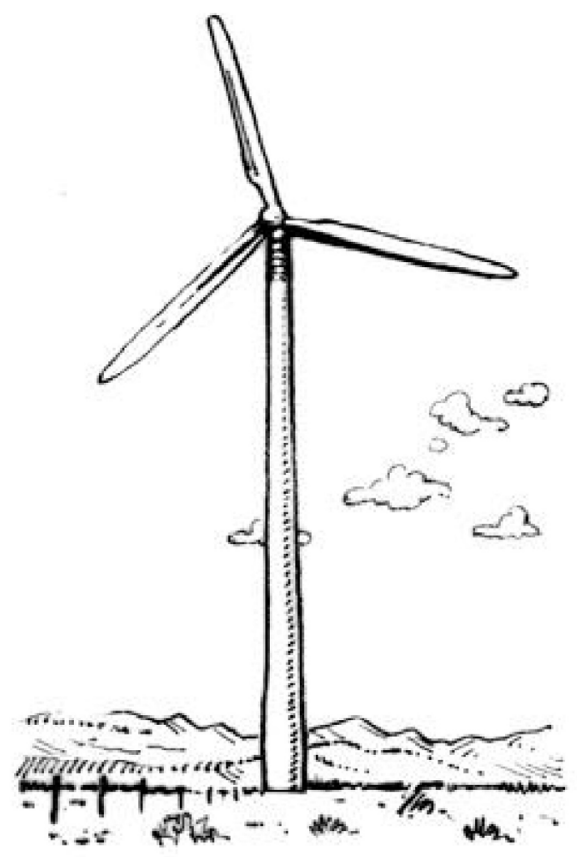

V Zedgradu razmišljajo o postavitvi vetrnih turbin za pridobivanje električne energije.

Zedgrajski mestni svet je zbral podatke o naslednjem modelu.

Model:

E-82

Višina stolpa:

138 metrov

Število lopatic rotorja: 3

Dolžina lopatic rotorja: 40 metrov

Največja hitrost

20 vrtljajev na minuto

vrtenja:

Cena gradnje: $\quad 3200000$ zedov

Prihodek:

0,10 zeda na proizvedeno $\mathrm{kWh}$

Stroški vzdrževanja: $\quad 0,01$ zeda na proizvedeno $\mathrm{kWh}$

Učinkovitost:

Deluje $97 \%$ leta

Opomba: kilovatna ura $(\mathrm{kWh})$ je enota za električno energijo. 
I. vprašanje: VETRNA ENERGIJA

Ugotovi, ali lahko na podlagi zbranih podatkov izpeljemo naslednje trditve o vetrni turbini E-82. Pri vsaki trditvi obkroži "Da” ali "Ne".

\begin{tabular}{|l|c|}
\hline \multicolumn{1}{|c|}{ Trditev } & $\begin{array}{c}\text { Ali to trditev lahko izpeljemo na podlagi } \\
\text { zbranih podatkov? }\end{array}$ \\
\hline $\begin{array}{l}\text { Gradnja treh vetrnih turbin bo skupaj } \\
\text { stala več kot } 8000000 \text { zedov. }\end{array}$ & $\mathrm{Da} / \mathrm{Ne}$ \\
\hline $\begin{array}{l}\text { Stroški vzdrževanja vetrne turbine } \\
\text { znašajo približno 5\% njenega prihodka. }\end{array}$ & $\mathrm{Da} / \mathrm{Ne}$ \\
\hline $\begin{array}{l}\text { Stroški vzdrževanja vetrne turbine so } \\
\text { odvisni od količine proizvedenih kWh. }\end{array}$ & $\mathrm{Da} / \mathrm{Ne}$ \\
\hline $\begin{array}{l}\text { Vetrna turbina ne deluje natanko } 97 \mathrm{dni} \\
\text { na leto. }\end{array}$ & $\mathrm{Da} / \mathrm{Ne}$ \\
\hline
\end{tabular}

\section{VETRNA ENERGIJA: TOČKOVANJE 1}

\section{NAMEN VPRAŠANJA:}

Opis: Analizirati različne informacije o danem scenariju

Matematično področje: Spremenljivke in odnosi

Kontekst: Znanstveni

Proces: Interpretiranje

\section{Pravilen odgovor}

Koda 1: Štirje pravilni odgovori: Da, Ne, Da, v tem vrstnem redu

Nepravilen odgovor

Koda 0: Drugi odgovori.

Koda 9: Ni odgovora. 
2. vprašanje: VETRNA ENERGIJA

V Zedgradu želijo oceniti stroške in dobiček, ki bi jih ustvarila gradnja vetrne turbine.

Zedgrajski župan predlaga naslednjo formulo za ocenitev denarnega dobička $D$ (v zedih) v obdobju več let $L$, če bi zgradili model E-82.

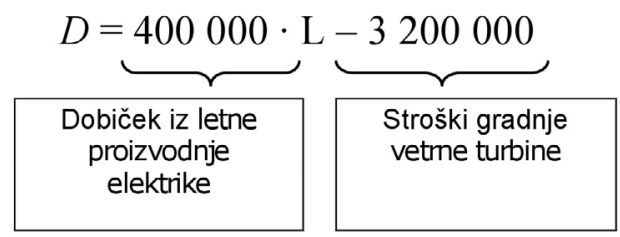

Kolikšno je glede na županovo formulo najmanjše število let delovanja vetrne turbine, da bi pokrili stroške njene gradnje?
A 6 let.
B 8 let.
C ro let.
D i2 let.

\section{VETRNA ENERGIJA: TOČKOVANJE 2}

\section{NAMEN VPRAŠANJA:}

Opis: Razumeti in razrešiti dano formulo v določenem kontekstu

Matematično področje: Spremenljivke in odnosi

Kontekst: Znanstveni

Proces: Uporaba

Pravilen odgovor

Koda 1: B.8 let

Nepravilen odgovor

Koda 0: Drugi odgovori.

Koda 9: Ni odgovora. 
3. vprašanje: VETRNA ENERGIJA

V Zedgradu so se odločili postaviti nekaj vetrnih turbin E-82 na kvadratnem polju

$($ dolžina $=$ širina $=500 \mathrm{~m})$.

Po predpisih gradnje mora biti najmanjša razdalja med stolpi vetrnih turbin tega modela enaka petkratni dolžini lopatice rotorja.

Župan je predlagal, kako bi razporedili vetrne

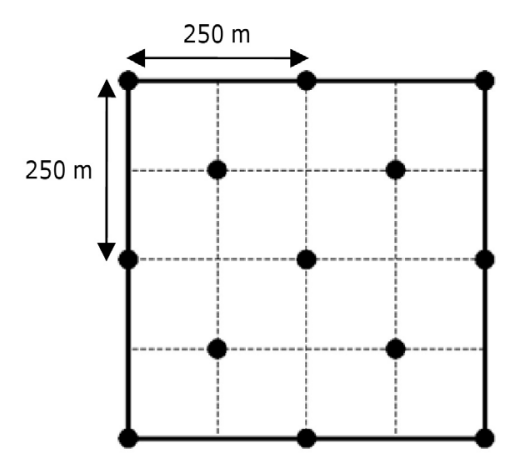

- = stolp vetrne turbine Opomba: Shema ni v merilu.

turbine po polju. Njegov predlog je prikazan $\mathrm{v}$ shemi na desni.

Pojasni, zakaj županov predlog ni v skladu s predpisi gradnje. Svoje pojasnilo podpri z izračunom. 
NAMEN VPRAŠANJA:

Opis: Uporabiti Pitagorov izrek v stvarnem kontekstu

Matematično področje: Liki in telesa

Kontekst: Znanstveni

Proces: Uporaba

Pravilen odgovor

Koda 1: Odgovor, ki pravilno in razumljivo matematično prikaže, da najmanjša zahtevana razdalja, enaka dolžini petih lopatic rotorja (torej $200 \mathrm{~m}$ ), ni upoštevana med vsemi vetrnimi turbinami. Skica bi bila zaželena, ni pa obvezna, prav tako ni obvezno podati stavka z odgovorom.

- Vetrnih turbin ne morejo postaviti tako, ker je razdalja med nekaterimi sa mo $\sqrt{125^{2}+125^{2}} \approx 177 \mathrm{~m}$.

Nepravilen odgovor

Koda 0: Drugi odgovori.

Koda 9: Ni odgovora.

4. vprašanje: VETRNA ENERGIJA

Kolikšna je največja hitrost, s katero se premikajo konci lopatic rotorja vetrne turbine? Opiši svoj postopek reševanja in rezultat podaj v kilometrih na uro $(\mathrm{km} / \mathrm{h})$. Pomagaj si s podatki o modelu E-82.

Največja hitrost: $\mathrm{km} / \mathrm{h}$ 
VETRNA ENERGIJA: TOČKOVANJE 4

\section{NAMEN VPRAŠANJA:}

Opis: Uporabiti modeliranje v več korakih pri reševanju problema o gibanju Matematično področje: Spremenljivke in odnosi

Kontekst: Znanstveni

Proces: Uporaba

Pravilen odgovor

Koda 2: Pravilen rezultat je pridobljen s pravilnim, popolnim in razumljivim procesom reševanja. Rezultat mora biti naveden $\mathrm{v} \mathrm{km} / \mathrm{h}$. Skica ni obvezna, prav tako ni obvezno podati stavka $\mathrm{z}$ odgovorom.

- Največja hitrost vrtenja je 20 vrtljajev na minuto; razdalja na vrtljaj je 2 $\cdot \pi \cdot 40 \mathrm{~m} \approx 250 \mathrm{~m}$; torej $20.250 \mathrm{~m} / \mathrm{min} \approx 5000 \mathrm{~m} / \mathrm{min} \approx 83 \mathrm{~m} / \mathrm{s} \approx$ $300 \mathrm{~km} / \mathrm{h}$.

Delno pravilen odgovor

Koda 1: Pravilen rezultat je pridobljen s pravilnim, popolnim in razumljivim procesom reševanja. Vendar pa rezultat ni podan $\mathrm{v} \mathrm{km} / \mathrm{h}$. Tudi tu skica ni obvezna, prav tako ni obvezno podati stavka z odgovorom.

- Največja hitrost vrtenja je 20 vrtljajev na minuto; razdalja na vrtljaj je 2 . $\pi .40 \mathrm{~m} \approx 250 \mathrm{~m}$; torej $20.250 \mathrm{~m} / \mathrm{min} \approx 5000 \mathrm{~m} / \mathrm{min} \approx 83 \mathrm{~m} / \mathrm{s}$.

Nepravilen odgovor

Koda 0: Drugi odgovori.

Koda 9: Ni odgovora. 


\section{TOVORNE LADJE NA JADRA}

Petindevetdeset odstotkov svetovne trgovine poteka po morskih poteh v približno 50000 tankerjih, ladjah za prevoz razsutega tovora in kontejnerskih ladjah. Večino teh ladij poganja dizelsko gorivo.

Inženirji načrtujejo sistem, ki bo za dodaten

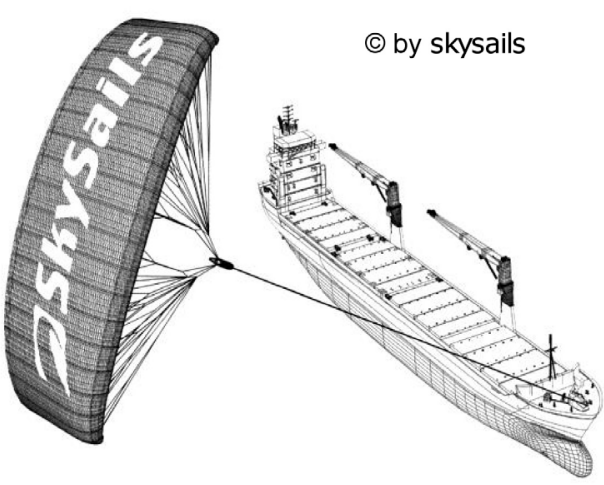
pogon izkoriščal moč vetra. Predlagajo, da bi na tovorne ladje pritrdili jadralno padalo in tako z izkoriščanjem moči vetra zmanjšali porabo dizla ter škodljive vplive goriva na okolje.

\section{I. vprašanje: TOVORNE LADJE NA JADRA}

Jadralna padala imajo to prednost, da lahko letijo na višini $150 \mathrm{~m}$. Na tej višini je hitrost vetra za približno $25 \%$ večja kot spodaj na ladijski palubi.

Kolikšna je približna hitrost vetra, ki piha v jadralno padalo, če je hitrost vetra, izmerjena na palubi kontejnerske ladje, $24 \mathrm{~km} / \mathrm{h}$ ?
A $6 \mathrm{~km} / \mathrm{h}$.
B $\quad$ I $8 \mathrm{~km} / \mathrm{h}$.
C $25 \mathrm{~km} / \mathrm{h}$.
D $30 \mathrm{~km} / \mathrm{h}$.
E $49 \mathrm{~km} / \mathrm{h}$.

\section{TOVORNE LADJE NA JADRA: TOČKOVANJE 1}

\section{NAMEN VPRAŠANJA:}

Opis: Uporabiti izračun odstotkov v dani življenjski situaciji

Matematično področje: Količine 
Kontekst: Znanstveni

Proces: Uporaba

Pravilen odgovor

Koda 1: D $30 \mathrm{~km} / \mathrm{h}$

Nepravilen odgovor

Koda 0: Drugi odgovori.

Koda 9: Ni odgovora.

\section{2. vprašanje: TOVORNE LADJE NA JADRA}

Za izračun vzgona $F$ jadralnega padala, ki vleče tovorno ladjo, lahko uporabimo naslednjo formulo:

\begin{tabular}{|l|}
\hline$F:$ količnik vzgona jadralnega padala \\
$F=\frac{k \cdot g \cdot P}{2} v^{2}$ \\
$P:$ površina (ploščina) jadralnega padala \\
$v:$ hitrost vetra v jadralnem padalu
\end{tabular}

Kako se spremeni vzgon $(F)$, če se hitrost vetra $(v)$ v jadralnem padalu dvakrat poveča?

$F$ se dvakrat poveča.

$F$ se trikrat poveča.

$F$ se štirikrat poveča.

$F$ se petkrat poveča. 
TOVORNE LADJE NA JADRA: TOČKOVANJE 2

\section{NAMEN VPRAŠANJA:}

Opis: Uporabiti matematične tehnike in znanje pri analiziranju dane formule

Matematično področje: Spremenljivke in odnosi

Kontekst: Znanstveni

Proces: Interpretiranje

Pravilen odgovor

Koda 1: C F se štirikrat poveča.

Nepravilen odgovor

Koda 0: Drugi odgovori.

Koda 9: Ni odgovora.

\section{3. vprašanje: TOVORNE LADJE NA JADRA}

Kolikšna mora biti približna dolžina

vrvi jadralnega padala, da bo lahko

vleklo tovorno ladjo pod kotom $45^{\circ}$,

njegova navpična višina pa bo 150

$\mathrm{m}$, kot je prikazano v shemi na

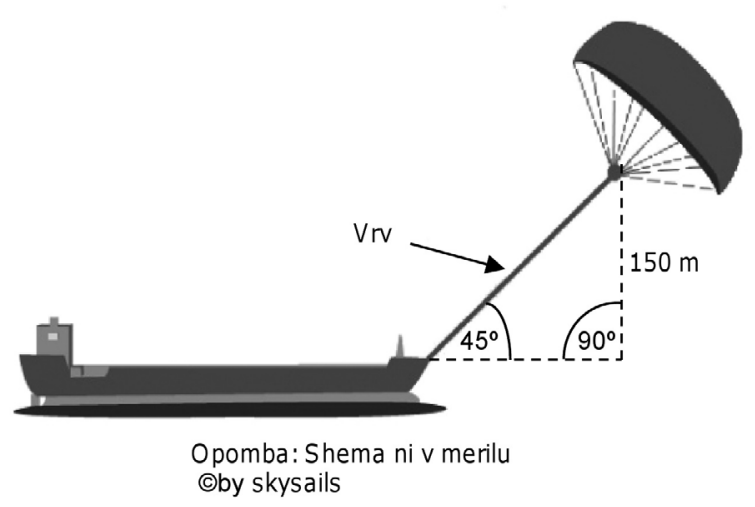
A $\quad 173 \mathrm{~m}$.
B $212 \mathrm{~m}$.
C $285 \mathrm{~m}$.
D $300 \mathrm{~m}$. 
TOVORNE LADJE NA JADRA: TOČKOVANJE 3

\section{NAMEN VPRAŠANJA:}

Opis: Uporabiti Pitagorov izrek v okviru resničnega, geometričnega konteksta Matematično področje: Liki in telesa

Kontekst: Znanstveni

Proces: Uporaba

Pravilen odgovor

Koda1: B $212 \mathrm{~m}$

Nepravilen odgovor

Koda 0: Drugi odgovori.

Koda 9: Ni odgovora.

\section{4. vprašanje: TOVORNE LADJE NA JADRA}

Zaradi visoke cene dizelskega goriva ( 0,42 zeda za liter) nameravajo lastniki tovorno ladjo Novi val opremiti z jadralnim padalom.

Ocenjujejo, da bi takšno jadralno padalo lahko zmanjšalo celotno porabo dizla za približno $20 \%$.

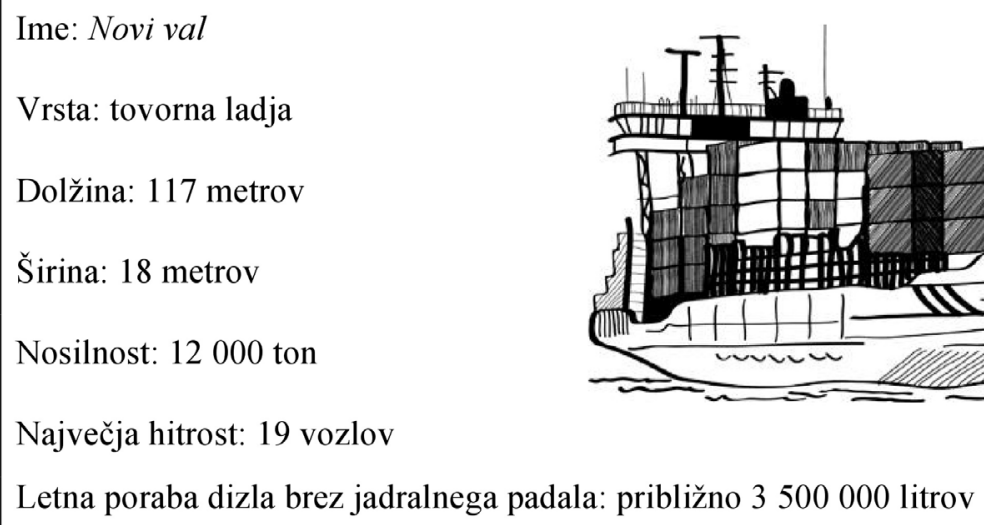

Letna poraba dizla brez jadralnega padala: približno 3500000 litrov 
Cena za to, da bodo Novi val opremili z jadralnim padalom, je 2500000 zedov.

Čez koliko let bo prihranek pri dizlu pokril ceno jadralnega padala? Svoj odgovor podpri z izračunom.

Število let:

\section{TOVORNE LADJE: TOČKOVANJE 4}

NAMEN VPRAŠANJA:

Opis: Uporabiti matematični model v več korakih in rešiti kompleksno situacijo iz resničnega življenja

Matematično področje: Spremenljivke in odnosi

Kontekst: Znanstveni

Proces: Formuliranje

Pravilen odgovor

Koda 1: Odgovori od 8 do 9 let s pravilnimi (matematičnimi) izračuni.

- Letna poraba dizla brez jadralnega padala: 3,5 milijona litrov za ceno 0,42 zeda/liter. Če z jadralnim padalom prihranimo $20 \%$ energije, prihranimo 1470000 zedov $\cdot 0,2=294000$ zedov na leto. Torej $2500000 \div 294000 \approx 8,5:$ nakup jadralnega padala se (finančno) povrne po približno 8 do 9 letih.

Nepravilen odgovor

Koda 0: Drugi odgovori.

Koda 9: Ni odgovora. 


\section{OMAKA}

\section{2. vprašanje: OMAKA}

Pripravljaš si domači solatni preliv.

To je recept za pripravo roo mililitrov $(\mathrm{ml})$ preliva.

\begin{tabular}{|c|c|}
\hline Olje: & $60 \mathrm{ml}$ \\
\hline Kis: & $30 \mathrm{ml}$ \\
\hline Sojina omaka: & $10 \mathrm{ml}$ \\
\hline
\end{tabular}

Koliko mililitrov (ml) olja potrebuješ za pripravo $150 \mathrm{ml}$ preliva?

Odgovor: $\mathrm{ml}$

\section{OMAKA: TOČKOVANJE 2}

\section{NAMEN VPRAŠANJA:}

Opis: Uporabiti koncept razmerij v situaciji iz vsakdanjega življenja za izračun količine ene sestavine $\mathrm{v}$ receptu

Matematično področje: Količine

Kontekst: Osebni

Proces: Formuliranje

\section{Pravilen odgovor}

Koda 1: 90

Nepravilen odgovor

Koda 0: Drugi odgovori.

- 1,5 krat več [Treba je izračunati zabtevano količino.]

Koda 9: Ni odgovora. 


\section{FERRISOVO KOLO}

V Londonu stoji ob reki Temzi veliko razgledno kolo, ki mu pravijo Ferrisovo kolo. Spodaj vidiš fotografijo in shemo:
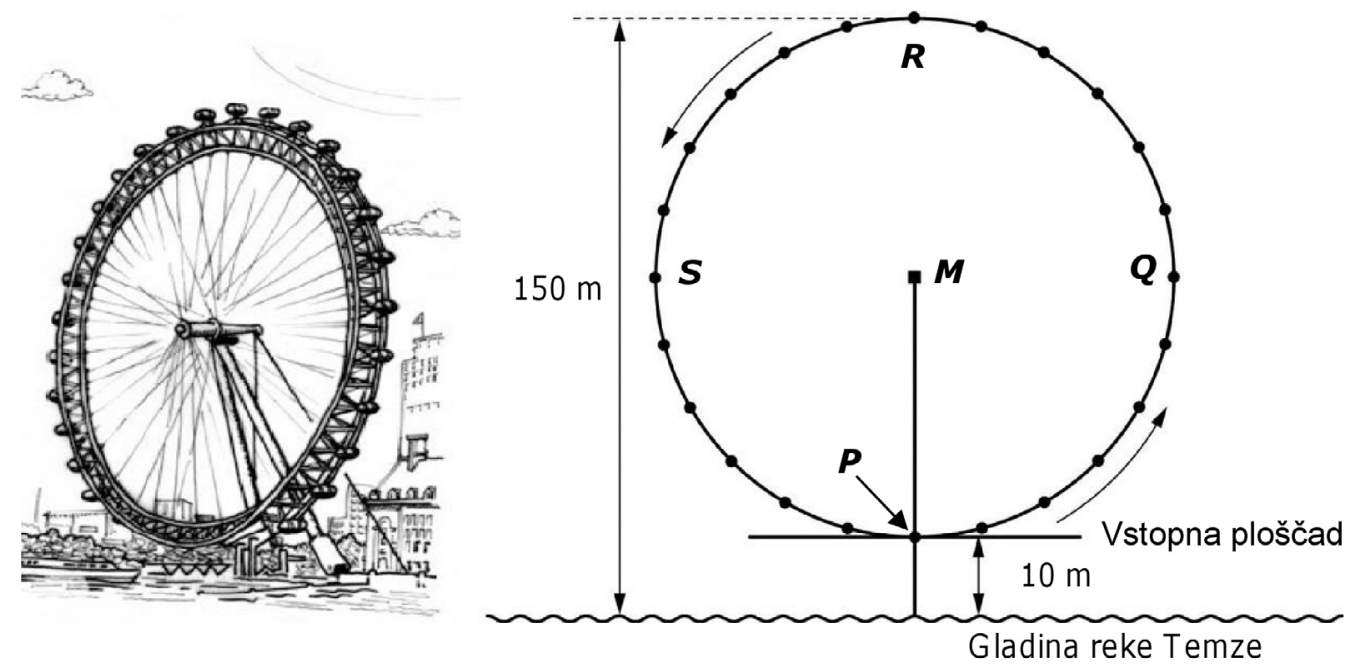

Zunanji premer razglednega kolesa je I40 metrov, njegova najvišja točka pa je I50 metrov nad gladino reke Temze, na rečnem bregu. Vrti se v smeri, ki jo kažeta puščici.

I. vprašanje: FERRISOVO KOLO

Črka $M \mathrm{v}$ shemi označuje središče kolesa.

Koliko metrov (m) nad rečno gladino je točka $M$ ?

Odgovor: $\mathrm{m}$

\section{FERRISOVO KOLO: TOČKOVANJE 1}

\section{NAMEN VPRAŠANJA:}

Opis: Izračunati dolžino na podlagi podatkov iz dvodimenzionalne risbe Matematično področje: Liki in telesa 
Kontekst: Družbeni

Proces: Uporaba

Pravilen odgovor

Koda 1: 80

Nepravilen odgovor

Koda 0: Drugi odgovori.

Koda 9: Ni odgovora.

\section{2. vprašanje: FERRISOVO KOLO}

Razgledno kolo se vrti s konstantno hitrostjo. En poln obrat naredi v točno 40 minutah. Janez začne vožnjo z razglednim kolesom na vstopni točki $P$.

Kje bo Janez čez pol ure?
A Na točki $R$.
B Med točkama $R$ in $S$.
C Na točki $S$.
D Med točkama $S$ in $P$.

FERRISOVO KOLO: TOČKOVANJE 2

NAMEN VPRAŠANJA:

Opis: Oceniti lokacijo objekta ob upoštevanju vrtenja in navedenega potrebnega časa

Matematično področje: Liki in telesa

Kontekst: Družbeni

Proces: Uporaba

Pravilen odgovor

Koda 1: C. Na točki $R$

Nepravilen odgovor

Koda 0: Drugi odgovori.

Koda 9: Ni odgovora. 
ZLAGANJE KOCK

Na spodnji sliki je sklad iz sedmih enakih kock s stranicami, označenimi od 1 do 6.

Pogled od

$\sqrt{ }$

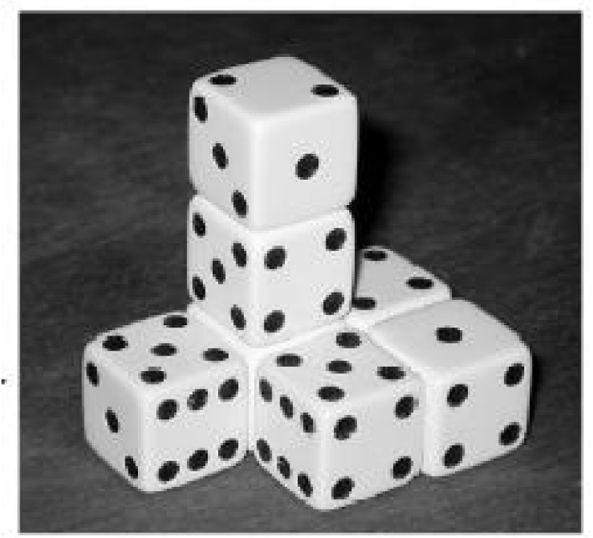

Če sklad pogledamo od zgoraj, vidimo samo 5 kock. 
I. vprašanje: ZLAGANJE KOCK

Koliko pik lahko vidimo, če ta sklad pogledamo od zgoraj?

Število pik, ki jih vidimo:

\section{ZLAGANJE KOCK: TOČKOVANJE 1}

\section{NAMEN VPRAŠANJA:}

Opis: Interpretirati določeno perspektivo na fotografiji tridimenzionalnega sklada

Matematično področje: Liki in telesa

Kontekst: Osebni

Proces: Interpretiranje

Pravilen odgovor

Koda 2: 17

Delno pravilen odgovor

Koda 1: 16

Nepravilen odgovor

Koda 0: Drugi odgovori.

Koda 9: Ni odgovora. 
VZPON NA GORO FUDŽI

Gora Fudži je znan ugasli vulkan na Japonskem.

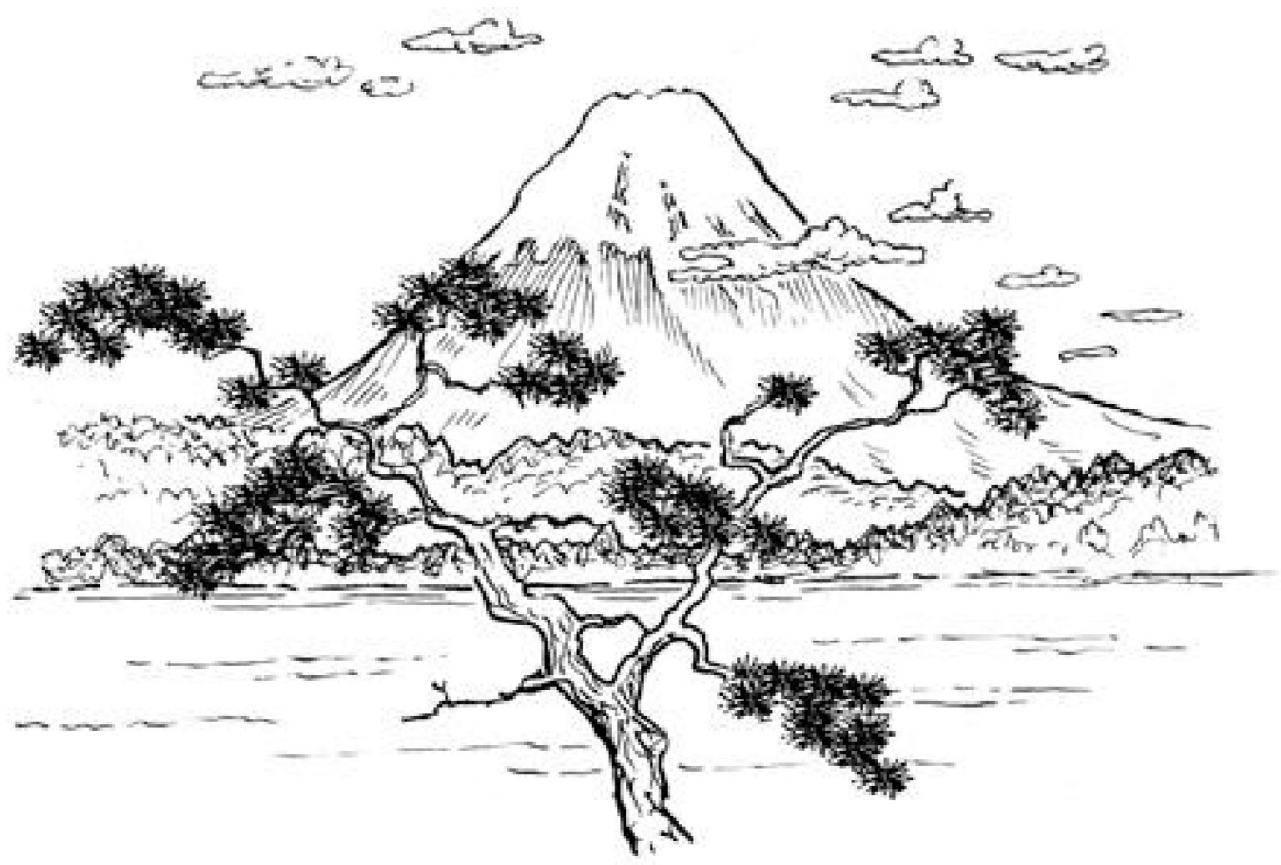

I. vprašanje: VZPON NA GORO FUDŽI

Gora Fudži je za obiskovalce vsako leto dostopna samo od 1. julija do 27. avgusta. V tem času se nanjo povzpne približno 200000 ljudi.

Koliko ljudi se v povprečju vsak dan povzpne na goro Fudži?
A 340.
B 710.
C 3400 .
D 7100.
E 7400 . 
VZPON NA GORO FUDŽI: TOČKOVANJE 1

\section{NAMEN VPRAŠANJA:}

Opis: Prepoznati povprečni dnevni delež na podlagi skupnega števila in določenega časa

Matematično področje: Količine

Kontekst: Družbeni

Proces: Formuliranje

Pravilen odgovor

Koda 1: C 3400.

Nepravilen odgovor

Koda 0: Drugi odgovori.

Koda 9: Ni odgovora.

\section{2. vprašanje: VZPON NA GORO FUDŽI}

Pohodniška pot Gotemba, ki vodi do vrha gore Fudži, je dolga približno 9 kilometrov $(\mathrm{km})$.

Pohodniki se morajo z $18 \mathrm{~km}$ dolgega pohoda vrniti do 20. ure.

Toši ocenjuje, da se na goro lahko vzpenja s povprečno hitrostjo I,5 kilometra na uro, spušča pa se dvakrat hitreje. $V$ to oceno je vključen čas za malico in počitek.

Če upoštevamo Tošijevo oceno hitrosti, kdaj se lahko najpozneje odpravi na pot, da se bo vrnil do 20. ure? 
VZPON NA GORO FUDŽI: TOČKOVANJE 2

\section{NAMEN VPRAŠANJA:}

Opis: Izračunati potreben čas na podlagi dveh danih hitrosti in skupne razdalje, ki jo je treba prehoditi

Matematično področje: Spremenljivke in odnosi

Kontekst: Družbeni

Proces: Formuliranje

Pravilen odgovor

Koda 1: Ob 11. uri [Ali vsak drug enakovreden način zapisa časa, npr. Ob 11.00.]

Nepravilen odgovor

Koda 0: Drugi odgovori.

Koda 9: Ni odgovora. 
3. vprašanje: VZPON NA GORO FUDŽI

Toši je med pohodom po poti Gotemba nosil pedometer, ki je štel njegove korake.

Pedometer je pokazal, da je Toši med vzponom naredil 22500 korakov.

Oceni povprečno dolžino Tošijevih korakov med vzponom po 9-km poti Gotemba. Odgovor podaj v centimetrih $(\mathrm{cm})$.

Odgovor: $\mathrm{cm}$

\section{VZPON NA GORO FUDŽI: TOČKOVANJE 3}

\section{NAMEN VPRAŠANJA:}

Opis: Dano dolžino v kilometrih deliti z določenim številom in izraziti količnik $\mathrm{v} \mathrm{cm}$

Matematično področje: Količine

Kontekst: Družbeni

Proces: Uporaba

Pravilen odgovor

Koda 2: 40

Delno pravilen odgovor

Koda 1: 0,4 [Odgovor je podan v metrih.]

Nepravilen odgovor

Koda 0: Drugi odgovori.

Koda 9: Ni odgovora. 
KOLESARKA HELENA

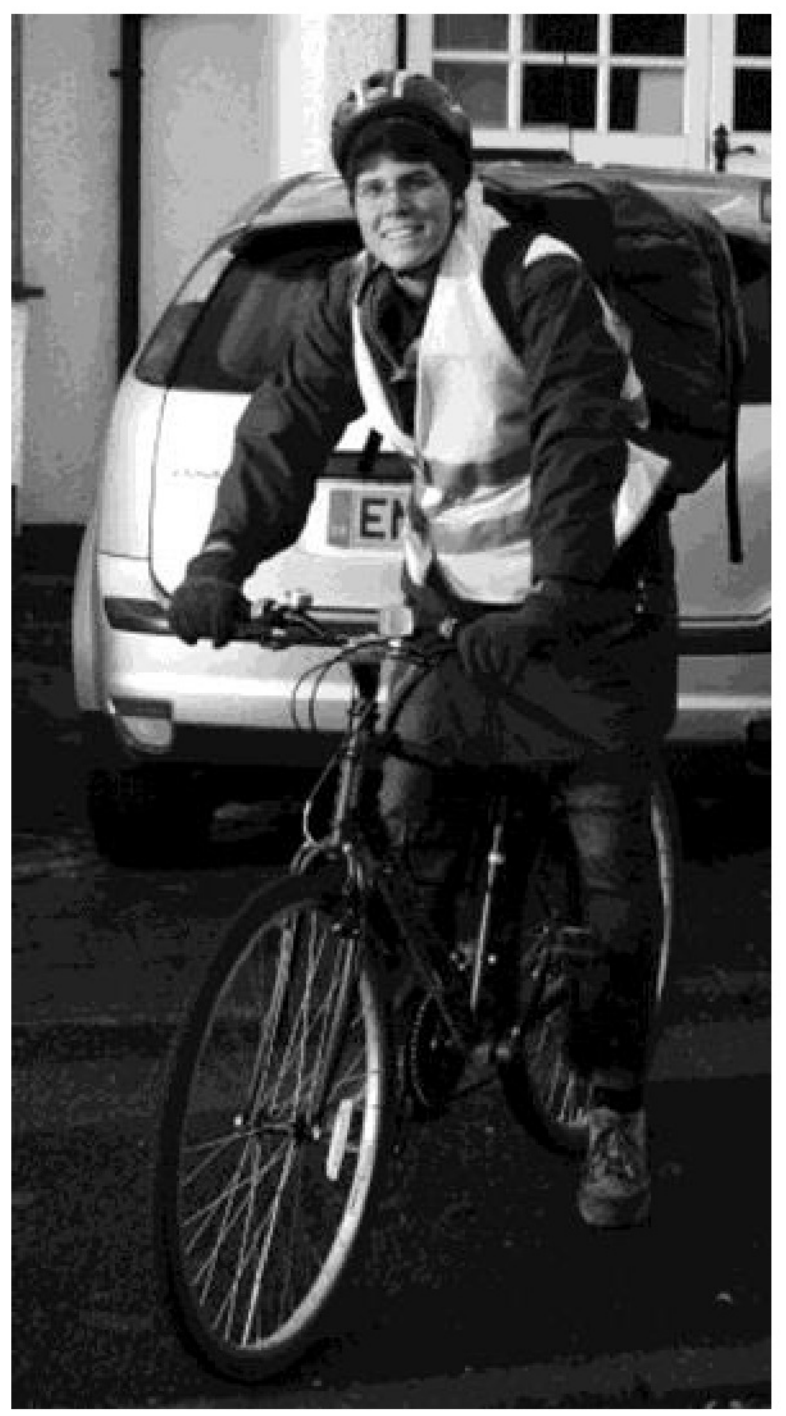

Helena je dobila novo kolo s števcem hitrosti, ki je pritrjen na krmilo.

Števec hitrosti kaže razdaljo, ki jo Helena prevozi, in povprečno hitrost njene vožnje. 
I. vprašanje: KOLESARKA HELENA

$\mathrm{Na}$ izletu je Helena v prvih o minutah prevozila $4 \mathrm{~km}$, nato pa v naslednjih 5 minutah še $2 \mathrm{~km}$.

Katera od naslednjih trditev je pravilna?

A Helenina povprečna hitrost je bila $\mathrm{v}$ prvih ıo minutah večja kot $\mathrm{v}$ naslednjih 5 minutah.

B Helenina povprečna hitrost je bila v prvih to minutah enaka kot v naslednjih 5 minutah.

C Helenina povprečna hitrost je bila v prvih ıo minutah manjša kot v naslednjih 5 minutah.

D Na podlagi danih podatkov ni mogoče reči ničesar o Helenini povprečni hitrosti.

\section{KOLESARKA HELENA: TOČKOVANJE 1}

\section{NAMEN VPRAŠANJA:}

Opis: Primerjati povprečne hitrosti ob upoštevanju prepotovane razdalje in časa Matematično področje: Spremenljivke in odnosi

Kontekst: Osebni

Proces: Uporaba

Pravilen odgovor

Koda 1: B. Helenina povprečna hitrost je bila v prvih 10 minutah enaka kot $\mathrm{v}$ naslednjih 5 minutah.

Nepravilen odgovor

Koda 0: Drugi odgovori.

Koda 9: Ni odgovora. 
2. vprašanje: KOLESARKA HELENA

Helena je prevozila $6 \mathrm{~km}$ do tetine hiše. Števec hitrosti ji je pokazal, da je bila povprečna hitrost celotne vožnje $18 \mathrm{~km} / \mathrm{h}$.

Katera od naslednjih trditev je pravilna?

Do tetine hiše je Helena potrebovala 20 minut.

Do tetine hiše je Helena potrebovala 30 minut.

Do tetine hiše je Helena potrebovala 3 ure.

Ni mogoče reči, koliko časa je Helena potrebovala do tetine hiše.

\section{KOLESARKA HELENA: TOČKOVANJE 2}

\section{NAMEN VPRAŠANJA:}

Opis: Izračunati čas potovanja ob upoštevanju povprečne hitrosti in prepotovane razdalje

Matematično področje: Spremenljivke in odnosi

Kontekst: Osebni

Proces: Uporaba

\section{Pravilen odgovor}

Koda 1: A. Do tetine hiše je Helena potrebovala 20 minut.

Nepravilen odgovor

Koda 0: Drugi odgovori.

Koda 9: Ni odgovora. 


\section{3. vprašanje: KOLESARKA HELENA}

Helena se je s kolesom peljala od doma do reke, ki je od doma oddaljena $4 \mathrm{~km}$. Do tja je potrebovala 9 minut. Domov se je peljala po bližnjici, ki je dolga $3 \mathrm{~km}$. Tokrat je potrebovala samo 6 minut.

Kolikšna je bila Helenina povprečna hitrost $(\mathrm{v} \mathrm{km} / \mathrm{h})$ med vožnjo do reke in nazaj?

Povprečna hitrost med vožnjo: $\mathrm{km} / \mathrm{h}$

\section{KOLESARKA HELENA: TOČKOVANJE 3}

\section{NAMEN VPRAŠANJA:}

Opis: Izračunati povprečno hitrosti dveh voženj na podlagi dveh prevoženih razdalj in trajanja vožnje

Matematično področje: Spremenljivke in odnosi

Kontekst: Osebni

Proces: Uporaba

Pravilen odgovor

Koda 1: 28

Nepravilen odgovor

Koda 0: Drugi odgovori.

- 28,3 [Napačna metoda: povprečje hitrosti dveh poti (26,67 in 30).]

Koda 9: Ni odgovora. 


\section{POČITNIŠKO STANOVANJE}

Kristina je na internetu našla to počitniško stanovanje, ki je naprodaj. Razmišlja, da bi ga kupila in ga oddajala turistom.

\begin{tabular}{|ll|}
\hline Število prostorov: & $\begin{array}{l}1 \mathrm{x} \text { dnevna soba } \mathrm{z} \text { jedilnico } \\
1 \mathrm{x} \text { spalnica } \\
1 \mathrm{x} \text { kopalnica }\end{array}$ \\
\hline Površina: & 60 kvadratnih metrov $\left(\mathrm{m}^{2}\right)$ \\
\hline Parkirno mesto: & $\mathrm{da}$ \\
\hline $\begin{array}{l}\text { Oddaljenost od središča } \\
\text { mesta: }\end{array}$ & 10 minut \\
\hline Oddaljenost od plaže: & 350 metrov $(\mathrm{m})$ zračne linije \\
\hline $\begin{array}{l}\text { Povprečna zasedenost s turisti } \\
\text { v zadnjih 10 letih: }\end{array}$ & 315 dni na leto \\
\hline
\end{tabular}

\section{I. vprašanje: POČITNIŠKO STANOVANJE}

Kristina je prosila strokovnjaka, da določi ceno počitniškega stanovanja. Pri ocenjevanju vrednosti počitniškega stanovanja strokovnjak upošteva naslednja merila:

\begin{tabular}{|c|c|c|c|c|c|}
\hline Cena za $\mathrm{m}^{2}$ & $\begin{array}{l}\text { Osnovna } \\
\text { cena: }\end{array}$ & $\begin{array}{l}2500 \text { zedov } \\
\mathrm{za} \mathrm{m}^{2}\end{array}$ & & & \\
\hline \multirow[t]{3}{*}{$\begin{array}{l}\text { Merila, ki } \\
\text { povečujejo } \\
\text { vrednost }\end{array}$} & $\begin{array}{l}\text { Oddaljenost } \\
\text { od središča } \\
\text { mesta: }\end{array}$ & $\begin{array}{l}\text { Več kot } 15 \\
\text { minut: } \\
+0 \text { zedov }\end{array}$ & $\begin{array}{l}\text { Od } 5 \text { do } 15 \\
\text { minut: } \\
+10000 \\
\text { zedov }\end{array}$ & $\begin{array}{l}\text { Manj kot } 5 \\
\text { minut: } \\
+20000 \\
\text { zedov }\end{array}$ & \\
\hline & $\begin{array}{l}\text { Oddaljenost } \\
\text { od plaže } \\
\text { (zračne } \\
\text { linije): }\end{array}$ & $\begin{array}{l}\text { Več kot } 2 \\
\text { km: } \\
+0 \text { zedov }\end{array}$ & $\begin{array}{l}\text { Od } 1 \text { do } 2 \\
\mathrm{~km}: \\
+5000 \text { zedov } \\
\end{array}$ & $\begin{array}{l}\text { Od } 0,5 \text { do } 1 \\
\mathrm{~km}: \\
+10000 \\
\text { zedov }\end{array}$ & $\begin{array}{l}\text { Manj kot } 0,5 \\
\mathrm{~km}: \\
+15000 \\
\text { zedov } \\
\end{array}$ \\
\hline & $\begin{array}{l}\text { Parkirno } \\
\text { mesto: }\end{array}$ & $\begin{array}{l}\text { Ne: } \\
+0 \text { zedov }\end{array}$ & $\begin{array}{l}\text { Da: } \\
+35000 \\
\text { zedov }\end{array}$ & & \\
\hline
\end{tabular}


Če je vrednost, ki jo oceni strokovnjak, višja od objavljene prodajne cene, potem je prodajna cena za Kristino kot morebitnega kupca "zelo ugodna”.

Prikaži, da je na podlagi meril strokovnjaka ponujena prodajna cena “zelo ugodna” za Kristino.

\section{POČITNIŠKO STANOVANJE: TOČKOVANJE 1 \\ NAMEN VPRAŠANJA:}

Opis: Ovrednotiti merila v primerjavi z objavljeno prodajno ceno počitniškega stanovanja

Matematično področje: Količine

Kontekst: Družbeni

Proces: Uporaba

Pravilen odgovor

Koda 1: Odgovor, ki pokaže, da je ocenjena vrednost na podlagi meril strokovnjaka 210000 zedov, kar je več kot 200000 zedov, torej je to "zelo ugodna" cena. [Strokovnjakova vrednost 210000 zedov mora biti eksplicitno podana, objavljena cena pa je labko podana implicitno ali eksplicitno.]

- Strokovnjakova skupna cena je 210000 zedov, kar je več kot objavljena cena 200000 in to pomeni, da je to zelo ugodna cena.

- Skupna cena 210000 zedov je višja kot objavljena cena.

Nepravilen odgovor

Koda 0: Drugi odgovori.

Koda 9: Ni odgovora. 
2. vprašanje: POČITNIŠKO STANOVANJE

V zadnjih ro letih je bilo stanovanje v povprečju 315 dni na leto zasedeno s turisti.

Ugotovi, ali iz tega podatka lahko izpeljemo naslednje trditve. Pri vsaki trditvi obkroži "Da" ali "Ne".

\begin{tabular}{|l|c|}
\hline \multicolumn{1}{|c|}{ Trditev } & $\begin{array}{c}\text { Ali lahko iz danega podatka izpeljemo } \\
\text { to trditev? }\end{array}$ \\
\hline $\begin{array}{l}\text { Z gotovostjo lahko trdimo, da je bilo } \\
\text { počitniško stanovanje vsaj enkrat v zadnjih } \\
10 \text { letih zasedeno s turisti točno } 315 \text { dni. }\end{array}$ & $\mathrm{Da} / \mathrm{Ne}$ \\
\hline $\begin{array}{l}\text { Teoretično je mogoče, da je bilo v zadnjih } 10 \\
\text { letih stanovanje vsako leto zasedeno s turisti } \\
\text { več kot 315 dni. }\end{array}$ & $\mathrm{Da} / \mathrm{Ne}$ \\
\hline $\begin{array}{l}\text { Teoretično je mogoče, da enkrat v } 10 \text { letih } \\
\text { stanovanje sploh ni bilo zasedeno s turisti. }\end{array}$ & $\mathrm{Da} / \mathrm{Ne}$ \\
\hline
\end{tabular}

Opomba: Upoštevaj, da ima leto 365 dni.

\section{POČITNIŠKO STANOVANJE: TOČKOVANJE 2}

\section{NAMEN VPRAŠANJA:}

Opis: Interpretirati pomen dane povprečne vrednosti

Matematično področje: Verjetnost in delo s podatki

Kontekst: Družbeni

Proces: Interpretiranje

Pravilen odgovor

Koda 1: Trije pravilni odgovori: $\mathrm{Ne}, \mathrm{Ne}, \mathrm{Da}, \mathrm{v}$ tem vrstnem redu.

Nepravilen odgovor

Koda 0: Drugi odgovori.

Koda 9: Ni odgovora. 


\section{IZPOSOJA DVD-JEV}

Julija dela v izposojevalnici DVD-jev in videoiger.

Letna članarina v izposojevalnici stane 10 zedov.

Cena izposoje DVD-ja je za člane nižja kot za nečlane, kakor je prikazano v spodnji tabeli.

\begin{tabular}{|c|c|}
\hline $\begin{array}{c}\text { Cena izposoje DVD-ja za } \\
\text { nečlane }\end{array}$ & $\begin{array}{c}\text { Cena izposoje DVD-ja za } \\
\text { člane }\end{array}$ \\
\hline $3,20 \mathrm{zeda}$ & $2,50 \mathrm{zeda}$ \\
\hline
\end{tabular}

\section{I. vprašanje: IZPOSOJA DVD-jev}

Tone je bil lani član izposojevalnice DVD-jev.

V celem letu je skupno porabil 52,50 zeda, v kar je vključena tudi letna članarina.

Koliko bi Tone porabil za izposojo istega števila DVD-jev, če ne bi bil član?

Število zedov:

IZPOSOJA DVD-jev: TOČKOVANJE 1

\section{NAMEN VPRAŠANJA:}

Opis: Izračunati in primerjati rezultate v vsakdanji situaciji

Matematično področje: Količine

Kontekst: Osebni

Proces: Uporaba 
Pravilen odgovor

Koda 1: $\quad 54,40$

Nepravilen odgovor

Koda 0: Drugi odgovori.

Koda 9: Ni odgovora.

\section{2. vprašanje: IZPOSOJA DVD-jev}

Kolikšno je najmanjše število DVD-jev, ki si jih mora član izposoditi, da pokrije stroške članarine? Zapiši svoj potek reševanja.

Število DVD-jev:

\section{IZPOSOJA DVD-jev: TOČKOVANJE 2}

NAMEN VPRAŠANJA:

Opis: Izračunati in primerjati števila v vsakdanji situaciji

Matematično področje: Količine

Kontekst: Osebni

Proces: Formuliranje

Pravilen odgovor

Koda 21: 15 [Algebraična rešitev s pravilnim sklepanjem]

- $3,20 \bullet \mathrm{x}=2,50 \bullet \mathrm{x}+10$

$0,70 \bullet \mathrm{x}=10$

$\mathrm{x}=10 \div 0,70=14,2$ približno, ampak to mora biti celo število, zato 15 DVD-jev.

- 3,20 • $\mathrm{x}>2,50 \bullet \mathrm{x}+10$ [Isti koraki kot v prejšnjem primeru, vendar $z$ uporabo neenačbe.] 
Koda 22: 15 [Računska (aritmetična) rešitev s pravilnim sklepanjem]

- Član pri enem DVD-ju prihrani 0,70 zeda. Ker je na začetku plačal 10 zedov, mora prihraniti vsaj to vsoto, da pokrije članarino. $10 \div 0,70=14,2 \ldots$ ali 15 DVD-jev.

Koda 23: 15 [Pravilna rešitev z uporabo sistematičnega poskušanja, pri kateri učenec izbere eno stevilo ter poǐčce ceno za člane in nečlane; nato te rezultate uporabi, da določi stevilo (15), pri katerem član plača manj kot nečlan.]

- 10 DVD-jev = 32 zedov za nečlane in 25 zedov +10 zedov $=35$ zedov za člane. Potrebno je poizkusiti s številom, ki je večje od 10. 15 DVDjev stane 54 zedov za nečlane in $37,50+10=47,50$ zedov za člane. Če poskusiš z manjšim številom: $14 \mathrm{DVD}$-jev $=44,80$ zedov za nečlane in $35+10=45$ zedov za člane. Torej je odgovor: 15 DVD-jev.

Koda 24: 15; s katerim drugim pravilnim postopkom reševanja.

Delno pravilen odgovor

Koda 11: 15; brez sklepanja ali postopka reševanja.

Koda 12: Pravilen izračun, a z neustreznim zaokroževanjem ali brez zaokroževanja, ker ne upošteva konteksta.

- 14

- 14,2

- 14,3

- $14,28 \ldots$

Nepravilen odgovor

Koda 00: Drugi odgovori.

Koda 99: Ni odgovora. 


\section{KABELSKA TELEVIZIJA}

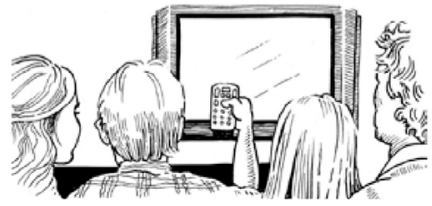

V spodnji tabeli so prikazani podatki o številu gospodinjstev, ki imajo $\mathrm{v}$ lasti televizor (TVsprejemnik), v petih državah.

Prikazan je tudi odstotek tistih gospodinjstev, ki imajo v lasti TV-sprejemnik in so naročena na kabelsko televizijo.

\begin{tabular}{|c|c|c|c|}
\hline Država & $\begin{array}{c}\text { Število } \\
\text { gospodinjstev, } \\
\text { ki imajo TV- } \\
\text { sprejemnik }\end{array}$ & $\begin{array}{c}\text { Odstotek } \\
\text { gospodinjstev, ki } \\
\text { imajo TV- } \\
\text { sprejemnik, } \\
\text { primerjavi z } \\
\text { vsemi } \\
\text { gospodinjstvi }\end{array}$ & $\begin{array}{c}\text { Odstotek gospodinjstev, ki } \\
\text { so naročena na kabelsko } \\
\text { televizijo, v primerjavi z } \\
\text { gospodinjstvi, ki imajo } \\
\text { TV-sprejemnik }\end{array}$ \\
\hline Japonska & 48,0 milijonov & $99,8 \%$ & $51,4 \%$ \\
\hline Francija & 24,5 milijona & $97,0 \%$ & $15,4 \%$ \\
\hline Belgija & 4,4 milijona & $99,0 \%$ & $91,7 \%$ \\
\hline Švica & 2,8 milijona & $85,8 \%$ & $98,0 \%$ \\
\hline Norveška & 2,0 milijona & $97,2 \%$ & $42,7 \%$ \\
\hline
\end{tabular}

Vir: ITU, Kazalci telekomunikacij v svetu 2004/2005

ITU, Poročilo o razvoju telekomunikacij/ICT v svetu 2006 
I. vprašanje: KABELSKA TELEVIZJA

V tabeli je prikazano, da ima v Švici 85,8 \% vseh gospodinjstev TV-sprejemnik.

Kolikšna je, glede na podatke v tabeli, najbližja ocena skupnega števila gospodinjstev v Švici?

2,4 milijona.

2,9 milijona.

3,3 milijona.

3,8 milijona.

KABELSKA TELEVIZIJA: TOČKOVANJE 1

NAMEN VPRAŠANJA:

Opis: V okviru danih podatkov uporabiti podatek, podan v odstotkih

Matematično področje: Verjetnost in delo s podatki

Kontekst: Družbeni

Proces: Interpretiranje

Pravilen odgovor

Koda 1: C. 3.3 milijona.

Nepravilen odgovor

Koda 0: Drugi odgovori.

Koda 9: Ni odgovora. 
2. vprašanje: KABELSKA TELEVIZJA

Klemen si v tabeli ogleda podatke za Francijo in Norveško.

Klemen pravi: "Ker je odstotek vseh gospodinjstev, ki imajo TV-sprejemnik, v obeh državah skoraj enak, ima Norveška več gospodinjstev, naročenih na kabelsko televizijo.”

Pojasni, zakaj je ta trditev nepravilna. Utemelji svoj odgovor.

\section{KABELSKA TELEVIZIJA: TOČKOVANJE 2 \\ NAMEN VPRAŠANJA:}

Opis: Razumevanje sorazmerij na osnovi podatkov, podanih v tabeli

Matematično področje: Verjetnost in delo s podatki

Kontekst: Družbeni

Proces: Interpretiranje

\section{Pravilen odgovor}

Koda 11: Odgovor, ki pravi, da bi moral Klemen upoštevati dejansko število gospodinjstev s TV-sprejemniki v obeh državah. [Namesto izraza "gospodinjstvo" je dovoljen tudi izraz "prebivalci”.

- Nima prav, ker je v Franciji približno 22 milijonov več gospodinjstev, ki imajo TV-sprejemnik.

- Ker je v Franciji približno 10-krat več prebivalcev kot na Norveškem.

- Ker ima Francija več prebivalcev, je število ljudi, ki imajo TV-sprejemnik, veliko večje, zato je večje tudi število naročnikov kabelske televizije. 
Koda12: Odgovor, ki temelji na izračunu dejanskega števila naročnikov v obeh državah.

- Ker ima Francija $(24,5 \cdot 0,154)=$ približno 3,7 milijona gospodinjstev, naročenih na kabelsko televizijo, Norveška pa jih ima (2,0 • 0,427), kar je približno 0,8 milijona gospodinjstev. Francija ima več naročnikov na kabelsko televizijo.

Nepravilen odgovor

Koda 00: Drugi odgovori.

Koda 99: Ni odgovora. 
KATERI AVTO IZBRATI?

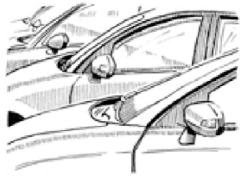

Kristina je pravkar dobila vozniško dovoljenje in želi kupiti svoj prvi avto.

V spodnji tabeli so prikazane značilnosti štirih avtomobilov, ki jih je našla pri krajevnem zastopniku avtomobilov.

\begin{tabular}{|l|c|c|c|c|}
\hline Model: & Alfa & Beta & Cita & Diva \\
\hline Leto & 2003 & 2000 & 2001 & 1999 \\
\hline $\begin{array}{l}\text { Objavljena } \\
\text { prodajna cena } \\
\text { (v zedih) }\end{array}$ & 4800 & 4450 & 4250 & 3990 \\
\hline $\begin{array}{l}\text { Prevoženi } \\
\text { kilometri } \\
\text { (v kilometrih) }\end{array}$ & 105000 & 115000 & 128000 & 109000 \\
\hline $\begin{array}{l}\text { Prostornina } \\
\text { motorja } \\
\text { (v litrih) }\end{array}$ & 1,79 & 1,796 & 1,82 & 1,783 \\
\hline
\end{tabular}


I. vprašanje: KATERI AVTO IZBRATI?

Kristina želi imeti avto, ki izpolnjuje vse naslednje pogoje:

- Nima več kot I20 o0o prevoženih kilometrov.

- Izdelan je bil leta 2000 ali v enem od naslednjih let.

- Objavljena prodajna cena ne presega 4500 zedov.

Kateri avto izpolnjuje Kristinine pogoje?
A Alfa.
B Beta.
C Cita.
D Diva.

\section{KATERI AVTO IZBRATI? TOČKOVANJE 1}

\section{NAMEN VPRAŠANJA:}

Opis: Izbrati vrednost, ki ustreza štirim numeričnim pogojem/trditvam, zastavljenim v finančnem kontekstu

Matematično področje: Verjetnost in delo s podatki

Kontekst: Osebni

Proces: Uporaba

Pravilen odgovor

Koda 1: B Beta.

Nepravilen odgovor

Koda 0: Drugi odgovori.

Koda 9: Ni odgovora. 
2. vprašanje: KATERI AVTO IZBRATI?

Kateri avto ima najmanjšo prostornino motorja?
A Alfa.
B Beta.
C Cita.
D Diva.

\section{KATERI AVTO IZBRATI? TOČKOVANJE 2}

NAMEN VPRAŠANJA:

Opis: Izbrati najmanjše decimalno število izmed štirih v danem kontekstu Matematično področje: Količine

Kontekst: Osebni

Proces: Interpretiranje

Pravilen odgovor

Koda 1: D Diva.

Nepravilen odgovor

Koda 0: Drugi odgovori.

Koda 9: Ni odgovora. 


\section{3. vprašanje: KATERI AVTO IZBRATI?}

Kristina bo morala plačati še davek, ki znaša $2,5 \%$ objavljene prodajne cene avtomobila.

Koliko znaša davek za Alfo?

Davek v zedih:

\section{KATERI AVTO IZBRATI?: TOČKOVANJE 3}

\section{NAMEN VPRAŠANJA :}

Opis: Izračunati 2,5 \% vrednosti v tisočih, v finančnem kontekstu Matematično področje: Količine

Kontekst: Osebni

Proces: Uporaba

Pravilen odgovor

Koda 1:120

Nepravilen odgovor

Koda 0: Drugi odgovori.

Koda 9: Ni odgovora. 


\section{GARA ̌̌A}

“Osnovni” program izdelovalca garaž obsega modele z enim oknom in enimi vrati.

Gorazd si je izbral spodnji model iz “osnovnega” programa. Položaj okna in vrat je prikazan spodaj.

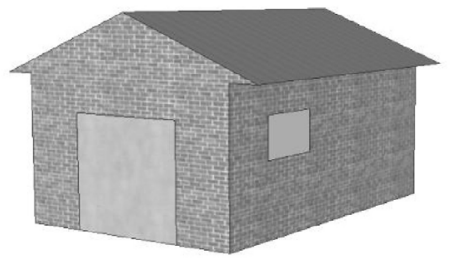

1. vprašanje: GARAŽA

Spodnje slike prikazujejo različne "osnovne" modele, gledane z zadnje strani. Samo ena slika ustreza zgornjemu modelu, ki ga je izbral Gorazd.

Kateri model je izbral Gorazd? Obkroži A, B, C ali D.

A

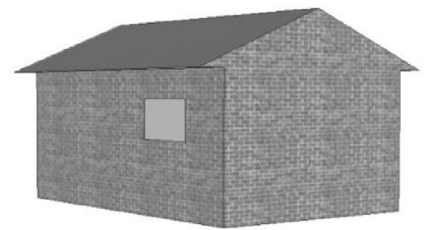

$\mathrm{C}$

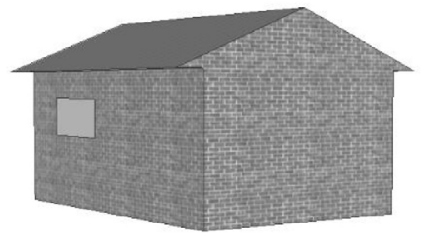

B

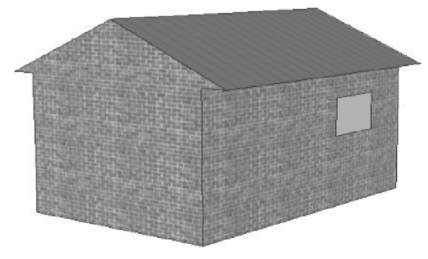

$\mathrm{D}$

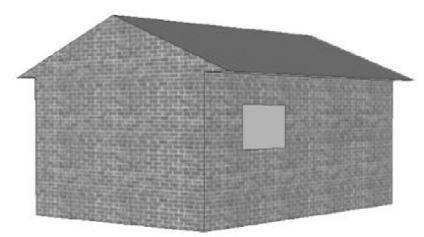


GARAŽA: TOČKOVANJE 1

\section{NAMEN VPRAŠANJA:}

Opis: Uporabiti prostorsko predstavo pri določanju ${ }_{3} \mathrm{D}$ pogleda objekat, ki se ujema z drugim ${ }_{3} \mathrm{D}$ pogledom

Matematično področje: Liki in telesa

Kontekst: Poklicni

Proces: Formuliranje

Pravilen odgovor

Koda 1: C [Slika C]

Nepravilen odgovor

Koda 0: Drugi odgovori.

Koda 9: Ni odgovora.

2. vprašanje: GARAŽA

Na spodnjih dveh načrtih so prikazane dimenzije garaže (v metrih), ki jo je izbral Gorazd.

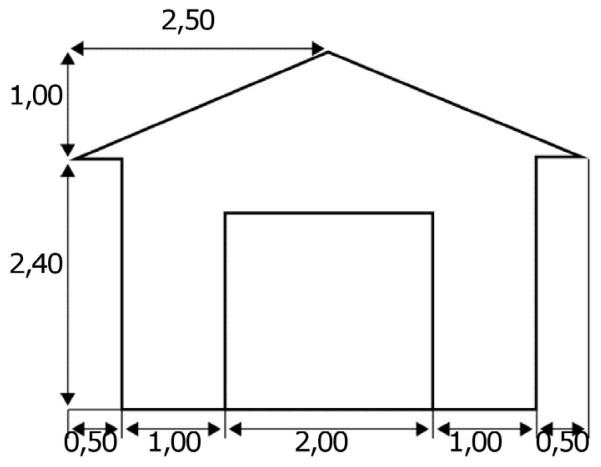

Pogled od spredaj

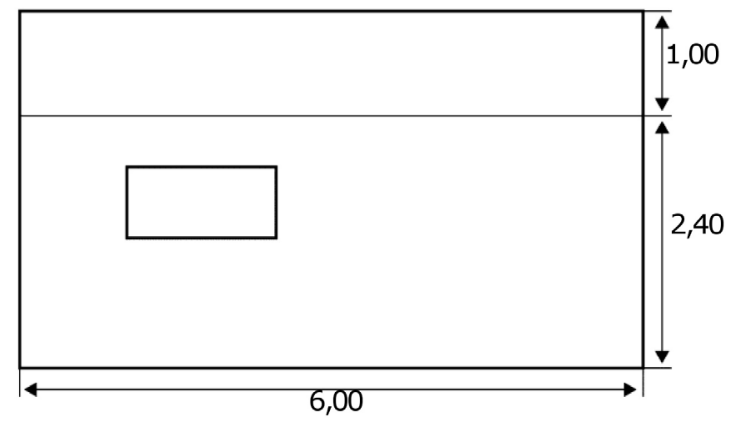

Pogled od strani

Streha je sestavljena iz dveh enakih pravokotnih ploskev. 
Izračunaj površino (ploščino) celotne strehe. Zapiši svoj potek reševanja.

\section{GARAŽA: TOČKOVANJE 2 NAMEN VPRAŠANJA:}

Opis: Uporabiti Pitagorov izrek pri tolmačenju načrta in izračunati ploščino pravokotnika

Matematično področje: Liki in telesa

Kontekst: Poklicen

Proces: Uporaba

Pravilen odgovor

Koda 21: Vsaka vrednost $\mathrm{v}$ razponu od 31 do 33 s pravilnim postopkom reševanja ali brez njega. [Enota $\left(\mathrm{m}^{2}\right)$ ni zabtevana.]

- $12 \cdot 2,6=31,2$

- $12 \sqrt{7,25} \mathrm{~m}^{2}$

- $12 \cdot 2,69=32,28 \mathrm{~m}^{2}$

- $12 \cdot 2,7=32,4 \mathrm{~m}^{2}$

Delno pravilen odgovor

Koda 11: Učenec v postopku reševanja pravilno uporabi Pitagorov izrek, vendar se bodisi zmoti pri računanju, bodisi uporabi napačno dolžino ali pa ploščine strehe ne pomnoži z dva.

- $2,5^{2}+1^{2}=6 ; 12 \cdot \sqrt{6}=29,39$ [Pravilna uporaba Pitagorovega izreka $z$ računsko napako.]

- $2^{2}+1^{2}=5 ; 2 \cdot 6 \cdot \sqrt{5}=26,8 \mathrm{~m}^{2}$ [Napačna uporaba dolžine.]

- $6 \cdot 2,6=15,6$ [Plošcine strehe ne pomnoži $z$ dva.] 
Koda 12: Učenec v postopku reševanja ne uporabi Pitagorovega izreka, vendar uporabi sprejemljivo vrednost širine strehe (vsako vrednost v razponu od 2,5 do 3 ) in pravilno izpelje račun.

- $2,5 \cdot 12=30$

- $2,55 \cdot 6 \cdot 2=30,6$

- $3 \cdot 6 \cdot 2=36$

Nepravilen odgovor

Koda 00: Drugi odgovori.

- 2,4 $12=28,8$ [Ocena širine strehe ni v sprejemljivem razponu od 2,5 do 3].

- 3,5 · 6 2 = 42 [Ocena sirine strehe ni v sprejemljivem razponu od 2,5 do 3.]

Koda 99: Ni odgovora. 


\section{PRODAJANJE ČASOPISOV}

V Zedlandiji sta dve časopisni hiši, ki iščeta prodajalce. Na spodnjih oglasih je opisano, kako svoje prodajalce plačujeta.

\begin{tabular}{||l||}
\hline \multicolumn{1}{|c||}{ ZEDLANDSKA ZVEZDA } \\
POTREBUJEŠ DODATEN \\
ZASLUŽEK? \\
PRODAJAJ NAŠ ČASOPIS \\
Plačilo: 0,20 zeda na izvod \\
za prvih 240 prodanih \\
časopisov na teden, plus \\
0,40 zeda za vsak dodatni \\
prodani izvod. \\
\end{tabular}

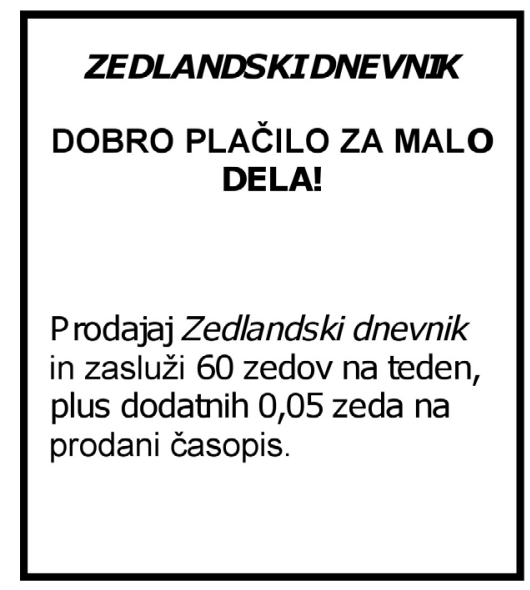


I. vprašanje: PRODAJANJE ČASOPISOV

Franci v povprečju proda 350 izvodov Zedlandske zvezde na teden.

Koliko v povprečju zasluži vsak teden?

Znesek v zedih:

PRODAJANJE ČASOPISOV: TOČKOVANJE 1

NAMEN VPRAŠANJA:

Opis: Prepoznati bistven podatek za preprost matematični model za izračun števila

Matematično področje: Spremenljivke in odnosi

Kontekst: Poklicni

Proces: Formuliranje

Pravilen odgovor

Koda 1: 92 ali 92,00.

Nepravilen odgovor

Koda 0: Drugi odgovori.

Koda 9: Ni odgovora. 
2. vprašanje: PRODAJANJE ČASOPISOV

Kristina prodaja Zedlandski dnevnik. Nekoč je v enem tednu zaslužila 74 zedov.

Koliko časopisov je prodala tisti teden?

Število prodanih časopisov:

PRODAJANJE ČASOPISOV: TOČKOVANJE 2

NAMEN VPRAŠANJA:

Opis: Prepoznati bistven podatek in ga spremeniti v preprost matematični model za izračun števila

Matematično področje: Spremenljivke in odnosi

Kontekst: Poklicni

Proces: Formuliranje

Pravilen odgovor

Koda 1: 280.

Nepravilen odgovor

Koda 0: Drugi odgovori.

Koda 9: Ni odgovora. 
3. vprašanje: PRODAJANJE ČASOPISOV

Janez se želi prijaviti za prodajalca časopisov. Izbrati mora med Zedlandsko zvezdo in Zedlandskim dnevnikom.

Kateri od spodnjih grafor pravilno prikazuje način, na katerega časopisni hiši plačujeta prodajalce? Obkroži A, B, C ali D.

PRODAJANJE ČASOPISOV: TOČKOVANJE 3

NAMEN VPRAŠANJA:

Opis: Prepoznati pravilen matematični model v primeru, ko sta dve linearni zvezi podani v obliki grafa

Matematično področje: Spremenljivke in odnosi

Kontekst: Poklicni

Proces: Interpretiranje

Pravilen odgovor

Koda 1: Graf C.

Nepravilen odgovor

Koda 0: Drugi odgovori.

Koda 9: Ni odgovora. 
A

B

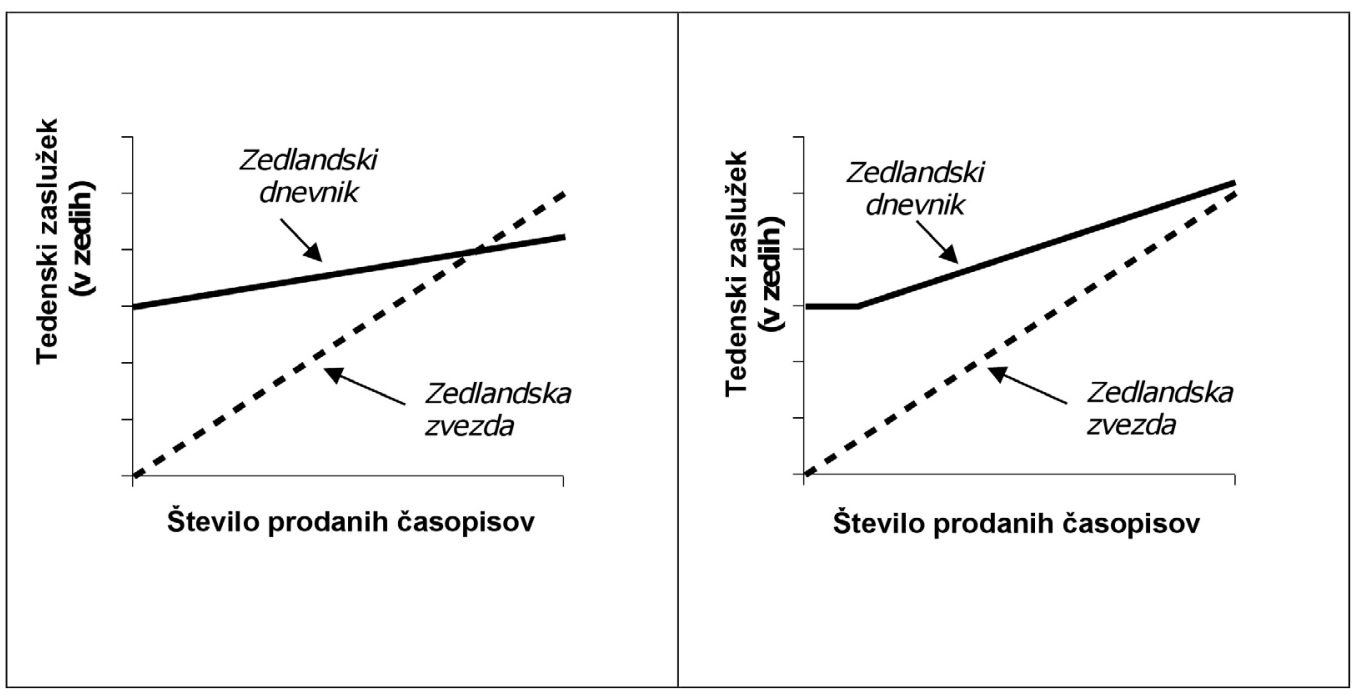

C

D

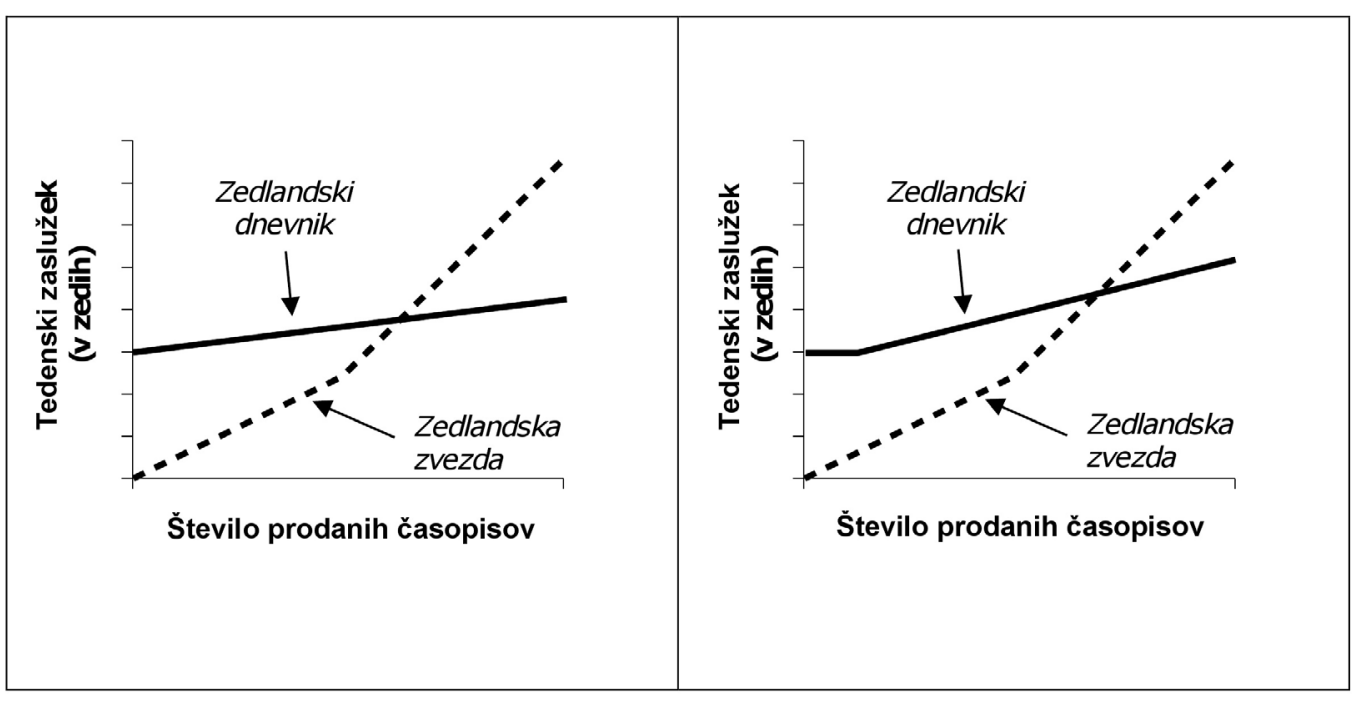




\section{VRTLJIVA VRATA}

Vrtljiva vrata so sestavljena iz treh kril, ki se vrtijo v krožnem prostoru. Notranji premer tega prostora je 2 metra (200 centimetrov). Tri vratna krila delijo prostor na tri enake dele. Spodnja

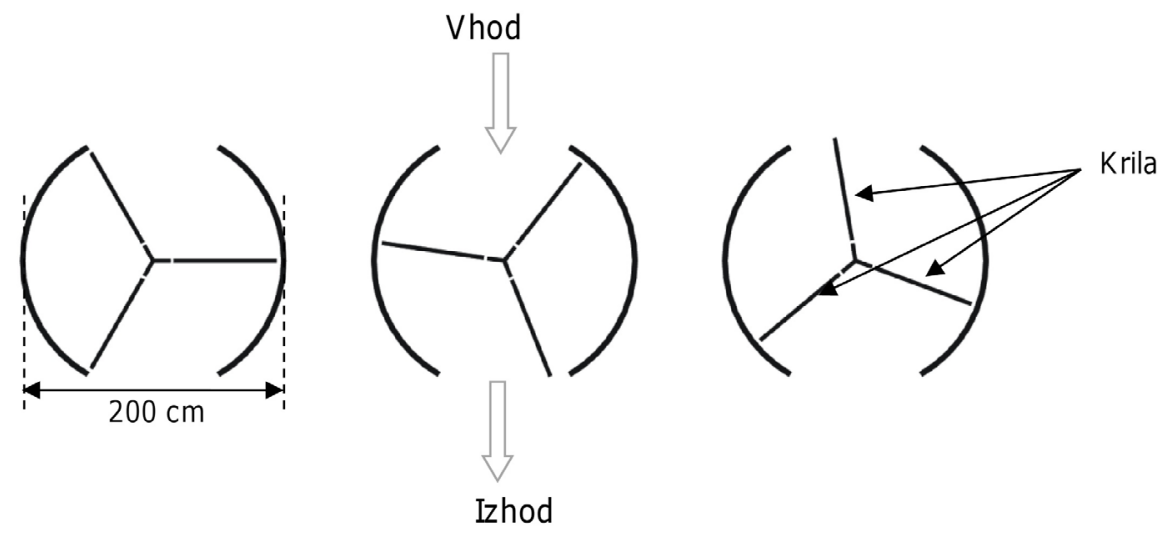

shema prikazuje vratna krila v treh različnih položajih, gledano od zgoraj. 
I. vprašanje: VRTLJIVA VRATA

Koliko stopinj meri kot med dvema vratnima kriloma?

Velikost kota:

\section{VRTLJIVA VRATA: TOČKOVANJE 1}

NAMEN VPRAŠANJA:

Opis: Izračunati središčni kot v krožnem izseku

Matematično področje: Liki in telesa

Kontekst: Znanstveni

Proces: Uporaba

Pravilen odgovor

Koda 1: 120 [sprejmite enakoureden zrcalni kot: 240].

Nepravilen odgovor

Koda 0: Drugi odgovori.

Koda 9: Ni odgovora. 
2. vprašanje: VRTLJIVA VRATA

Obe vratni odprtini (krožna loka, ki sta na shemi označena s

pikami) sta enako veliki. Če bi bili ti dve odprtini preširoki,

vrtljiva krila ne bi mogla zapreti prostora in zrak bi prosto

krožil med vhodom in izhodom, to pa bi povzročilo neželeno

izgubo ali povečanje toplote. To je prikazano v shemi na

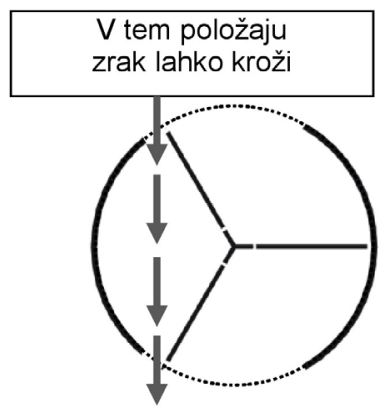

desni.

Kolikšna je največja dolžina krožnega loka v centimetrih $(\mathrm{cm})$, ki jo lahko ima vsaka

odprtina, da zrak nikoli prosto ne kroži med vhodom in izhodom?

Največja dolžina krožnega loka: $\mathrm{cm}$ 
VRTLJIVA VRATA: TOČKOVANJE 2

\section{NAMEN VPRAŠANJA:}

Opis: Interpretirati geometrijski model v realni življenjski situaciji za izračun dolžine krožnega loka

Matematično področje: Liki in telesa

Kontekst: Znanstveni

Proces: Formuliranje

Pravilen odgovor

Koda 1: Odgovori v razponu od 103 do 105. [Kot pravilen se steje odgovor $z$

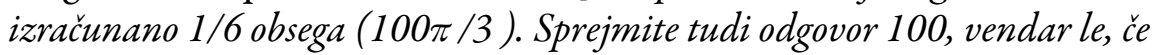
je razvidno, da je odgovor posledica uporabe $\pi=3$. Opomba: Odgovor 100 brez prikazanega postopka, ki bi odgovor podprl, je labko posledica enostavnega ugibanja, da je enak polmeru (dolžina enega krila).]

Nepravilen odgovor

Koda 0: Drugi odgovori.

- 209 [navede celotno velikost odprtin in ne velikost "vsake" odprtine].

Koda 9 Ni odgovora. 
3. vprašanje: VRTLJIVA VRATA

Vrata naredijo 4 polne obrate na minuto. V vsakem od treh delov je prostora za dve osebi.

Kolikšno je največje število oseb, ki lahko skozi vrata vstopijo v stavbo v 30 minutah?
A 60 .
B 180 .
C 240 .
D 720 .

\section{VRTLJIVA VRATA: TIČKOVANJE 5}

\section{NAMEN VPRAŠANJA:}

Opis: Prepoznati informacijo in kot rešitev problema oblikovati (impliciten) kvantitativen model

Matematično področje: Količine

Kontekst: Znanstveni

Proces: Formuliranje

Pravilen odgovor

Koda 1: D. 720.

Nepravilen odgovor

Koda 0: Drugi odgovori.

Koda 9: Ni odgovora. 


\section{Povzetek}

$\mathrm{V}$ pričujoči publikaciji predstavljamo izhodišča merjenja matematične pismenosti $\mathrm{v}$ raziskavi PISA 20I2, s primeri nalog, ki so bili uporabljeni tako v predraziskavi kot v glavnem zajemu podatkov omenjene študije. Na začetku na kratko predstavljamo organizacijske značilnosti raziskave na mednarodni in nacionalni ravni. V nadaljevanju podrobneje predstavljamo strokovna izhodišča merjenja matematične pismenosti, na podlagi katerih so oblikovane naloge. Podrobneje predstavimo tri temeljne dimenzije, in sicer matematične vsebine (spremenljivke in odnosi, količine, verjetnost in delo s podatki, liki in telesa), procese (interpretiranje, uporaba, formuliranje) ter kontekste (družbeni, poklicni, osebni in znanstveni). V naslednji poglavjih predstavljamo tudi nekatere motivacijske dejavnike matematične pismenosti ter vprašalnik za dijakinje in dijake, $s$ pomočjo katerega jih ugotavljamo. Ker je poglaviten cilj pričujoče publikacije raba le-te pri približevanju uporabe znanja v konkretnih problemsko zasnovanih situacijah učencem in dijakom, ob koncu navajamo še konkretne naloge, ki so bile s tega področja objavljene s strani organizacije OECD. Naloge zajemajo tako (stimulus) uvodno besedilo kot vprašanja ter kodirno shemo za ugotavljanje pravilnih in napačnih odgovorov. 



\section{Summary}

In this publication, we present the framework for measuring mathematical literacy in PISA 2012, with examples of units that were used in the field trial and main study of the survey. At the beginning we briefly present the organizational characteristics of research at the international and national levels. Further, we present the framework of measuring mathematical literacy, on the basis of which the units are formed. In more detail, we present three basic dimensions, namely the mathematical content areas (change and relationship, quantity, uncertainty, space and shape) processes (interpret, employ, formulate) and contexts (societal, occupational, personal and scientific). In the chapters that follow, we also present some motivational factors of mathematical literacy and the Student questionnaire, which helps us identify thee. Because the primary objective of this publication is in showing students how to use their knowledge in concrete, problem-based situations, there are concrete units at the end, which were published by the OECD. Units include stimulus, a question and also a coding guide which will help you determine right and wrong answers. 



\section{Literatura}

Blum, W., Galbraith, P., Henn in H., Niss, M. (2007). Modelling and Application in Mathematics Education, the 14th ICMI Study, by Blum, W; Galbraith, P; Henn, H; and Niss, M. International Commission on Mathematical Instruction. New York: Springer Science and Business Media.

Devlin, K. (1994). Mathematics: The science of patterns: The search for order in life, mind and the universe. United States: W. H. Freeman Scientific American Library.

Moore, D. (1997). New pedagogy and new content: The case of statistics. International Statistics Review, 65, 123-165.

NCTM (2000). Principles and standards for school mathematics. National curriculum (2007). London, United Kingdom: Qualifications and Curriculum Authority. Dostopno na spletni strani: http://standards.nctm.org.

Niss, M. (2003). Mathematical competencies and the learning of mathematics: The danish KOM Project. V Gagatsis, A. in Papastavridis, S. (ur.), 3rd Mediterranean Conference on Mathematics Education (str. 115-124). Athens, Greece: The Hellenic Mathematical Society and Cyprus Mathematical Society.

Niss, M. in Jensen, T.H. (2002). Kompetencer og matematiklering. Ideer og inspiration til udvikling af matematikundervisning i Danmark. Uddannelsesstyrelsens temahæfteserie nr. 18. Copenhagen: Ministry of Education.

OECD. (2006). PISA 2006: Science competencies for tomorrow's world. Paris: OECD.

OECD. (izide decembra, 2013). PISA 2012 results. Paris: OECD.

Repež, M., Drobnič Vidic, A. in Štraus, M. (ur.) (2008). Izhodišča merjenja matematične pismenosti v raziskavi PISA 2006. Ljubljana: Pedagoški inštitut. 
Steen, L. (1990). On the shoulders of giants: New approaches to numeracy. Washington, D.C.: National Academy Press.

Štraus, M. (ur.) (2008). Program mednarodne primerjave dosežkov učencev PISA: zbornik prispevkov o metodoloških vidikih raziskave PISA, 1. izd. Ljubljana: Pedagoški inštitut.

Thomson, S. in Hillman, K. (2010). Against the odds: Influences on the post-school success of 'low performers'. Adelaide, Australia: NCVER.

Turner, R. (2009). PISA: An Introduction and Overview. V W. Rodger in J. Arlington (ur.), PISA Science 2006: Implications for Science Teachers and Teaching (str. 3-13). Virginia: NSTA Press.

Turner, R. (2011). Using mathematical competencies to predict item difficulty in PISA: A MEG study 2003-2009. Proceedings of the PISA Research Conference, Kiel 2011.

Watson, J. M. in Callingham, R. (2003). Statistical literacy: A complex hierarchical construct. Statistics Education Research Journal, 2, 3-46. 


\section{Imensko in stvarno kazalo}

B

Blum, W. 31

C

Callingham, R. 45

definicija matematične pismenosti 28

Devlin, K. 34

$\mathrm{H}$

Hillman, K. 57

1

interpretiranje matematičnih situacij 20 ,

$25,30,31,37,38,43,44,45,46,48,49$

J

Jensen, T. H. 44

K

količine $25,37,38,40,106$
L

lestvica matematičnih dosežkov 24

liki in telesa 25

M

matematična orodja 29,48

matematična pismenost 20

Matematična pismenost $28,37,45,46$

matematične vsebine 20,34

matematični kontekst 30, 51

matematični problem 30

matematični procesi 40

matematično formuliranje $25,28,30,40$,

$41,42,45,54$

Moore, D. 38

N

Nacionalni center raziskave PISA 18

naloge iz matematične pismenosti 59

NCTM 44

Niss, M. 44 


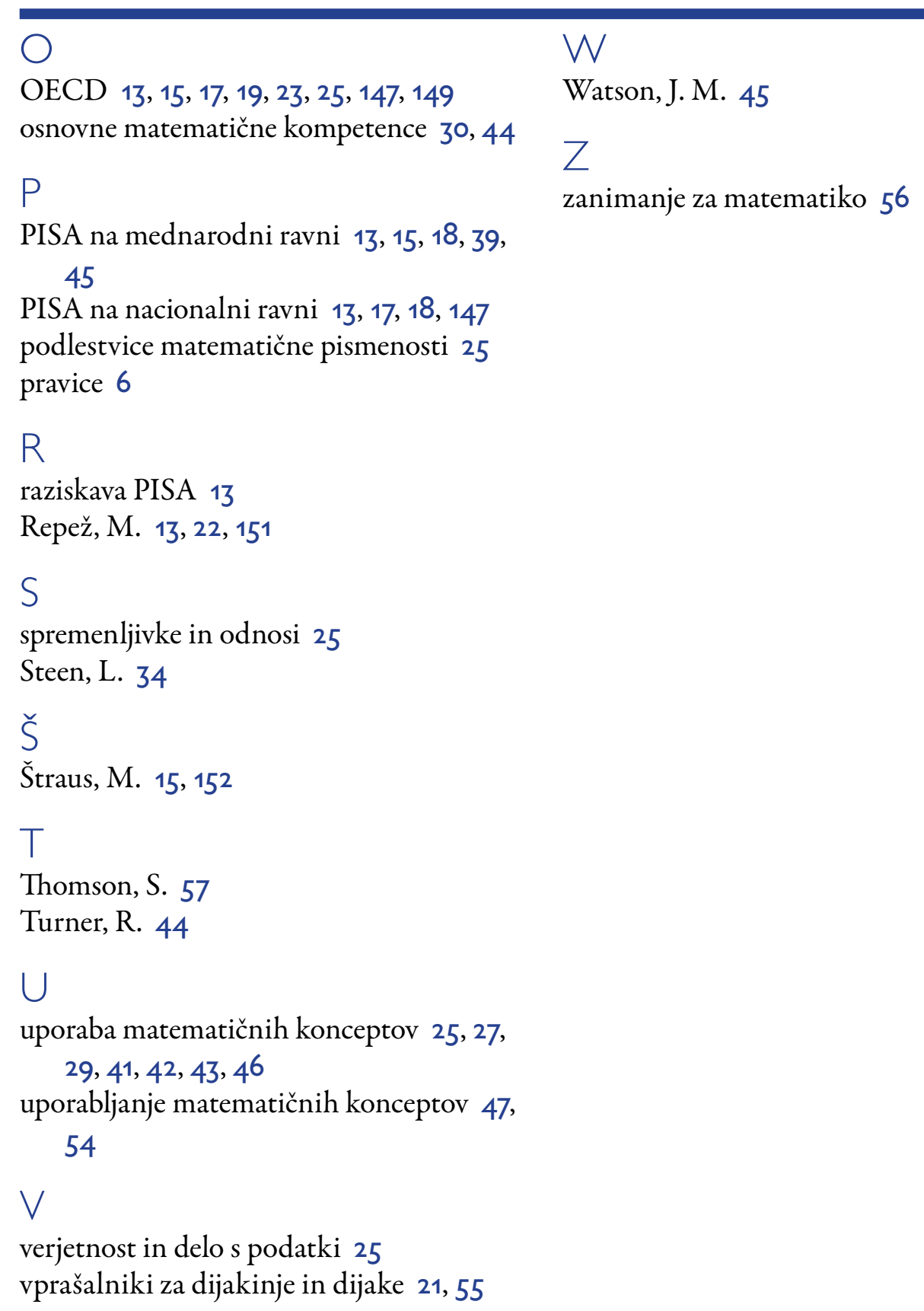

zanimanje za matematiko 56 



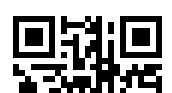 . 吕的}

